\title{
Davranış Teorilerinin Bireysel, Sosyal ve Normatif Açıdan Kavramlaştırılması: BSN Davranış Modeli Önerisi
}

\author{
Işıl Mendeş Pekdemir ${ }^{1}$ (1) Aygül Dönmez Turan²
}

Öz

Birey davranışlarının irdelenmesi ve anlamlandırılması milattan önceki çağlara kadar uzanmasına ve ilkçağda yaşamış birçok filazofun düşünce akımlarında birey ve toplum davranışları ile ilgili incelemeler bulunmasına rağmen; endüstriyel psikoloji çerçevesinde birey davranışlarının örgüt bağlamında analiz edilmesi 19. yüzyılın sonlarına rastlamaktadır. Birey davranışlarının toplum veya daha sınırlı bir topluluk olan örgüt yönetiminde ne kadar önemli olduğu anlaşılmasıyla, gerek psikoloji gerek sosyoloji gerekse endüstriyel psikoloji alanlarında birey davranışlarını açıklayan birçok teori ve yaklaşım geliştirilmiştir. Bu teori ve yaklaşımlar farklı kapsam/bağlamlarda, belirli yönleriyle birbirini doğrulayan, belirli yönleriyle birbirinden ayrılan modeller sunmuştur. illgili teori, yaklaşım ve modelleri bir çat altında toplamak ve davranışın yapısını ortaya koyacak bir model oluşturmak amacıyla; üç aşamada gerçekleştirilen bu çalışmanın birinci aşamasında, birey davranışını farklı çerçevelerde değerlendiren 12 davranış teorisinin farklı bir bakış açısıyla incelenmesi sonucunda, birey davranışlarında yeni bir gruplamaya gitme ihtiyacı ortaya konulmuş ve birey davranışları bireysel, sosyal ve normatif açıdan üç ana kategoride gruplandırılmıştır. Bu gruplandırmanın ardından çalışmamızın ikinci aşamasında davranışları açıklayan, literatürde kabul görmüş 26 davranış teori, yaklaşım ve model, bireyin bireysel, sosyal ve normatif açıdan sergilediği davranışlar açısından incelenmiş ve bu davranışlar kavramsal bir çerçeveye oturtulmuştur. Üç grupta topladığımız bireyin davranışlarını açıklayan bir model önerisi geliştirmek bu çalışmanın temel motivasyonunu oluşturmuştur. Bu amaçla, çalışmamızın üçüncü aşamasında da, literatürde ilgili teoriler ve modeller ışığında bu üç grup birey davranışını açıklayan bir model, BSN Davranış Modeli (Bireysel, Sosyal ve Normatif Davranış Modeli) önerilmiştir.

\section{Anahtar Kelimeler}

Davranış teorilerinin kavramlaştrııması • Teorik model önerisi • BSN davranış modeli (Bireysel, Sosyal ve Normatif Davranış Modeli)

\section{Conceptualization of Behavioral Theories on the Basis of Individual, Social and Normative Perspective: ISN} Behavioral Model Proposal

Abstract

On the industrial psychology framework, investigating human behavior in the organizational context dates from the $19^{\text {th }}$ century. However, evaluations of individual and social behaviors trace back to the quotes of ancient philosophers, so considering and sensemaking the human behavior dates from the ancient age. Understanding the importance of human behavior in management of organizations as well as society, many different theories and approaches were developed in order to explain human behavior in the literature over the decades. The theories and approaches purposed specific models, and then some subsequent researches confirmed to previous models, but a number of other researches developed new models distinct from the formers. In order to illuminate the confusion of behavioral theories, approaches and models, we aimed to explore whether these theories, approaches and models could be gathered in different perspective in this study paper. Thus we developed a model to indicate the construction of behavior in three phases. In the first phase, 12 main behavioral theories, approaches and models evaluated human behavior on the different frameworks were examined from a unique/distinct points of view. Then present researchers identified the needs to develop a new classification for human behavior as individual, social and normative. In the second phase, other 26 behavioral theories, approaches and models in the literature were investigated in terms of individual, social as well as normative perspectives of behavior exhibited by human, and these behaviors were conceptualized. On that point, the main motivation of this study is to develop a model explaining the human behaviors which were classified into three groups mentioned. Accordingly, in the last phase of our study, Individual, Social and Normative (PSN) Behavioral Model which explains the three perspectives of the human behavior has been purposed on the basis of the theories as well as approaches in the literature.

\section{Keywords}

Conceptualization of behavioral theories • Theoretical model oroposal • ISN behavioral model (Individual, Social and Normative Behavioral Model)

1 Işıl Mendeş Pekdemir (Prof. Dr.), İstanbul Üniversitesi, İşletme Fakültesi, İşletme Yönetimi ve Organizasyonu Ana Bilim Dalı, İstanbul, Türkiye. E-posta: isilmp@istanbul.edu.tr

2 Sorumlu Yazar: Aygül Dönmez Turan (Dr. Öğr. Üyesi), Yıldız Teknik Üniversitesi, İktisadi ve İdari Bilimler Fakültesi,

Örgütsel Davranış Ana Bilim Dalı, İstanbul, Türkiye. E-posta: ayturan@yildiz.edu.tr

Atıf: Mendeş-Pekdemir, I. ve Dönmez-Turan, A. (2018). Davranış teorilerinin bireysel sosyal ve normatif açıdan

kavramlaştırılması: BSN davranış modeli. Istanbul Management Journal, 29(85), 127-186.

http://dx.doi.org/10.26650/imj.2018.29.85.0010 


\section{Extended Summary}

\section{Background}

Understanding the significance or materiality of human behaviors in management in organizations and societies has become important. For this, over the decades, many different theories and approaches were developed to explain human behaviors in the literature. Earlier studies proposed specific models. Some subsequent researches confirmed previous models, whereas others led to the development of new models, different from the former ones.

\section{Purpose}

To clarify the confusion of behavioral theories, approaches, and models, this study aims to explore whether these theories, approaches, and models could be distinguished from each other based on their similarities and differences, and whether they could be categorized into different classes. To achieve this, the behavioral theories were analyzed in detail, and a model was developed to demonstrate the construction of behavior.

\section{Methodology}

Following this study's aim, the present researchers realized a three-phase model development process, which laid the groundwork for the exploration of the behavioral theories and development of the proposed model.

In the first phase (making decision to categorize human behaviors), 12 behavioral theories, approaches and models evaluating human behaviors on the different frameworks were examined from a unique and distinct perspective. This phase comprised determining the scope of behavior, based on the logic behind field theory, attitude- behavior-context theory, MARS model, intrinsic/extrinsic, learning theories [classical, operant (conditioning), cognitive, and social (social cognitive theory)], social exchange theory, idealism, rational choice, and against rational choice approach. Investigating these theories in detail, we obtained three main categories into which aspects of human behavior can be distinguished: individual, social, and normative. Then, the researchers identified the need to develop a new classification model for human behaviors based on these aspects.

In the second phase (investigating behavioral theories, approaches, and models in terms of individual, social and normative dimensions of behavior), other 26 behavioral theories, approaches, and models in the literature were investigated based on the individual, social, and normative perspectives of behaviors exhibited by humans. These include the ecological value theory, simple expectancy-value- 
attitude theory, theory of reasoned action, theory of planned behavior, symbolic self completion theory, self-perception theory, cognitive dissonance theory, focus theory of normative conduct, social symbolic self theory, self-discrepancy theory, social identity theory, cultural theory, value belief norm theory, norm action model, cognitive effort-control, automaticity and heuristics, environmental self-identity, theory of interpersonal behavior, the motivation-opportunity-ability model, structuration theory, framing, priming and biasing approach, prosocial behavior, helping behavior, organizational citizenship behavior, voice behavior, organizational citizenship behavior for environment, and ethical behavior. Obtaining implications from these behavioral theories, approaches, and models, present researchers supported their claim by categorizing them under the three classes mentioned in the first phase. After elaborating on each behavioral theory, approach, and model regarding the individual, social, and normative perspective of human behaviors, we conceptualized the three different behaviors with their dimensions.

The main motivation behind the study was to develop a model explaining the human behaviors, which are classified into three main groups mentioned. Accordingly, in the last phase (model proposal) of this study, the individual, social, and normative (ISN) behavioral model, which explains the three perspectives of the human behavior, has been proposed based on the theories and approaches in the literature.

\section{Conclusion}

The individual aspect of behavior was defined for this study as behaviors, wherein one engages after making a cost-benefit analysis at an individual level sometimes. The rationale behind their individual behaviors could be that they want to acquire either monetary or spiritual gains, or they take pleasure or enjoy doing the act, feel content while doing or not doing them, or they have learned or have even developed a habit of doing them routinely.

The social aspect of behavior was defined for this study as behaviors one displays after making a cost-benefit analysis at a social level to be valued and accepted by others, avoid social exclusion, enjoy social conformity, expect something in return, or drive social benefits.

The normative aspect of behavior was defined as voluntary or idealist behaviors one shows when they act in line with their own correct principles and norms, consider the goodness and welfare of all living entities, evaluate events on moral grounds, and make a cost-benefit analysis on a normative level in the long-run.

Following our own definition, we assert that the individual dimension of behavior comprises "personal cost-benefit (personal interest)", "emotional responses/ 
drives", and "habits/routines"; the social dimension comprises "social cost-benefit (social interest)", "reciprocity", "acceptance", and "conformity"; and the normative dimension consists of "normative cost-benefit (long term interest)", "welfare of all living entities", "altruism", "voluntarism", and "idealism".

Based on the definition of ISN (individual, social, and normative) dimensions of behavior, we proposed a theoretical model developed from the elements of behavioral theories evaluated in the previous phases. The proposed model represented the link from attitude to behavior, which confirmed a number of research findings in organizational behavior literature. Furthermore, other researchers mentioned that goals acted as the mediator in the relationship between attitude and behavior, while conditions/situations acted as the moderator in this relationship. On the other hand, organizational behavior researches showed personal values related to the behavior of individuals. However, individuals do not always behave in line with their values because some situations do not favor following individual values. Apart from behaving in accordance with personal values, the researchers explained that humans behave in accordance with their goals. In this case, individuals have to be motivated to achieve their goals. Following these researchers, we propose the following theoretical model illustrated in Figure 1.

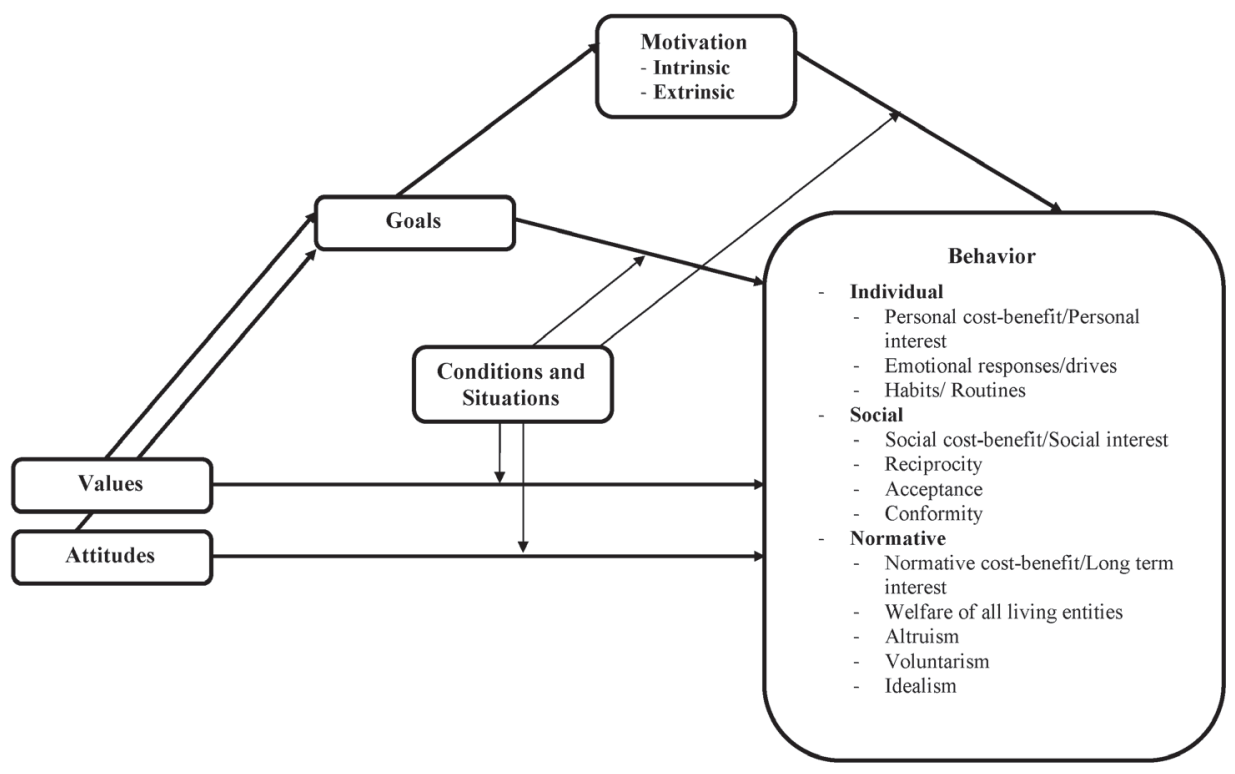

Figure 1: INDIVIDUAL, SOCIAL, AND NORMATIVE (ISN) BEHAVIORAL MODEL 
Psikoloji, sosyoloji ve örgütsel psikoloji araştırmalarının çoğu deneysel çalışmalarla başlamıştır. Günümüze kadar gelmiş ve literatürde kabul görmüş çoğu teori, daha sonra hem deneysel hem de başka yöntemlerle yapılan çalışmalarla desteklenmiştir. 1927 yılında Pavlov'un köpekler üzerinde yaptığı deney ${ }^{1}$, bireylerin klasik koşullanma ile; Skinner'in (1948) güvercinler üzerinde yaptığı deney, bireylerin edimsel koşullanma (ödül/ceza) ile öğrendiğinin temelini atan çalışmalar olmuştur. Burada klasik ve edimsel koşullanma; bireyin daha önceden benimsediği tutumlar ve değer yargıları ile sahip olduğu alışkanlıkları doğrultusunda hareket etmesine göre, veya hangi davranışlarının ödül hangilerinin ceza ile sonuçlanacağına (önceden öğrenilenler, alışkanlık haline getirilenler, amaçlara ulaştıracak hareketler) göre davranışlarını düzenlemesini izah etmektedir (Schultz ve Schultz, 2001). Koşullanmanın yanında bireylerin düşünerek ve bilişsel/zihinsel süreçleri yardımıyla öğrendiği ise Tolman'ın (1951) labirent üzerinde yaptığg fare deneyleri temel alınarak açıklanır. Bilişsel öğrenme olarak bilinen bu teori ise, bireyin sadece koşullanarak değil, zihninde gerçekleştirdiği belirli analizler (fayda-maliyet, neyin doğru neyin yanlış olduğu) sonucunda davranışlarını düzenlediğini açıklanmaktadır (Şimşek, Çelik ve Akgemci, 2015). Bu öğrenme şekillerine ek olarak Bandura (1989), bobo oyuncağı deneyi ile bebeklerin sosyal olarak nasıl öğrendiğini göstermiştir. Sosyal bilişsel teori olarak adlandırılan bu teori de, bireylerin davranışlarını bulundukları sosyal ortamdan etkilenerek sergilediğini iddia etmektedir (Myers, 2015). Yine bilişsel teoride bahsi geçen zihinsel analizler söz konusudur ancak buradaki analiz sosyal bağlamdaki fayda-maliyet analizleri çerçevesinde değerlendirilebilecek bir analizdir.

Bahsi geçen herbir öğrenme deneyi ilerleyen y1llarda birçok araştırma ile doğrulanmış, birçok araştırmacı tarafından eklemeler yapılarak daha da genişletilmiştir. Birey davranışlarını açıklamada temel olarak görülen öğrenme teorilerinden (Şimşek vd., 2015) sonra, yine birçok araştırmacı birey davranışlarının farklı bir tarafını ele alarak davranış literatürüne farklı teori, yaklaşım ve modeller kazandırmıştır. Hatta bireyi belirli bir davranışa yönlendirme konusunda, örgüt düzeyinde öğrenme temelli bazı motivasyon teorileri geliştirilmiştir (Robbins ve Judge, 2013). Davranış literatüründe yapılan bu çalışmalar birey davranışlarını açıklamada yazına zenginlik katmış olmasına rağmen, davranışı açıklamada bir sistematikten uzaklaşılmasına neden olmuştur. Buna bir çözüm getirmek amacıyla çalışmamızda, birey davranışlarına açıklama getiren 12 ayrı teorinin, çıkış noktaları da dikkate alınarak, sistematik bir gruplandırma yapılabileceği fikri ile, öncelikle temel davranış teorileri kapsamında bir inceleme yapılmıştır. $\mathrm{Bu}$ incelemede birey davranışlarının; bireysel, sosyal ve normatif kapsamda incelenebileceği tespit edildikten sonra, literatürde kabul

1 Pavlov'un köpekler üzerinde yaptığı kasik koşullanma deneyi, 1977 yılında Watson tarafından 8 aylık bir bebek üzerinde denenmiş ve sonuçları doğrulanmıştır. 
görmüş (daha spesifik) 26 ayrı davranış teori, yaklaşım ve modeli bu üç grup temel alınarak analiz edilmiş ve birey davranışının bireysel, sosyal ve normatif boyutları tanımlanmıştır. Son olarak çalışmamız kapsamında incelenen, gerek temel davranış teorileri gerekse bu temel teorilerin geliştirilmesiyle elde edilen teoriler çerçeveside birey davranışının bireysel, sosyal ve normatif boyutlarını açıklayan Bireysel, Sosyal ve Normatif Davranış (BSN Davranış) Modeli olarak adlandırılan kavramsal bir model geliştirilmiştir.

\section{Araştımanın Amacı, Yöntemi ve Tasarımı}

Birey davranışları ve nedenlerinin açıklanması, bu alanda çalışanların dikkatini çeken konular arasında yer almış ve düşünürler kendi birikim ve görüşleri doğrultusunda birçok teori ve model geliştirmiştir. $\mathrm{Bu}$ teoriler arasında birey davranışlarını ele alma açısından ortak noktalar olduğu kadar, farklı açılardan da birey davranışlarını inceleyen teoriler mevcuttur. Bu çalışmamızda, farklı bakış açılarıyla birey davranışlarını inceleyen davranış teori, yaklaşım ve modellerini inceleyerek, ortak oldukları ve farklılaştıkları hususları ortaya koyabilir miyiz, kısaca bu teorileri tek bir çatı/yapı altında toplayabilirmiyiz sorusundan yola çıkarak ve bu doğrultuda teori, yaklaşım ve modellerin ayrıntılı bir analizini yaparak, birey davranışlarını yeniden gruplayarak davranışın yapısını ortaya koyma ve buna bağlı olarak da bir model oluşturma çabası güdülmüştür.

Çalışmamızın amacı doğrultusunda, davranışın yapısını oluşturmada temel oluşturabileceğini düşündüğümüz, model oluşturma süreci üç aşamada gerçekleştirilmiştir:

Birinci (birey davranışlarının gruplandırılması kararı) aşama, farklı bakış açılarıyla birey davranışlarını inceleyen teori, yaklaşım ve modellerin ortak oldukları ve farklılaştıkları hususlar ortaya konulabilir mi, bu teoriler tek bir çatı altında toplanabilir mi sorusuna cevap alabilmek için; ilk önce 12 temel davranış teorisinden yararlanarak birey davranışlarının yeni bir gruplamaya tabi tutulup tutulamayacağı araştırılmıştır. Bu doğrultuda bu aşama; Alan kuramı (Lewin, 1951), Tutum davranış bağlam teorisi (Stern, 2000), Mars modeli (McShane ve Von Glinow, 2016), içsel/ dışsal motivasyon (Robbins ve Judge, 2013; Şimşek vd., 2015), öğrenme teorileri [klasik, edimsel, bilişsel, sosyal (sosyal bilişsel teori)] (Pavlov, 1927;, Skinner, 1948; Tolman, 1951, Bandura, 1989) sosyal mübadele teorisi (Blau, 1964), idealism (Forsyth, 1992), rasyonel seçim teorisi (Elster 1986, Homans 1961) ve rasyonellik karşıtı görüşler (Simon, 1957; Tversky ve Kahneman, 1974; Zey, 1992; Etzioni, 1988; 1999) temel alınarak birey davranışlarının gruplandırılması ve kapsamının belirlenmesi aşamasını oluşturmaktadır. Bu görüşler doğrultusunda, birey davranışları bireysel, sosyal ve normatif boyutta gruplanabileceği kararı verilmiştir. 
İkinci aşamada (davranışların bireysel, sosyal ve normatif boyutu açısından teori, yaklaşım ve modellerin incelenmesi), birey davranışlarını açıklamak ve anlamlandırmak amacıyla, literatürde kabul görmüş çeşitli perspektiflerde birey davranışlarını değerlendiren 26 davranış teori, yaklaşım ve modeli ayrıntılı analiz edilmiş ve davranışın; bireysel, sosyal ve normatif yönünü içerecek şekilde, birey davranışları üç ayrı kategoriye indirgenmiştir. Sınırları çizilen bu çerçevede, birey davranışlarının bireysel, sosyal ve normatif boyutları kavramsallaştırılmış ve tanımlanmıştır. Özellikle bu boyutları oluşturan alt boyutların ortaya koyulmasıyla birlikte kavramsallaştırma basamağı tamamlanmıştır ve birey davranışlarınn bireysel, sosyal ve normatif boyutta gerçekleşttiği ortaya konulmuştur.

Araştırmamızın üçüncü aşamasında (model önerisi) ise, üç ayrı bakış açısıyla incelenen teori, yaklaşım ve modellerde bulunan ve davranışı açıklayan diğer değişkenler dikkate alınarak Bireysel, Sosyal ve Normatif Davranış (BSN Davranış) Modeli olarak adlandırılan kavramsal bir model oluşturulmuştur. Bu model birey davranışlarının bireysel, sosyal ve normatif boyutunu açıklayacak değişkenlerin bir arada değerlendirildiği teorik bir modeldir.

\section{Birey Davranışlarının Gruplandırılması Kararı: Teorik Çerçeve}

Davranış bir organizmanın bir ortamdaki hareket tarzı, belirli bir uyarıcıya karşı gösterdiği tepki şeklinde tanımlanmaktadır (Pavlov 1941, Eroğlu, 1997). Davranış insanların bütün eylemlerini (etki ve tepkilerini) kapsar dolayısıyla davranış insanların tek tek veya toplu olarak gösterdikleri faaliyetlerdir. Ayrıca davranış eylemi nedenli, güdülü ve amaca yöneliktir, içerisinde rastgelelik ile nedensizlik barındırmaz (Kolasa, 1979). Psikolojinin temel konusunu oluşturan birey davranışları çok nedenli ve karmaşıktır. Davranış açısından her olayın ondan önce gelen bir takım koşulların sonucu olduğu bir gerçektir (Şimşek vd., 2015). Dolayısıyla bu koşullar kişiden kişiye durumdan duruma değişeceğinden bireylerin davranışlarında da farklılıklar gözlemlenebilecektir.

Lewin (1951) fizikteki alan kavramından (manyetik, çekim alanı) yola çıkarak psikoloji temelinde alan (yaşam alanı) teorisini (field theory) ortaya atmıştır. Burada Lewin, bireyin karşılaştığı durumlar sonucunda belirli bir davranışı sergilediği ve bunun belirli bir psikolojik alanda gerçekleştiğinden bahsetmektedir. Psikolojik alan veya yaşam alanı olarak isimlendirdiği bu alan birey ve bireyin içinde bulunduğu çevreden oluşmaktadır. Yaşam alanını birey(B) ve çevrenin(Ç) etkileşimi ile oluştuğunu söylerken, birey davranışlarının(D) ise yaşam alanının(YA) bir fonksiyonu olarak tanımlamaktadır $[\mathrm{D}=f(\mathrm{YA})=f(\mathrm{~B}, \mathrm{C})]$. Lewin (1951) alan teorisinde (field theory) birey davranışlarının içsel ve dışsal faktörler tarafından etkilenen dinamik bir alan fonksiyonu olduğunu savunmaktadır. 
Stern (2000) alan teorisi temelinde birey davranışlarını organizmanın kendisi (tutum-attitude) ve çevresinin (bağlam-context) bir fonksiyonu olduğunu ileri sürmüş ve Tutum-Davranış-Bağlam teorisini (Attitude-Behavior-Context Theory) ortaya koymuştur. Jackson'ın (2005) da belirttiği gibi, tutum, bireylerin belirli bir doğrultuda hareket etmesini sağlayan bireysel inanç, değer ve genel yatkınlıkları içerir. Bağlam ise maddi teşvikler, kurumsal ve yasal zorunluluklar, bireyler arası etkileşim vb. gibi potansiyel etkiyi içeren durumlar ile ilgilidir. Tutum (içsel faktörler) ve bağlam (dışsal faktörler) arasındaki yapısal dinamikler tutum davranış bağlam modelinin kritik değişkenleridir. Bu doğrultuda tutum ve davranış arasındaki ilişki; bağlamsal faktörler zayıf olduğunda daha kuvvetlidir, bağlamsal faktörler güçlü olduğunda daha zayıftır.

Örgüt içerisindeki birey davranışlarının farklılı̆ğ örgütsel davranış alanının ana çalışma konusunu oluşturmaktadır. Örgütsel davranış disiplini örgüt içerisindeki bireylerin davranışlarını belirleyen üç öğe üzerinde çalışır: bireyin kendisi, gruplar ve yapı. Bu disiplin, üç öğenin davranışa etkisini açıklayarak örgütleri daha verimli hale getirmek için çalışır (Robbins ve Judge, 2013). Bireylerin neden farklı davranışlar sergilediklerini araştıran çalışmalardan bazıları kişilik ve değerleri (Ajzen, 2005; Rokeach 1973; Schwartz, 1977; Schwartz, 1994), baz1lar1 alg1, atıf ve tutumlar1 (Lancaster 1966, Gutman 1982; Reynolds ve Gutman, 1988; Ajzen ve Fishbein, 1980), bazıları bulunulan ortam özelliklerini (Ajzen ve Fishbein, 1980; Cialdini, Reno, Kallgren, 1990; Ajzen, 1991; Cialdini, Kallgren, Reno, 1991), baz1ları ise kural, kaide ve normları (Elliot ve Wattanasuwan 1998; Schwartz, 1992; Stern vd., 1999; Stern 2000) neden göstermişlerdir.

Geçtiğimiz yıllardaki örgütsel davranış çalışmalarının birçoğu birey davranışı ve performansının öncüllerini araştırmıştır. Bu araştırmalarda davranış; öncelikle kişi ve durum özellikleriyle daha sonra yetenek ve motivasyon ile açıklanmıştır. İlerleyen çalışmalarda ise, bireysel özelliklerin motivasyon ve yeteneği etkileyerek davranışları belirlediği savunulmuş ve sonrasında MARS (Motivation-Ability-Role-Situation) modeli ortaya konmuştur (McShane ve Von Glinow, 2016) (Şekil 1)

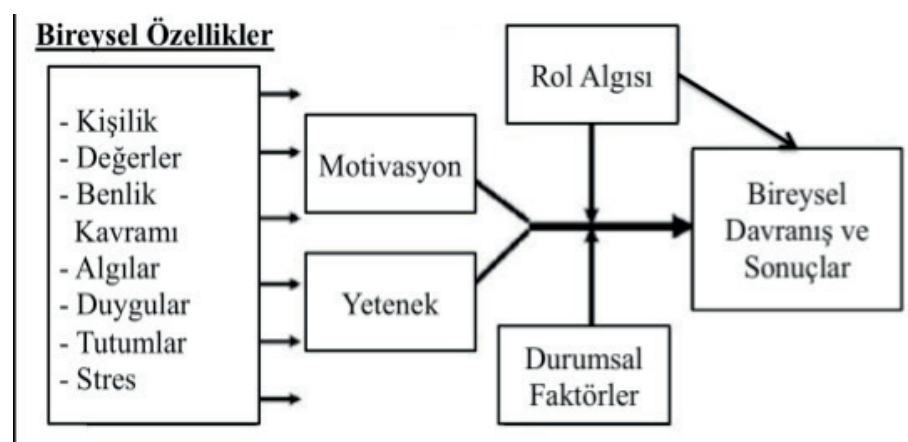

Şekil 1. Mars Modeli (McShane ve Von Glinow, 2016) 
Bireysel özelliklerin bireylerin motivasyonunu etkilediği, motivasyon teorilerinden içsel faktörlere ağırlık veren kapsam teorilerinde de ele alınan bir durumdur. Kapsam teorileri davranış öncesini vurgular ve kişinin içinde bulunduğu ve kişiyi belirli yönlere sevk eden faktörleri anlamaya çalışarak davranışların yönlendirilebileceğini iddia eder (Robbins ve Judge, 2013; Şimşek vd., 2015). Bu iddia, Mars modelindeki bireysel özellik, motivasyon ve davranış nedensellik zincirini destekleyen ve davranışların nedenlerinin birey temelinde açıklanabileceğini gösteren bir yaklaşımdır. Motivasyon teorilerinden dişsal faktörlere ağırlık veren süreç teorilerinde ise; kişinin hangi amaçlar tarafından nasıl motive edildikleri araştırılmaktadır (Koçel, 2010). Bireye ait özellikler, kişiyi davranışa sevk eden faktörlerdendir ancak bu içsel faktörler haricinde birçok dişsal faktör de motivasyon üzerinde rol oynar (Robbins ve Judge, 2013; Şimşek vd., 2015). Bu iddia, Mars modelindeki motivasyon ve davranış arasındaki nedenselliği desteklemekle birlikte, bireyin bir toplum içerisindeki rol algısının davranışa yansımasını da açıklamaktadır. Rol algısı insanların kendilerinden beklenen görevleri yapmak konusunda bulunduğu topluluğa karşı sorumluluğunu ifade eder. Mars modelinde de, bu sorumluluğun bireyin davranışlarını belirli yönlere sevk etmeye neden olduğu ifade edilmektedir (McShane ve Von Glinow, 2016). Modele göre, birey topluluk içindeki rolünü; hem topluluğun beklentilerini karşılama konusunda hem de o topluluktaki normlara uyma konusunda düzenler. Özetle, birey davranışlarında içsel ve dışsal faktörlerin rolünün araştırıldığı çalışmalar (Lewin, 1951, Stern, 2000), örgütsel davranış çerçevesinde birey davranışlarını belirleyen öğelerin ayrımı (bireyin kendisi, gruplar ve yapı) (Robbins ve Judge, 2013), davranış farklılıklarının açıklandığı çalışmaların değerlendirilmesi sonucu ortaya atılan Mars Modeli, içsel ve dişsal motivasyon teorileri ve aynı zamanda klasik ekonomideki rasyonel ve rasyonelliğe aykırı seçim teorileri birey davranışın açıklanmasında bireyin kendisi, bulunduğu (sosyal) bağlam ve yapısal özelliklerin (ahlaki kurallar vb.) ele alınmasının uygun olduğunu göstermektedir. Mars modeli, birey davranışlarının bireysel düzeyde olduğu kadar sosyal ve normatif çerçevede de değerlendirilebileceği gürüşümüzü desteklemektedir.

Organizmanın herhangi bir etkiye karşı gösterdiği tepki şeklinde davranışı tanımlayan Freud, bireyin herhangi bir davranışı daha önce aldığı bir uyarana karşı tepki şeklinde öğrendiğini iddia etmektedir. Freud'un klasik koşullanma olarak adlandırdığı bu öğrenme biçiminden sonra, Skinner davranışların sonucuna odaklanmış ve bireylerin davranış sonucunda elde ettikleri veya kaybettikleri (pekiştireç- ödül/ceza) ile bir değerlendirme yaparak sonraki davranışlarını düzenlediğini savunmuştur. Daha sonra Tolman bireylerin davranışlarının bir uyarana karşı tepki olarak kısıtlandırılamayacağını, bireyin uyarana tepki göstermesi esnasında zihinsel süreçlerini kullanarak davranışını belirlediğini vurgulamaktadır (Şimşek vd., 2015). Birey bazı davranışlarını önceki deneyimleri ve koşullamalar doğrultusunda (klasik koşullanma); bazılarını bu davranış sonucu elde edecekleri/ 
kaybedecekleri doğrultusunda (edimsel koşullanma); bazı davranışlarını ise, belirli zihinsel süreçlerden geçirerek yaptığı analizler doğrultusunda (bilişsel öğrenme) düzenlemektedir (Şimşek vd., 2015). Bireyin belirli davranışları ise sosyal çevresinden öğrendiği ilk defa Bandura'nın (1986) ortaya attı̆ğ1 sosyal bilişsel teori ile ortaya konmuştur. Sosyal öğrenme olarak da adlandırılan bu teori; bireylerin başkalarının tecrübelerinden öğrenerek davranışlarını buna göre düzenleyeceklerini savunmaktadır. Dolayısıyla bireylerin içinde bulundukları topluluklar kişinin davranışlarında etkili olmaktadır. Davranışın sosyal boyutunu açıklayan bir diğer teori ise Blau (1964)'nun Sosyal Mübadele Teorisidir. Bu teori bireyin belirli davranışları, karşıdakilerden aynı/benzer davranışı beklediğinden dolayı sergilediğini savunmaktadır. Dolayısıyla bireylerin etrafindakilere kendisine nasıl davranılmasını istiyorsa o şekilde davranacağını iddia etmektedir. Birey davranışlarının normatif boyutunda ise, bireyin doğru olanı yapma konusundaki idealist davranışları da bulunmaktadır. İdealizimde bireylerin diğer bireylerin refahına yönelik bir eğilimi bulunmaktadır (Forsyth, 1992). Ayrıca idelist bireylerde her durum veya koşulda doğru davranış biçiminin herkesin yararına olacağı inancı bulunmaktadır (Kleiser, Sivadas, Kellaris ve Dahlstrom, 2003). Bu inançla davranışlarını düzenler, diğer bireylere zarar vermekten kaçınır ve tüm paydaşların sonuçlardan tatmin olması gerekliliğini savunurlar.

Birey davranışlarını bilişsel bir süreçte inceleyerek başka bir perspektifte açıklayan bir diğer teori de, rasyonel seçim teorisidir (rational choice theory). Bu teori, bireyin davranışlarını kendi kişisel çıkarları temelinde fayda ve maliyet analizi yaparak düzenlediğini iddia etmektedir (Homans, 1961; Elster, 1986). Davranışı bireysel düzeyde değerlendiren rasyonel seçim teorisinin üç varsayımı bulunmaktadır. Bunlardan ilki seçimin rasyonel olduğu, ikincisi bireyin analiz birimi olarak seçildiği ve üçüncüsü de seçimin bireysel çıkarı izler şekilde yapıldığıdır. Bu teoriden sonra birçok araştırmacı bireyin rasyonelliği konusunu tartışarak rasyonellik karşıtı teoriler (against rational choice) geliştirmiş ve bireyin her zaman rasyonel davranmadığını, belirli zamanlarda rasyonelliğe aykırı davranışlarda bulunduğunu savunmuştur (Simon, 1957; Tversky ve Kahnemann, 1974; Zey, 1992; Etzioni, 1988). Rasyonellik aykırı görüşlerde rasyonel seçim teorisinin üç varsayımı eleştirilmiştir. İlk varsayım olan bireyin her zaman rasyonel hareket etmediği; davranışın alışkanlık (habit), duygular (emotions) gibi bireye ait özellikler ile rasyonel bir seçim sürecinden geçmeyerek de sergilenebileceği fikriyle eleştirilmektedir (Tversky ve Kahnemann, 1974; Etzioni, 1988). İkinci varsayım olan birey analiz düzeyi ise; bireyin sosyal çevresinden bağımsız bir şekilde davranışlarının değerlendirilmesinin eksikliği konusunda bir eleştiri almıştır (Elster, 1986; Gronovetter, 1985; Zey, 1992). Seçimin bireysel çıkarlar izlenerek yapıldığı varsayımı ise; davranışın ahlaki boyutunu değerlendirmemesi konusunda eleştirilmektedir (Hamilton, 1970; Wright, 1994). Görüldüğü gibi, birey davranışını rasyonel seçim teorisi bireysel düzeyde, 
rasyonelliğe aykırı seçim teorileri ise bireysel, sosyal ve normatif düzeyde ele alıp değerlendirmiştir. Rasyonel ve rasyonel seçim karşıtı teorilere göre, çalışmamızın temelini oluşturan birey davranışlarındaki bu ayrım teroik gerekçeleri ile birlikte Tablo 1'de gösterilmiştir.

\section{Tablo 1.}

Rasyonel Seçim Teorisi ve Rasyonnelik Karşıtı Fikirlerin Birey/Sosyal/ Normatif Davranış Eşleşimi (Homans (1961) ve Elster'in (1986) rasyonel seçim; Simon (1957), Tversky ve Kahnemann (1974), Zey (1992) ve Etzioni'nin (1988) rasyonellik karşıtı fikirlerinin uyarlanmasıyla oluşturulmuştur)

\begin{tabular}{|c|c|c|c|c|c|}
\hline & Özellik & Eleştiri Temeli & $\begin{array}{c}\text { Öğrenme Bakış } \\
\text { Açısı }\end{array}$ & Açıklama & $\begin{array}{c}\text { Davranış } \\
\text { Boyutu }\end{array}$ \\
\hline \multicolumn{6}{|c|}{ Rasyonel Seçim Teorisi } \\
\hline 1. Varsayım & $\begin{array}{l}\text { Seçimin } \\
\text { Rasyonel } \\
\text { Olması }\end{array}$ & $\begin{array}{l}\text { Bilişsel olarak } \\
\text { eleştiri (Cognitive } \\
\text { Grounds) }\end{array}$ & $\begin{array}{l}\text { Tolman Bilişsel } \\
\text { Öğrenme } \\
\text { Yaklaşımı }\end{array}$ & $\begin{array}{l}\text { Kişi her uyarıcıya } \\
\text { aynı tepkiyi } \\
\text { göstermez. Zihinsel } \\
\text { süreçlerden } \\
\text { geçirerek belirli } \\
\text { davranışlar sergiler. } \\
\text { Pekiştireç (Ödül/ } \\
\text { Ceza) } \rightarrow \text { Davranış }\end{array}$ & BİREYSEL \\
\hline 2. Varsayım & $\begin{array}{l}\text { Birey } \\
\text { Analiz } \\
\text { Birimi }\end{array}$ & $\begin{array}{l}\text { Sosyal bağlamda } \\
\text { eleştiri (Social } \\
\text { Grounds) }\end{array}$ & & & BİREYSEL \\
\hline 3. Varsayım & $\begin{array}{l}\text { Seçimin } \\
\text { bireysel } \\
\text { çıkarlar } \\
\text { izlenerek } \\
\text { yapılması }\end{array}$ & $\begin{array}{l}\text { Ahlaki boyutta } \\
\text { eleştiri (Moral/ } \\
\text { Epistemological } \\
\text { Grounds } \rightarrow \\
\text { Normative } \\
\text { Grounds) }\end{array}$ & & & BİREYSEL \\
\hline
\end{tabular}

\begin{tabular}{|c|c|c|c|c|c|}
\hline \multicolumn{6}{|c|}{ Rasyonel Seçim Karşıtı Teoriler } \\
\hline $\begin{array}{l}\text { 1. Varsayıma } \\
\text { Eleştiri }\end{array}$ & $\begin{array}{l}\text { Seçimin } \\
\text { Rasyonel } \\
\text { Olması }\end{array}$ & $\begin{array}{l}\text { Birey sinırlı } \\
\text { rasyoneldir, her } \\
\text { zaman rasyonel bir } \\
\text { şekilde davranmaz }\end{array}$ & $\begin{array}{l}\text { Alışkanlık, } \\
\text { Duygusal, Sinırlı } \\
\text { Rasyonellik } \\
\text { (Habitual, } \\
\text { Emotional, } \\
\text { Bounded } \\
\text { Rationality) }\end{array}$ & $\begin{array}{l}\text { Bilinçaltı, } \\
\text { İçgüdüler, Uyarılar } \\
\rightarrow \text { Davranış }\end{array}$ & BİREYSEL \\
\hline $\begin{array}{l}\text { 2. Varsayıma } \\
\text { Eleştiri }\end{array}$ & $\begin{array}{l}\text { Birey } \\
\text { Analiz } \\
\text { Birimi }\end{array}$ & $\begin{array}{l}\text { Sosyal yapılar } \\
\text { birey davranışları } \\
\text { üzerinde etkilidir. }\end{array}$ & $\begin{array}{l}\text { Sosyal Bilişsel } \\
\text { Teori (Social } \\
\text { Cognitive Theory }\end{array}$ & $\begin{array}{l}\text { Bireyler } \\
\text { sosyal yapının } \\
\text { etkisi altında } \\
\text { davranışlarını } \\
\text { düzenler. }\end{array}$ & SOSYAL \\
\hline $\begin{array}{l}\text { 3. Varsayıma } \\
\text { Eleştiri }\end{array}$ & $\begin{array}{l}\text { Seçimin } \\
\text { bireysel } \\
\text { çıkarlar } \\
\text { izlenerek } \\
\text { yapılması }\end{array}$ & $\begin{array}{l}\text { Toplumun } \\
\text { çıkarları ve } \\
\text { kurallar birey } \\
\text { davranışını } \\
\text { belirleyebilir. }\end{array}$ & Ahlaki (Moral) & & NORMATİF \\
\hline
\end{tabular}

Çalışmamızın bu aşamasında, yukarıda açıklanan alan kuramı (Lewin, 1951), tutum davranış bağlam teorisi, Mars modeli, içsel/ dışsal motivasyon teorisi, öğrenme teorileri (klasik, edimsel (Ödül/ceza), bilişsel, sosyal - sosyal bilişsel teori), sosyal 
mübadele teorisi, idealism, rasyonel seçim teorisi ve rasyonellik karşıtı görüşler temel alınarak başka bir ifadeyle bu 12 davranış teorisinden yararlanarak, birey davranışları bireysel, sosyal ve normatif boyutlarda gruplandrılması tarafımızdan uygun görülmüştür.

\section{Davranışların Bireysel, Sosyal ve Normatif Boyutu Açısından Teori, Yaklaşım ve Modellerin İncelenmesi}

Yukarıdaki teorik alt yapıda yapılan açıklamalardan hareketle, bu çalışma kapsamında literatürde ayrı şekillerde ele alınıp değerlendirilmiş davranış teorileri, bireyin davranışının bireysel, sosyal ve normatif boyutları olarak üç ayrı majör katogoride kavramsallaştırılmıştır. Jackson (2005) sürdürülebilir tüketim hakkında yapmış olduğu kapsamlı çalışmada, literatürdeki birçok davranış teorisini müşterilerin tercih ve seçimlerini açıklamak için sınıflandırmıştır. Birey davranışlarının boyutlarını araştırdığımız çalışmamızın bu aşamasında, hem Jackson'ın (2005) çalışmasında değerlendirdiği teoriler ${ }^{2}$ hem de literatürde kabul görmüş davranış teorileri, yaklaşım ve modelleri dikkate alınarak ayrıntılı analizleri yapılmış ve bu teori, yaklaşım ve modellerde incelenen davranışlar bireysel, sosyal ve normatif düzeyde gruplandırılmış (Tablo 2) ve çalışmanın ilerleyen kısımlarında bu gruplama ayrıntılı olarak verilmiştir. Bu amaçla incelenen teori, yaklaşım ve modeller: Ekolojik Değer Teorisi (Jackson, 2005), Basit Beklenti Değer Tutum Teorisi (Fishbein, 1973), Nedenli Eylem Teorisi (Ajzen ve Fishbein 1980), Planlanmış Davranış Teorisi (Ajzen 1991), Sembolik Benlik Tamamlama Teorisi (Wicklund ve Gollwitzer, 1982; Elliott ve Wattanasuwan, 1998), Benlik Algısı Teorisi (Bem, 1972), Bilişsel Uyumsuzluk Teorisi (Festinger, 1957), Normatif Davranışa Odaklanma Teorisi(Cialdini vd. 1990; 1991). Sosyal sembolik benlik teorisi (Mead, 1934), Benlik Farklılığ1 Teorisi (Higgins, 1987), Sosyal kimlik teorisi (Tajfel ve Turner, 1979), Kültürel Teori (Thompson, Ellis ve Wildavsky, 1990; Douglas, 1997), Değer İnanç Norm Teorisi (Stern vd., 1999; Stern 2000), Norm Aksiyon Modeli (Schwartz, 1977; 1992), Çevreci Kimlik Teorisi (Van der Werff, Steg ve Keizer, 2013), Bireylerarası Davranış Teorisi (Triandis, 1977), Motivasyon Firsat Yetenek Modeli (Ölander ve Thogersen 1995), Yapılandırma Teorisi (Giddens, 1979;1984), Bilişsel Çaba - Kontrol, Otomatikleşme ve Sezgisel Yaklaşım (Jager, 2003), Çerçeveleme, Önceliklendirme ve Yanlılık Yaklaşımı (Tversky ve Kahneman, 1974), Prososyal Davranış (Berkowitz, 1972; Krebs, 1982; Eisenberg, Cameron, Tryon ve Dodez, 1981), Örgütsel Yardım Etme Davranışı (Podsakoff, MacKenzie, Paine ve Bachrach, 2000), Örgütsel Vatandaşlık

2 Rasyonel Seçim Teorisi, Rasyonel Seçim Karşııtı Teoriler, Basit Beklenti Değer Tutum Teorisi, Nedenli Eylem Teorisi, Planlanmış Davranış Teorisi, Sembolik Benlik Tamamlama Teorisi, Benlik Algısı Teorisi, Bilişsel Uyumsuzluk Teorisi, Normatif Davranışa Odaklanma Teorisi, Sosyal sembolik benlik teorisi, Benlik Farklılığı Teorisi, Sosyal kimlik teorisi, Kültürel Teori, Değer İnanç Norm Teorisi, Norm Aksiyon Modeli, Çevreci Kimlik Teorisi, Bireylerarası Davranış Teorisi, Motivasyon Fırsat Yetenek Modeli, Yapılandırma Teorisi, Bilişsel Çaba - Kontrol, Otomatikleşme ve Sezgisel Yaklaşım, Çerçeveleme, Önceliklendirme ve Yanlılık Yaklaşımı. 
Davranış1 (Organ, 1990), Fikrini Açıkça Söyleme Davranış1 (Hirschman, 1970), Çevreci Örgütsel Vatandaşlık Davranışı (Boiral, 2009); Etik Davranış Teorisidir (Taylor, 1975; Ferrell ve Skinner, 1988).

\section{Davranışın Bireysel Boyutu}

Dış çevreden gelen uyarılar, içgüdüler ve doğuştan gelen özellikler (Pavlov, 1941; Watson 1958) yanında, sonraki deneyimlerinden öğrenilenler (Skinner, 1953) ve bu öğrenilenlerden alışkanlık haline getirilenler (Johnson ve Hasher, 1987) bireylerin davranışlarını düzenlemede etkilidir. Rasyonel seçim teorisine göre de (rational choice theory), birey davranışlarını kendi kişisel çıkarları temelinde fayda ve maliyet analizi yaparak düzenlemektedir. Birey maddi (ödül, ceza, terfi vb.) veya manevi (kendi mutlu, iyi, değerli hissettiren) çıkarının maksimum olduğu noktaya ulaşmak için çaba harcamaktadır (Homans, 1961; Elster, 1986). Bireylerin kendi çıkarları kapsamında her bir davranışın sonucunu irdeleyerek davranışlarını düzenlediği, (Sen, 1984) diğer taraftan irdeleyemeyecek kadar karmaşık durumlarda alışkanlıkları, rutinler ve duygularıyla hareket ettiği (Bargh, 1994) davranışın bireysel çerçevede açıklanmasına olanak sağlamaktadır.

Yukarıda yapılan açıklamalar doğrultusunda davranışın bireysel boyutu değerlendirildiğinde, bireysel boyutda; bireyin kendisine yönelik olarak yaptı̆̆ faydamaliyet analizi söz konusudur. Birey bu analiz sonucunda kendi çıkarı doğrultusunda davranışlarını düzenleyecektir. Bu çıkarın maddi olduğu kadar manevi bir boyutu da bulunmaktadır. Yani birey duygusal olarak kendini mutlu ve tatmin eden veya kendini iyi hissettiği, değerli bulduğu sonuçlar doğrultusunda da hareket edecektir. Hatta birey bazen kendini görmek istediği gibi, kişisel norm ve değer yargılarının yönlendirmesiyle davranışlarını sergileyecektir. Ancak bazı durum ve koşullar bireyin analiz yapmasını gerektirmeyecek kadar sıradandır. Bu durumda birey rutin ve alışkın olduğu davranışları sergilemeye meyilli olacaktır. Diğer taraftan, birey her durum ve koşulda bir fayda maliyet analizi yapamayabilir. Sınırlı rasyonel olarak kabul edilen birey kendi düşünce alanını aşan durumlarda sezgileri, önceden öğrendikleri, hatta duyguları ile davranışlarını düzenleyebilir. Bu kısımda ele alınan teori, yaklaşım ve modellerde davranışın bireysel boyutu yukarıda bahsi geçen kapsamda incelenip değerlendirilmiştir.

Rasyonel seçim teorisi (rational choice theory) temelde Adam Smith, John Stuart Mill ve Jeremy Bentham tarafindan ortaya atılan çıkarcı ekonomik insan (selfinterested economic person) modeline dayanır (Sen, 1984; Russell 2000) ve bu teorinin yukarıda belirtildiği gibi üç varsayımı bulunmaktadır. Bunlardan ilki seçimin rasyonel olduğu, ikincisi sosyal bağlamdaki bireyin analiz birimi olarak seçildiği ve sonuncusu da seçimin bireysel çıkarı izler şekilde yapıldığıdır. Davranışların nedenlerini birey temelinde açıklayan bu teori bireyin beklediği fayda ve maliyet 
değerlendirmesi yaparak davranışlarını düzenlediğini iddia etmektedir (Homans, 1961; Elster, 1986). Bireyin kendisi açısından yaptığı bu değerlendirme, davranışın ortaya çıkmadan zihinsel bir süreçten geçtiğinin bir göstergesidir. Bilişsel öğrenmenin (Tolman) aktif rol aldığı bu süreçte, davranışın sonucunda elde edilecekler cinsiden bir irdeleme yapması nedeniyle pekiştirmenin (Skinner) de etkili olduğu söylenebilir ${ }^{3}$. Klasik ekonomideki çıkarcı ekonomik insan (self-interested economic person) bakış açısıyla geliştirilmiş rasyonel seçim teorisinde, bireysel çıkarlar insan davranışlarını açıklamada en uygun çerçeve olarak görülür. Jackson'ın (2005) Şekil 2'deki gibi görselleştırdiği rasyonel seçim teorisi, bireylerin kendi çıkarlarını koruyacak şekilde davranışlarını düzenlediğini iddia etmektedir.

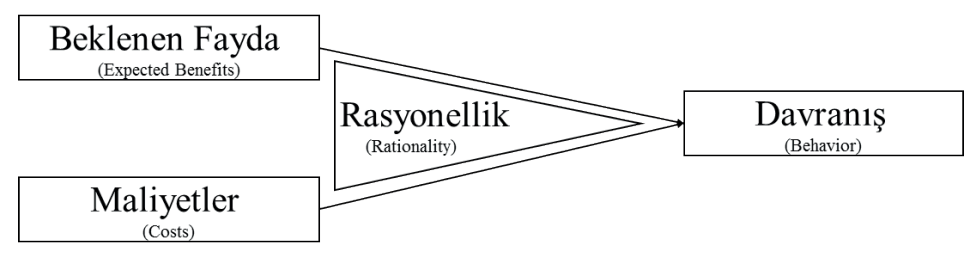

Şekil 2: Rasyonel Seçim Teorisi (Jackson, 2005)

Bazı sosyal psikolojik modeller birey davranışını rasyonel seçim teorisinden daha ayrıntılı kavramsallaştırmaktadır. Rasyonel seçim teorisinde bireyin herhangi bir davranışının fayda ve maliyet açısından değerlendirmesi sonucu ortaya çıktığı iddia edilmiştir. Ancak basit - beklenti - değer tutum teorisi (Simple ExpectancyValue Attitude Theory) bireyin davranışlarını açıklamada beklenti ${ }^{4}$ ve değerler gibi psikolojik unsurları da modele dahil ettiği için rasyonel seçim teorisinin ötesinde bir teoridir (Fishbein, 1973). Dolayısıyla rasyonel seçim varsayımlarından başka birey davranışlarının psikolojik öncülleri bu teori kapsamında incelenmiştir. Basit beklenti - değer - tutum teorisinde tercihlerin beklenen çıktılar temelinde oluştuğundan bahsedilmektedir. Jackson'ın (2005) ifade ettiği gibi, beklenen çıktılar, bu çıktıya verilen değere göre analiz edilerek tutum/davranışa yansıyacaktır.

3 Organizmanın herhangi bir etkiye karşı gösterdiği tepki şeklinde davranışı tanımlayan Freud, bireyin herhangi bir davranışı daha önce aldığ 1 bir uyarana karşı tepki şeklinde öğrendiğini iddia etmektedir. Freud'un klasik koşullanma olarak adlandırdığı bu öğrenme biçiminden sonra, Skinner davranışların sonucuna odaklanmış ve bireylerin davranış sonucunda elde ettikleri veya kaybettikleri (pekiştireç- ödül/ceza) ile bir değerlendirme yaparak sonraki davranışlarını düzenlediğini savunmuştur. Daha sonra Tolman bireylerin davranışlarının bir uyarana karşı tepki olarak kısıtlandırılamayacağını,bireyin uyarana tepki göstermesi esnasında zihinsel süreçlerini kullanarak davranışını belirlediğini vurgulamaktadır.

4 Beklenti kavramı bilişsel öğrenme teorisini ortaya atan Tolman tarafından amaçlı davranışçılık kapsamında açıklanmaktadır. Tolman'dan önce davranış, bireylere verilen bir uyarı karşısında bireyin gösterdiği tepki olarak tanımlanmaktadır (Davranışçı Yaklaşım - Pavlov, Skinner). Daha sonra Tolman bireylere dış çevreden verilen bir uyarı karşısında bireyin kendisinde oluşan bir beklenti olarak davranışı tanımlamıştır. Davranışçı yaklaşıma göre kapı zili çaldığında bireyin kapıyı açması uyarana karşı tepki şeklinde davranışı açıklamaktadır. Tolman ise kapı zilinin çalması bireyde misafir geldiğine yönelik bir beklenti oluşturduğundan dolayı uyaran başka bir uyaranı etkileyerek davranışı şekillendireceğini iddia eder. Bu temelde davranışçı yaklaşımdan sonra amaçlı davranışçılık yaklaşımını başlatmıştır. Amaçlı davranışçılıkta organizmanın çevrede kendini amaçlarına ulaştıracak işaretleri öğrendiğine odaklanılır. 
Literatürde bireylerin davranışlarını açıklamak için ortaya konan teorilerden bir diğeri ise Nedenli Eylem Teorisi (Theory of Reasoned Action) (Ajzen ve Fishbein, 1980) ve onun biraz daha gelişmişi olan Planlanmış Davranış Teorisidir (Theory of Planned Behavior) (Ajzen, 1991). Nedenli eylem teorisinde bireyin belirli inançları temelinde geliştirdiği tutumlarının niyetlerine ve dolayısıyla davranışa yansıyacağı iddia edilmektedir. Bu nedenle nedenli eylem teorisi (Şekil 3) ve onun gelişmişi olan planlanmış davranış teorisinin (Şekil 12), birey davranışlarını bireysel düzeyde açıklayan bir tarafı bulunmaktadır. Tudor ve diğerleri (2007) planlanmış davranış teorisi temelinde, ev ve çalışma ortamında sergilenen çevreci davranışı ayrı ayrı değerlendirmiş, evinde geri dönüşümü esas alan uygulamalarda bulunan bireylerin, iş yerinde de bu davranışı sürdürme konusunda pozitif tutum içerinde oldukları sonucuna ulaşmıştır.

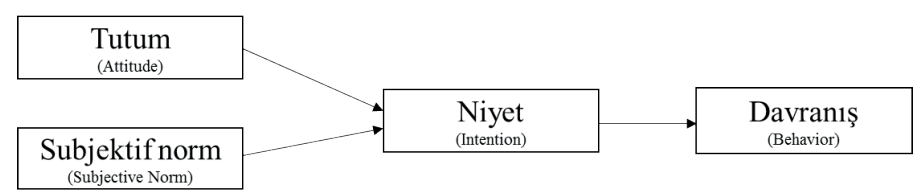

Şekil 3: Nedenli Eylem Teorisi (Ajzen ve Fishbein, 1980)

Bireylerin davranışlarını bireysel çerçevede açıklayan teorilerden bir diğeri Bem'in (1972) ortaya attığ 1 Benlik Alg1sı teorisidir (Self-Perception Theory). Bir yönüyle bu teoriye göre bireylerin kendi davranışlarını izleyerek edindikleri kendileri (self-concept) hakkındaki algıları, bireyleri belirli bir şekilde davranmaya motive etmektedir. Bu kapsamda benlik algısı teorisi, kendisinin nasıl olduğunu düşünüyorsa, kişinin belirli bir konudaki niyet ve davranışları da o şekilde gerçekleşeceğini iddia etmektedir.

Benlik alg1sı teorisini destekler nitelikte, Festinger (1957) tarafindan ortaya atılan bilişsel uyumsuzluk teorisi (Cognitive Dissonance Theory) de, kişilerin kendileri konusunda çelişen tutum ve davranışları olduğunda, bu çelişkiyi ortadan kaldırmak için içsel veya dışsal gerekçeye ihtiyaç duyduklarını iddia eder. Bilişsel uyumsuzluk teorisi ile ilgili en çok bilinen iki deney (duvarda vida sıkma deneyi ve polisler hakkındaki tutum deneyi ${ }^{5}$ ) tutum ve davranışlar arasındaki uyumsuzluk karşısında

5 1. Vida deneyi:Bir duvarda yüzlerce vida vardır ve denek onları teker teker sıkmak durumundadır. Bu eylem 1 saat sürmektedir. Denek deneyin bittiğini sanar ama deney daha yeni başlamıştır. Denek deney ortamından ayrılırken, psikologlar asistan öğrencinin şu anda orda olmadığını söylerler ve mümkünse bir sonraki deneği içeri çağırmasını ve deneğin performansını yüksek tutması için "az önce ben de deneyden çıktım çok eğlenceliydi” demesini isterler. Bazı deneklere bunu yapması için 10\$ verirler bazılarına ise hiç para vermezler. Denek gider, bir sonraki deneğe "çok eğlenceli bir deneydi" diye bir yalan söyler ve onu çağırır. Kapıdan çıkarken her deneğe deneyden ne kadar zevk aldığına dair gerçek bir anket yaparlar. Sonuçlar oldukça şaşırtıcıdır. 10\$ alanlar deneyin çok sıkıcı olduğunu, hiçbir şey almayanlar deneyin fena olmadığını hatta zevkli olduğunu söylerler.

2. Polis deneyi: Berkeley'de öğrenciler polise karşı gösteri yaparken, polis bu öğrencileri şiddet uygulayarak dağıtmıştır. Gösteri yapan bu öğrencilerden rastgele 50 öğrenci seçilir ve bunlardan polis neden haklıydı sorusuna cevap verecekleri bir mektup yazmalarını istenir. Öğrencilerin yarısına bu mektubu yazmaları için $30 \$$ 
bireylerin bu uyumsuzluğu ortadan kaldırma çabalarını göstermektedir. Deneyde deneklerden sıkıcı bir iş yaptıktan sonra bu işin sıkıcı olmadığını belirtmeleri istenmiş ya da polise karşı olumsuz tutumları varken polisin lehine bir makale yazmaları istenmiştir. Deneklerin tutum ve davranışları arasında oluşturulan bu uyumsuzluk bireyler tarafından dişsal veya içsel faktörlerle açıklanmaya çalışılmıştır. İstenen davranışı sergilemeleri için para (dışsal gerekçe) alan denekler, tutumlarından farklı bu davranışı kendi çıkarları için para karşılığında yaptıklarını düşünerek uyumsuzluğu ortadan kaldırmışlardır. Bu yönüyle deneklerin bu davranışı bireysel boyutta değerlendirilmiştir.

Higgins'in (1987) benlik farklılığı teorisi (self-discrepancy theory), birey davranışını bireysel boyuttaki içsel farklılıklar ile de açıklayan bir diğer davranışsal teoridir. Bu teori bir yönüyle, bir bireyin kendisi ile ilgili algısını (self-concept) gerçekte nasıl olduğu, nasıl olması gerektiği,1 ve idealde nasıl olması gerektiği ile kıyaslamakta ve buna göre bireyin davranışlarını düzenlediğini iddia etmektedir. Higgins'in (1987) geliştiridiği benlik farklılığı teorisi Jackson (2005) tarafindan Şekil 4'teki gibi gösterilmiştir.

\begin{tabular}{|c|c|c|}
\hline $\begin{array}{c}\text { Gerçek Kendi } \\
\text { (Actual-Own) }\end{array}$ & $\begin{array}{c}\text { Gelecekteki Kendi } \\
\text { (Ought-Own) }\end{array}$ & Ideal Kendi \\
\hline (Ideal-Own)
\end{tabular}

Şekil 4: Benlik Farklılığı Teorisi (Jackson, 2005)

Birey davranışlarını sosyal kapsamda açılayan diğer bir teori Douglas'ın (1997) ortaya attığı kültürel teoridir (Cultural Theory). Sosyal farklılıklar, kültürel farklılıklardan kaynaklanan davranış değişikliğini açıklamada önemlidir. Rasyonel bir bireyin temel seçimi ne tür bir toplum içerisinde yaşayacağı tercihidir. Oysa bireyler yaşayacağı toplumu seçme şansına çoğu zaman ilerleyen yaşlarda erişebilirler. Douglas (1997) sosyal organizasyonlarda 4 temel kültür yapısı olduğunu ve bu kültürel yapılarının birey davranışlarını etkilediğini iddia etmiştir. Mevcut toplumdaki bireyler arasındaki ilişkilerin bağımsızlığı (free) ve kısıtlama (constraint) düzeyine göre (düşükyüksek) ve toplumdaki bireylerin topluma zıt olma koşullarının önemine göre (düşük-

verilmiş diğer yarısına herhangi bir ücret verilmemiştir. Mektup yazdıktan sonra 50 öğrenciye yaptıkları eylem hakkındaki görüşleri sorulur. Mektup yazmak için 30\$ alanlar öğrenci polisin haklı olmadığını belirtirken, ücret almayanların polisin haklı olduğunu söyledikleri tespit edilmiştir. Herhangi bir para almayan denekler, tutum ve davranışları arasındaki uyumsuzluğu dışsal bir nedenle açıklayamadıkları için, bilişsel uyumsuzluğu ortadan kaldırmak amacıyla, davranışlarını değiştiremediklerinden tutumlarını değiştirmişlerdir. Yani gerçekten sevmedikleri bir işin aslında çok da kötü olmadığı ya da polisin aslında haklı olabileceği konusunda tutumlar (içsel gerekçe) geliştirmişlerdir. 
yüksek) bir grid oluşturulmuş ve 4 ayrı kültürel düzey tanımlanmıştır; kaderci (fatalist), bireyci/ egoist (individualist), hiyerarşist (hierarchist), eşitlikçi (egalitarian). (Şekil 5).

Yüksek Grid

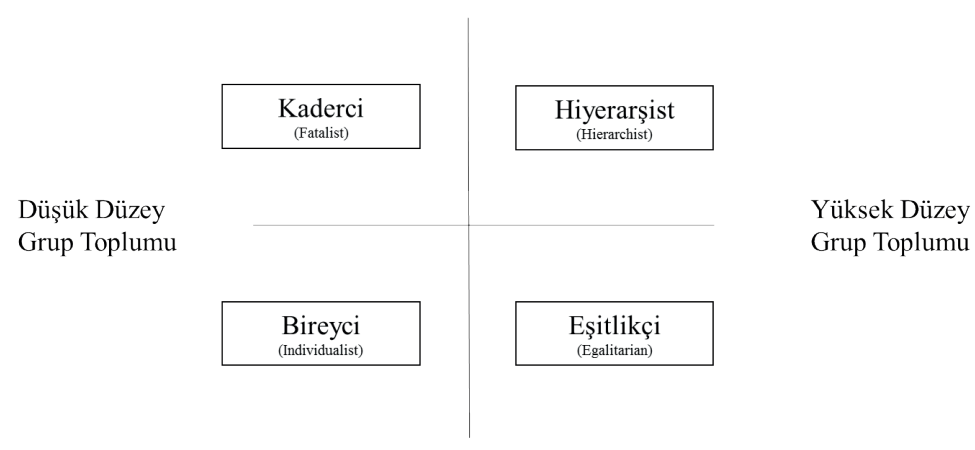

Düșük Grid

Şekil 5: Kültürel Teori (Douglas, 1997)

Douglas'ın (1997) kültürel teorisi (Cultural Theory), bireyin içinde bulunduğu kültürün, birey davranışlarını belirleyeceği görüşünü savunmakta ve ortaya koyduğu bu kaderci (fatalist), bireyci/ egoist (individualist), hiyerarşist (hierarchist), eşitlikçi (egalitarian) olarak tanımlanan kültürlerden, kaderci ve bireyci olanlar bireylere kendi davranışlarını kendi düzenleyebilme imkanı sağlamaktadır ${ }^{6}$. Burada kaderci (fatalist) kültür, bireyler arası izolasyonun yüksek olduğu, seçilerek veya zorunlu olarak bir sistem içerinde tecrit edilmiş (Çalışkan, 2016) bir kültür yapısıdır. Bu kültürde kurallar başkası tarafindan belirlenmekte, bireyin bu kurallara müdahale etme şansı bulunmamaktadır. Örgüt düzeyindeki kaderci kültürde benzer şekilde, kural koyucular tarafindan yönetilen ve manipüle edilen, bir kültürde bireyin sistemin ilerleyişine (kaderine) razı olduğu ve bu sistem içerisinde kendi çıkarını düşünerek hayatta kalmaya, varlığını sürdürmeye çalıştı̆̆ı bir kültürdür (Thompson, 2018). Bireyci (individualist) kültür ise, büyük çaplı girişimlerin yapıldığı, açık ă̆ sistemine sahip olan, bireylerin birbirleriyle iletişim halinde olduğu ancak rekabet, inovasyon, bireysel seçim kişisel özgürlüğün bulunduğu kültürlerdir. Bireyci kültürlerde bireyler materyalistik bir bakış açısına sahiptir ve kendi kişisel stratejileri ile zenginlik ve refaha ulaşmayı amaçlarlar (Thompson, 2018). Dolayısıyla bireyci

6 Yüksek Grid (High Grid): Bu düzeyde bireylerin birbiri ile ilişkilerini ve değişimlerini sınırlandıracak bireyler arası izolasyon vardır. Bireyler arası ilişkiler yasaklanmıştır ve bireyler arası asimetrik ilişkiler bulunur. Düșük Grid (Low Grid): Bireyler arasında izolasyonun olmadığı, bireyler arası ilişkilerin özgürce ve sınırsızca kurulduğu durumlardaki simetrik ilişkilerin öne çıktığı düzeydir.

Yüksek Düzey Grup Toplumu (High Group): Grup değerlerinde uzlaşmanın yaşandığı, birey hareketleri grup normları tarafından kısıtlandığı ve toplumun grup ilişkileri etrafında organize edildiği grup düzeyidir.

Düșük Düzey Grup Toplumu (Low Group): Grup üzerinde bireylerin baskınlığının olduğu, rekabet engeli olmayan bir hakimiyetle birey çıkarlarının ön plana alındı̆̆ı, grup değer ve normlarının ikinci planda tutulduğu grup düzeyidir. 
kültürlerin bireylere kendi istekleri veya çıkarları doğrultusunda kendi davranışlarını düzenleyebilme imkanı tanımasından ötürü kültürel teorinin bireyci/egoist boyutu, kaderci boyut ile birlikte bireysel boyutta değerlendirilmesine olanak tanımaktadır.

Şekil 16'da gösterilen, Stern vd.'nin (1999) değer-inanç norm teorisinde, kişinin değer yargıları temelinde yeni çevre paradigmasının bireyler tarafindan kabulünün değiştiği belirtilmiştir (Dunlap, Van Liere, Mertig, ve Jones, 2000). Burada yeni çevre paradigması; insan ve doğa arasındaki ilişkiyi ve insanın varoluşunun doğanın bir parçası olması fikrini temel alan bir inanışıtır. Buna göre, yüksek derecede egoist bireyler, muhtemelen diğer yaşayan varlıkları kendi benlik kavramları içerisinde tanımlamayacakları için, yeni çevre paradigmasını destekleme ihtimalleri düşük olacaktır. Yeni çevre paradigmasını kabul eden bireylerin ise, çevreci davranış gösterme ihtimallerinin daha yüksek olduğu bu teorinin kapsamında savunulan bir görüştür. Dolayısıyla bireyin çıkarını (egoism) göz önünde bulunduran bir değer yargısının yeni çevre paradigmasının kabulünü güçleştireceği ve bunun da çevreci davranışa yansımasının kayda değer olmayacağı söylenebilir. Diğer taraftan değer inanç norm teorisi; bireylerin belirli değerleri çerçevesinde, özellikle farkında olduğu ve kendini sorumlu hissettiği konularda kişisel (personal) normlar geliştirdiğinden, bu normların ise bireyin davranışlarına yansıdığından bahsetmektedir. Burada bahsi geçen bireysel normlar bireyin çıkarları ile ilgili olmayıp, kişinin kendi için geliştirdiği içsel kurallardır (Doran ve Larsen, 2016; Onwezen, Antonides ve Bartels, 2013). Birey bu kurallar çerçevesinde hareket ettiğinde duygusal bir tatmin, aksi yönde hareket ettiğinde ise rahatsızlık hissettiği için, değer inanç norm teorisinin egoist değerler yanında kişisel normlara uyum nedeniyle bireysel boyutta incelenebileceği söylenebilir.

Değer-inanç norm teorisine benzer şekilde, Jackson'ın (2005) geliştirdiği ekolojik değerler teorisinde de bireylerin sahip oldukları değer yargıları doğrultusunda hareket ettiğinden bahsedilmektedir. Şekil $15^{\prime}$ te gösterilen ve normatif boyutta açıklanan ekolojik değer teorisinin; prososyal değerlerin tüm insanların refahını gözeten değerler olarak davranışı etkilediği görülmektedir. Ancak prososyal davranışın analizde de belirtildiği gibi, bireyin başkalarını düşünerek davranışlarını düzenlemesinin altında duygusal bir tatmin hissetmek veya bu şekilde davranmadığında rahatsızlık hissetmek gibi nedenler yatabilir. Bu çerçeveden bakıldığında; ekolojik değerler teorisinde bahsi geçen prososyal değerlere sahip olan bireylerin davranışlarının, bireysel düzeyde incelenecek bir yönünün olduğu söylenebilir.

Kişisel normların bireyin özgecil davranışlarında etkili olduğunu savunan Schwartz (1977; 1992)'in çalışmaları temelinde, Steg ve De Groot (2010) Şekil 6'da görülen norm aksiyon modelini geliştirmiştir. Bu modelde; birey kendi davranışlarının getirdiği sonuçların ne kadar çok farkındaysa, kendini o kadar sorumlu hissedeceği ve bu doğrultuda kişisel normlar geliştireceği, sonuçta da bu normlar çerçevesinde 
hareket edeceğinden bahsetmektedir (Steg ve De Groot, 2010). Bireylerin kendince doğru olan çerçevesinde kendi geliştirdikleri normlara uyduğunda bir duygusal tatmin uymadığında ise bir rahatsızlık (Onwezen vd., 2013) duyacaktır. Bireyler bazen bu rahatsızlıktan kaçınmak için belirli davranışlar sergiledikleri göz önünde bulundurulduğunda, norm aksiyon modelinin bireysel bir yönünün olduğu söylenebilir.

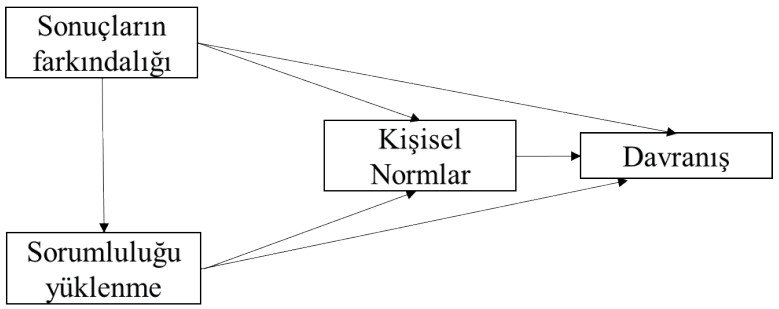

Şekil 6: Norm Aksiyon Modeli (Steg ve De Groot, 2010)

Sosyal kimlik teorisi; bireylerin kendi kimliklerini mensup oldukları grup veya içinde bulunduğu topluluklardan etkilenerek oluşturduğunu iddia etmektedir. $\mathrm{Bu}$ çerçevede kimlik bireyin kendini tanımlama biçimi veya başkalarına tanıtma biçimi olarak tanımlanabilir (Tajfel ve Turner, 1979). Sosyal ve örgütsel bağlamda yapılan çalışmalar, bireylerin içinde bulundukları topluluğa göre benimsenen/ gösterilen kimliğin değişebileceğini göstermektedir (Roccas ve Brewer; 2002; Mendeş Pekdemir ve Turan, 2014; Turan, 2015). Bunun nedeni ise, bireyin bazı duygu ve değerler bakımından, mevcut grubun üyesi olmaktan dolayı kendini memnun hissetmesi (Tajfel ve Turner, 1979) ve bu memnuniyeti bildirmesinin uygun olduğu ortamlarda bunu kimliği ile özdeşleştirmesidir. Bu kimlik geliştirme süreci Jackson (2005) tarafından Şekil 7'deki gibi gösterilmiştir. Dolayısıyla sosyal kimlik teorisinde birey kendi kimliğini oluştururken ve o kimlik ile kendini başkalarına tanıtırken, duygusal olarak onu tatmin edecek şekilde bir kimlik geliştirecektir. Bu kapsamda sosyal kimlik teorisinin birey davranışlarını açılamada sosyal yönünün yanında bir de bireysel bir tarafı bulunduğu söylenebilir.

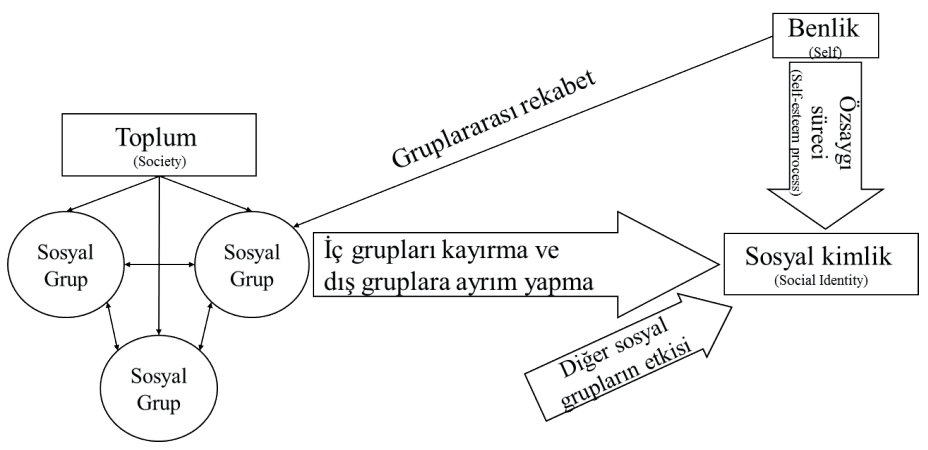

Şekil 7: Sosyal Kimlik Teorisi (Jackson, 2005) 
Çevreci kimlik teorisine göre çevreci kimlik bireylerin kendilerini çevreyi koruyan ve zarar vermeyen ve çevre konusunda hassas biri olarak görmeleri ve tanımlamaları ile oluşmaktadır (Van der Werff vd., 2013). Dolayısıyla bireyde bu kimliğin gelişimi ve bireyin bu kimlikle kendini tanımlaması birey davranışlarının da bu yönde gelişmesini sağlayacaktır. Kişi kendini çevreci olarak gördüğu için bu kimliğe paralel davrandığında duygusal bir tatmin, kimliğe aksi davrandığında rahatsızlık hissedecektir. Dolayısıyla çevreci kimliğin bireysel bir yönü bulunmaktadır.

Sembolik benlik tamamlama kavramı ilk kez Gollwitzer, Wicklund, Hilton (1982) tarafindan, Lewin (1951)'in teorisi genişletilerek ortaya atılmış ve davranışsal bir kapsamda açıklanmıştır. Daha sonra Elliott ve Wattanasuwan (1998) bu teoriyi Şekil

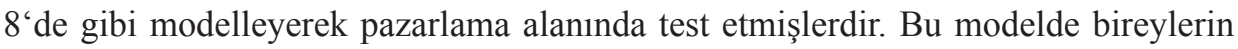
kendi kimliklerini geliştirirken maddi (material) ve sembolik (symbolic) kaynakları birleştirdiğinden bahsetmektedir ${ }^{7}$. Birey kendi yaşamında önemli olarak gördüğü bazı maddi kaynaklara ulaştığında kendini başarılı olarak görmektedir (iyi bir ev, araba, iş vb.). Bu maddi kaynaklar ile ilgili belirli tecrübeler yaşandıkça (lived experince), bunlar kişinin kendisinin (self-concept) bir parçası haline gelecektir. Mevcut maddi kaynakların kişinin hayatından aniden çıkması, kişinin kendini psikolojik olarak engelli olarak hissetmesine neden olacaktır. Çünkü kişinin kendini (self-concept) oluşturduğu yaşam deneyimleri bu maddi kaynaklar üzerine kurulmuş bir şekildedir. $\mathrm{Bu}$ teoride; kişinin sahip olduğu maddi ve oluşturduğu sembolik kaynaklar arasındaki etkileşim ile, kendini irdeleyip, izleyip ve onaylayıp kimliğini oluşturduğu iddia edilmektedir (Jackson, 2004). Bu bağlamda sembolik benlik tamamlama teorisindeki maddi kaynaklar, kişisel kimlik oluşumda etkilidir, dolayısıyla bu teorinin bireysel düzeyde incelenmesine olanak tanımaktadır.

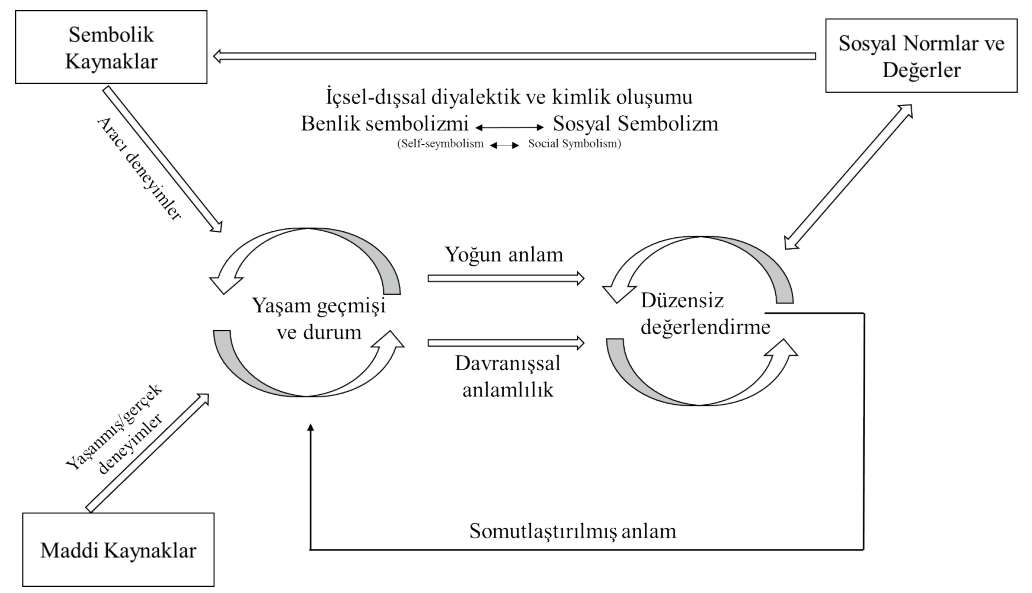

Şekil 8: Sembolik Benlik Tamamlama Teorisi (Elliott ve Wattanasuwan, 1998)

7 Tüketim psikolojisi ve sosyolojisine göre maddi mallar (material goods) kimlik oluşumunda çok ciddi rol oynamaktadır. 
Rasyonel seçim karşıtı teoriler kapsamında, Simon (1957) rasyonel seçim varsayımlarından ilki olan seçimin rasyonel olmasını, bireyin zihinsel kısıtları nedeniyle, sağlanması mümkün olmayan bir varsayım olarak değerlendirmektedir. Bireyin sınırlı rasyonelliğinden başka, bireyin her davranışını sistematik bir karar verme sürecinden geçirerek düzenlediğini varsaymanın mümkün olmadığını iddia etmektedir. Tversky ve Kahneman (1974) ise, bireyin bazı seçim ve davranışlarının rasyonel olmaktan öte tamamen rutin ve alışkanlıklarının etkisiyle şekillenebileceği eleştirisinde bulunmaktadır. Ancak bu rutin ve alışıldık davranışların da öncesinde bir bilişsel değerlendirme sürecinin yer alması, bu davranışların da bu çalışma kapsamında birey temelinde değerlendirilmesine olanak tanımıştır.

Etzioni (1988) duyguların bazen rasyonel seçimin önüne geçeceğini belirterek seçimin rasyonel olmasını eleştirmiştir (Evinde kedi besleyen birinin zahmet ve maliyetine rağmen bu davranışı sürdürmeye devam etmesi gibi.) Duygusal bir tatmin için sergilenen davranışın da yine fayda maliyet analizi sonucu oluştuğu söylenebilir. Sadece burada fayda somut değil soyut bir nitelik taşımaktadır. Dolayısıyla duyguların rasyonel seçimin önüne geçebileceği ancak içerisinde yine bireyin kendi konusundaki analizi içermesinden dolayı bireysel davranış temelinde incelenmesi uygun görülmektedir. Bireylerin sınırlı rasyonelliği, kimi zaman alışkanlıklarıyla, kimi zaman ise duygularıyla hareket etmesinden dolayı her zaman rasyonel davranış gösteremeyeceği Tablo 1'de rasyonel seçim teorisinin birinci varsayımına eleştiri olarak gösterilmiştir.

Bireylerarası Davranış Teorisi (Theory of Interpersonal Behavior), Triandis (1977) tarafından literatüre kazandırılmış olup, hem rasyonel seçim teorisi kapsamında (bireylerin kendi çıkarları temelinde davranışlarını düzenlediğine) hem de rasyonellik karşıtı teoriler çerçevesinde (bireylerin duyguları ve alışkanlıkları doğrultusunda davranışlarını düzenlediğine yönelik) bir model sunmaktadır. Bu yönüyleher iki kapsamda da birey davranışı bireysel çerçevede incelenebileceği için davranışın bireysel boyutunda ele alınıp değerlendirilmiştir. Nedenli eylem teorisindeki (Ajzen ve Fishbein, 1980) bireylerin çıktı konusundaki inançları ve bu çıktının değerlemesi sonucundaki bireydeki önemi boyutları, bireylerarası davranış teorisi kapsamında bulunmakta olup, bu boyutların bireyin tutum ve davranışlarına yansıyacağından bahsedilmektedir. Diğer taraftan bu teoride, bireyin sıklıkla tekrarladığı önceki davranışlarının, alışkanlığa dönüşmesiyle, bireyin davranışlarını düzenleyeceğinden bahsedilmiştir. Ayrıca yine rasyonellik karşıtı teoriler başlığı altında incelenebilecek duyguların da davranışları etkilediğine yönelik duygu boyutunu modelde görmek mümkündür (Şekil 9). 


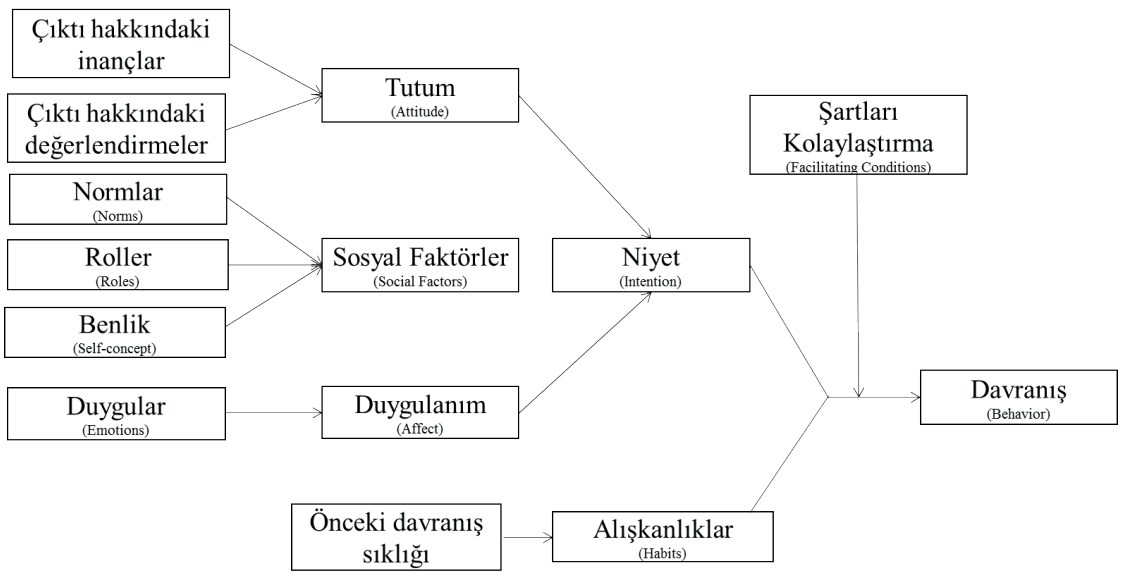

Şekil 9: Bireylerarası Davranış Teorisi (Triandis,1977)

Ölander ve Thogersen'in (1995) Motivasyon Firsat Yetenek Modeli (The Motivation-Opportunity-Abilities Model), Ajzen ve Fishbein'in (1980) Nedenli Eylem Teorisine kabiliyet ve fırsatların dahil edilmesiyle ortaya çıkmıştır. Ölander ve Thogersen'in (1995) bu model ile tüketicilerin çevre dostu davranışlarını açıklayı amaçlamışlardır. Dolayısıyla bu model, hem bireylerin kendi çıkar ve faydaları doğrultusunda, hem de alışkanlıkları doğrultusunda davranışlarını belirleyeceklerini iddia ederek, birey davranışlarını açıklamada bireysel bir perspektif oluşturmaktadır. Modelde nedenli eylem teorisi ve planlanmış davranış teorisine benzer şekilde bireylerin inançları hakkındaki değerlendirmelerinin tutum ve davranışlarına yansıyacağ1 gösterilmiştir. Bununla birlikte bireyin sahip olduğu yeteneklerinde, bireyin ilgili konudaki bilgi düzeyi ve alışkanlıklarının davranışsal niyetlerin davranışa dönüşmesinde düzenleyici etkisinin olduğundan bahsedilmiştir. (Şekil 10).

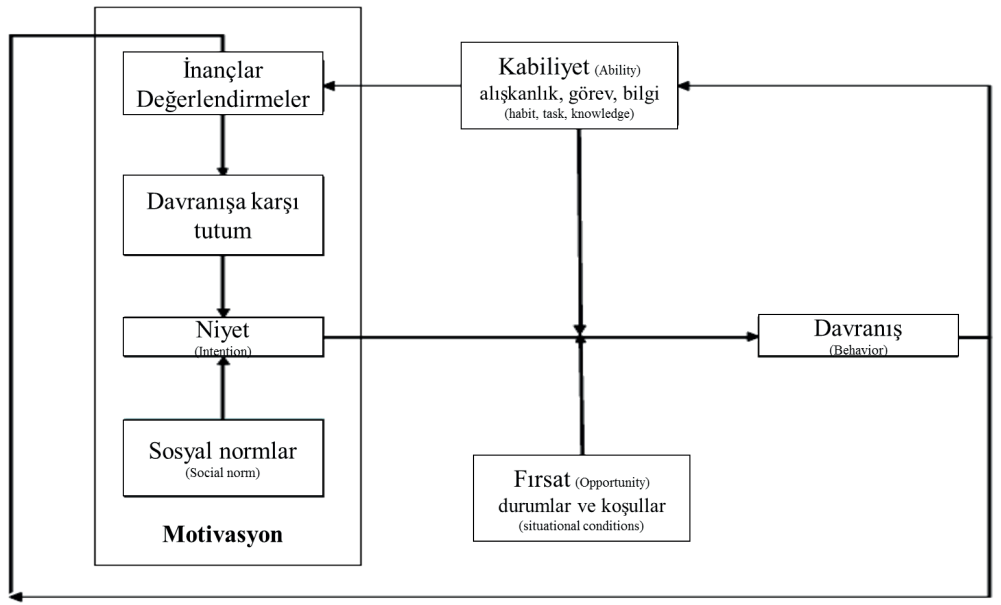

Şekil 10: Motivasyon Fırsat Yetenek Modeli (Ölander ve Thogersen 1995) 
Bilişsel Çaba - Kontrol, Otomatikleşme ve Sezgisel Yaklaşım (Jager, 2003) bireylerin davranışlarını bireysel çerçevede ele alan ve bireylerin alışkanlıkları temelinde davranışlarını düzenleyeceğini iddia eden bir yaklaşımdır. Önceki sosyal psikoloji uzmanları bireylerin zihinsel süreçlerini "otomatik" veya "kontrollü" olarak tanımlamıştır (Johnson ve Hasher, 1987). Kontrollü süreç, niyet, kontrol ve dikkat kaynaklarının en verimli şekilde kullanılmasıdır ve bilişsel çaba ile farkındalık gibi süreçleri içerir (Bargh, 1994). Otomatik sürecin ise, bu tip özellikleri içermediği iddia edilir. Otomatik ve kontrollü sürecin bilişsel süreçleri konusunda açık bir ayrım yoktur. Kontrollü sürecin öğrenmeyle otomatik sürece dönüştüğü kabul edilmektedir. Temelde zihinsel bir sürecin hem kontrollü hem de otomatik bir şekilde oluştuğu gerçektir (Kahneman ve Treisman, 1984; Logan ve Cowan, 1984; Bargh, 1994). Kontrol ve otomatiklik arasında bir yerde deneyimlerle öğrenme bulunur. Deneyimlerle öğrenme bilişsel düşüncelerin yayılımına izin veren basit bilişsel işaretlerdir. Müşterilerin basit sinyaller temelinde (fiyat veya marka) seçim yapması, rutin ve alışkanlıklar temelinde açıklanır ve deneyimlerden öğrenmeye örnek olarak gösterilebilir ${ }^{8}$. İşe gitmek için yola çıkmak, aynı marka kahveyi içmek, 1şıkları açmak, televizyonu kapamak vb. gibi rutin aktiviteler az bilinçli düşünce sonras1 ortaya çıkarlar. Rutin davranışların özelliği yüksek düzeyde otomatikleşmesidir (Jager, 2003). Rasyonel seçim teorisinin karşısında yer alan alışkanlık davranışları ise Simon'ın (1975) prosedürel rasyonalite9 kavramı kapsamında açılanmaktadır. Rasyonel seçim teorisi kararın içeriğine ve bunun kişiye olan fayda ve maliyetine odaklanırken, prosedürel rasyonalite karar verme sürecine odaklanmaktadır (Ayyıldız Ünnü N.A. 2014). Jackson (2005) prosedürel rasyonaliteyi, bireylerin bilişsel yetenek ve kısıtları 1şığında davranışları seçmede kullandıkları prosedürler olarak tanımlar ve bilişsel çaba-kontrol-otomatikleşme yaklaşımını Şekil 11'deki gibi gösterir. Dolayısıyla organizmanın benzer bir davranışı defalarca yapması sonucu oluşan alışkanlık temelli davranışlar kısa süreli bir bilişsel süreçten geçerek sergilenen davranışlar olarak tanımlanabilir.

8 Burada bilişsel çaba ve otomatiklik arasındaki dengeyi sağlayan 3 temel faktör vardır (Jackson, 2006)

- Kontrol derecesi: Karar verenin karara katılma düzeyi arttıkça kontrol derecesi artacaktır.

- Kararın karmaşıklığı arttıkça bilişsel çabada artış gözlenir. Bu karmaşıklık karşılaşığımız firsatların büyüklüğü ile ilişkilidir. Fırsatın özellikleri arttıkça sonucu tahmin etmek o kadar güçleşir, farklı kişisel amaçlar arasındaki denge değişir.

- Kararın sınırlarının genişliği bilişsel çabada artışa neden olacaktır. Zaman, bilişsel kapasite, bilgiye erişim karar almada tamamen bilişsel bir kontrol sağlamayı kısıtlayacaktır. Zaman baskısı altında bireyler basit ve daha önce tecrübe ettiği kararları almaya meyilli olacaklardır.

$9{ }^{* *}$ Prosedürel rasyonalite sınırlı rasyonelliğin temelini oluşturan bir kavramdır. 


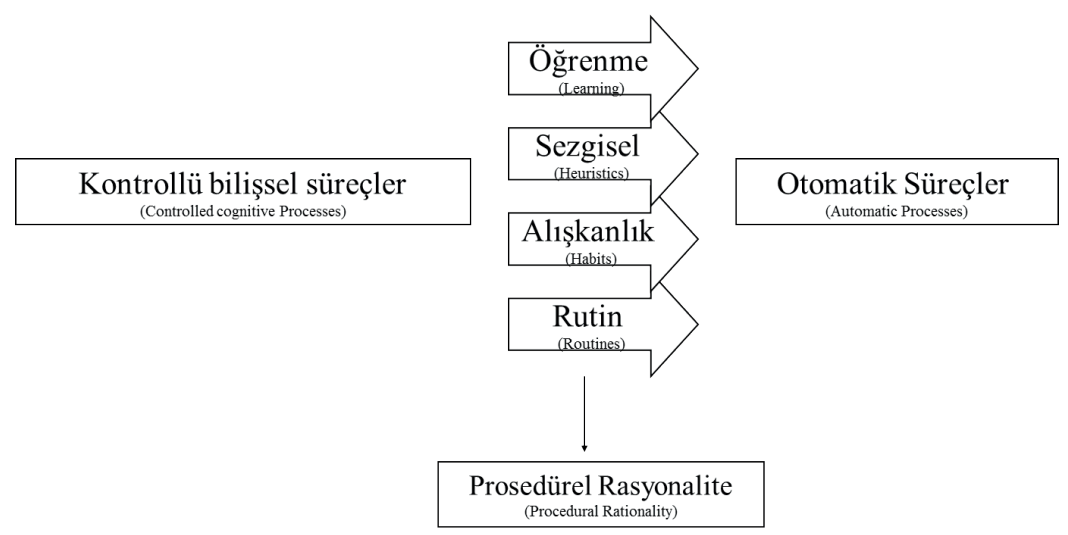

Şekil 11: Bilişsel Çaba - Kontrol, Otomatikleşme ve Sezgisel Yaklaşım (Jackson, 2005).

Tversky ve Kahneman'ın (1974) çerçeveleme, önceliklendirme ve yanlılık yaklaşımı (Framing, Priming and Biasing Approach); rasyonellik karşıtı teorilerin "bireyin her zaman kendi çıkarları doğrultusunda analiz yaparak davranışlarını düzenleyemeceği, belirli zamanlarda bilinçsizce belirli davranışlar sergileyeceği" fikrini doğrular şekilde, davranışı bireysel temelde değerlendirerek açıklayan bir yaklaşımdır. Jackson'ın (2005) ifade ettiği gibi, bireyler belirli olay ve durumları, farklı bakış açılarına dayandırarak belirli çerçevelere sokarak açıklamaktadır. Bu çerçeveleme faktörü çoğu zaman bir dizi bilinçsiz işaretler oluşturur. Bu işaretler ise belirli bir seçimi yapmak veya yapmamak konusunda bilişsel tepkilerin oluştuğu yanlılığın fonksiyonudur. Yapılması gereken seçimde neyin seçileceği ne kadar açık olursa olsun, her birey bu seçimi seçeneklere karşı oluşturduğu tepkileri çerçeveleyerek yapacaktır. Çerçeveleme kavramı prosedürel rasyonellik kavramı çerçevesinde incelenebilir. Prosedürel rasyonelliğin amacı karar vermede bilişsel çabayı en aza indirgemektir. Bu yaklaşım, başarmak konusundaki kararların kaybetmek konusundaki kararlardan daha farklı şekilde önceliklendirildiğini ve çerçevelendiğini göstermiştir (Tversky ve Kahneman, 1974).

Rasyonellik karşıtı teoriler çerçevesinde davranışı birey düzeyinde açıklayacak teorilerden bir tanesi Giddens'in $(1976,1984)$ yapılandırma teorisidir. Şekil 14'de Jackson'ın (2005) tarafından da gösterildiği gibi, Giddens bireylerin davranışlarını günlük/pratik (practical) ve düzensiz (discursive) bilinç temelinde açıklamaktadır. $\mathrm{Bu}$ teorideki günlük/pratik bilinç, insanların neyi nasıl yapacaklarına yönelik günlük bilgileridir. Bu tür bilinç bireylerin neyi nasıl yapacağına yönelik kabul edilmiş bilginin içeriğine bağlıdır. Giddens (1979) birçok bireyin pratik bilincini kullanarak rutin durumdaki davranışlarını düzenlediğini öne sürmektedir.

Prososyal davranış; davranışı sergileyen bireyin (aktör), başka bir bireyi odak alarak veya ona faydası dokunacağı beklentisiyle gerçekleştirdiği davranışlar 
olarak tanımlanmaktadır (Sorrentino ve Rushton, 1981). Oldukça genel yapılan bu tanımın yanında prososyal davranışı; davranışı sergileyenin motivasyonuna göre sinırlandirarak tanımlayanlar da mevcuttur (Berkowitz, 1972; Krebs, 1982). Prososyal davranış bazı araştırmacılar tarafından farklı bağlam ve durumlarda farklı kapsamlarda incelenmiştir. Örneğin Eisenberg vd. (1981) yardıma ihtiyacı olan birinin bizden yardım istediğinde spontane bir şekilde yardım ettiğimizi iddia etmektedir. Carlo vd. (1991) ise, durumun duygusal yönden bizi etkilemesine göre bireylere yardım ettiğimizden bahsetmektedir. Fabes ve Eisenberg (1998), bireylerin diğer bireylere karşı olan pozitif davranışlarını; belirli içsel (kişisel normlar, prensipler veya sempati duyulanlar) ve dişsal (diğer insanlardan onay almak vb.) motivasyonlarla yaptığını göstermektedir. Örgüt düzeyinde prososyal davranışı, başkalarının refahı ve bütünlüğünü sağlamak ve sürdürmek için yürütülen olumlu sosyal eylemler biçiminde tanımlamak mümkündür (Öcal ve Sarnıç, 2017). Bu tanımlardan da görüdüğü gibi, prososyal davranış kavramının ele alındığı kapsamlar prososyal davranışın farklı boyutlar içerdiğini göstermektedir. Myers (2015) de, karşılık beklentisiyle ve koşulsuz yardımseverlik ile sergilenen olmak üzere prososyal davranışı iki şekilde sınıflandırmıştır. Koşulsuz yardımseverliğin getirdiği manevi tatmin açısından değerlendirildiğinde, prososyal davranışı bireysel boyutta görmek mümkündür. Walster ve Piliavin'in (1972) prososyal davranışı, karşılığında herhangi bir maddi veya sosyal ödül beklemeden tamamen gönüllü olarak sergilenen davranış olarak tanımlaması doğrultusunda, prosoyal davranışın yine bireye manevi tatmin sağlaması, kendini iyi hissettirmesi açısından bireysel yönünün olduğunu söylemek mümkündür. Diğer taraftan, Carlo ve Randal (2002), önceki çalışmalarda ayrı ayrı değerlendirilen dört ayrı prososyal davranışa iki tane daha ekleyerek, prososyal davranışı altı boyut ile açıklamıştır. Bunlar; özgeci (altruistic), itaatkar (compliant), duygusal (emotional), kamusal (public), gizli (anonymous) ve acil (dire) prososyal davranışlardır. Duygusal (emotional) prososyal davranış, duygusal olarak etkilenmiş(arousal effect) veya yardım edilmesi gerektiğini hissettiren durumlarda olan bireylere yardımı içerir. Diğer taraftan her durum her bireyde aynı duygu durumunu oluşturmayabilir. $\mathrm{Bu}$ durum bireylerin kendi duygularını dengeleme/ düzenleme kabiliyetlerine, kendilerini veya başkalarını ne kadar düşündüklerine bağlı olarak değişecektir (Fabes ve Eisenberg, 1998). Bireyin yardıma ihtiyacı olan kişiye yardım etmediğinde, bu durum bireye stres unsuru olabilir veya bundan rahatsızlık duyabilir. Yardım ettiğinde duygusal bir tatmin de hissedebilir, çünkü birey duygusal olarak yardıma ihtiyacı olan kişiden etkilenmiştir. Ancak burada bireyin kendi duygu durumunu dengelemesi nedeniyle yardımı söz konusudur ve dolayısıyla duygusal prososyal davranış bireysel düzeyde değerlendirilebilecek bir davranıştır. Sadece yardıma ihtiyacı olan bireyi düşünerek yardım edilmesi, prososyal davranışın özgecilik boyutunu açıklamaktadır. Ancak araştırmacılar aşağıda bahsi geçen 3 farklı durumdaki davranışın, özgecil prososyal davranış olup olmadığı hakkında bir karara 
varamamıştır. Bunlardan ilki genetik geçiş temelli sempatidir (heritability of of sympathy) ve bireylerin genetik olarak devamlılığının sağlanması için, kendi akraba ve yakınlarına yardımını içerir (evrimsel psikoloji temelinde açıklanan) (Matthews vd, 1981). İkincisi çocukluktan beri süregelen bir prososyal tutum içinde olmanın, bu davranışı ileri yaşlarda da sergileme konusunda eğilimli olmayı getirmektedir (Franzoi ve Davis, 1994; Eisenberg vd., 1981). Üçüncüsü ise, bireylerin kişilik özelliklerinin etkisiyle prososyal davranışlar sergilemesidir (Carlo vd., 1991; Staub, 1978). Bu tartışmadaki 3 davranışın kendi neslini devam ettirme, alışkanlık ve kişisel özellikler içermesi nedeniyle tarafımızdan bireysel düzeyde ele alınması gerektiği düşünülmektedir. Ancak genel olarak özgecil prososyal davranışta bulunan bireyin motivasyonu, buradaki yardım davranışını bireysel boyutunun yanında sosyal ve normatif boyutta da inceleyebileceğimizi göstermektedir. Çünkü prososyal davranışın ortaya çıkmasındaki iki temel motivasyon sempati (sympathy) ve içsel normlar/ prensiplerdir (internalized norms/ principles). Empati başka birinin duygusal durumu nedeniyle bireyde oluşan duygusal bir tepkidir ve bu tepki bu durumla uyumludur (Fabes ve Eisenberg, 1998). Teorisyenler empatinin, ya sempatiye (diğerlerinin duygusal durumlarını algılamak ve anlamak temelinde diğerlerini düşünmek ve onlar için endişelenmek - odak yönelim diğerlerinde) ya da kişisel strese (diğerlerinin duygusal durumlarını algılamak ve anlamak temelinde olan itici/ zit bir duygusal tepki- odak yönelim kişinin kendisinde) neden olacağını belirtmektedir (Fabes ve Eisenberg, 1998). Araştırmacılar sempatinin; diğer bireylerin streslerini azaltmak veya ortadan kaldırmak amaçlı bir motivasyon olduğunu, kişisel stresin ise; bireyin kendi stresini azaltmak veya ortadan kaldırmak amaçlı bir motivasyon olduğunu belirtmektedirler (Batson ve Shaw, 1991; Hoffman, 1991). Dolay1siyla empati gösteren birey, yardıma ihtiyacı olan biri karşısında, kendi stresini azaltma nedeniyle o kişiye yardım ediyorsa, bu tip bir davranış özgecil prososyal davranışın bireysel düzeyde incelenmesine olanak tanıyacaktır. Gizli (anonymous) prososyal davranış, yardım edenin ve yardım edilenin birbirini bilmemesi durumudur (Carlo vd., 2003). Burada yardım eden kişinin iç huzuru, birine yapılan yardımın yerini bulması ve onun gururun kırılmaması önemlidir. Prososyal davranışın diğer bir türü olan acil (dire) prososyal davranış, acil ve kriz durumlarında bireylere yardım etme davranışını açıklar (Carlo ve Randal, 2002). Birey aynı acil durumun kendisinin de bir gün başına gelebileceğini düşünerek kurduğu empatik bağlamla yardıma ihtiyacı olan bireylerin yardımına koşabilir. Bununla birlikte, acil durumda yardım etmemenin verdiği stres kişiyi rahatsız edebilir. Benzer şekilde birey, acil bir duruma müdahale ettiğinde kendini değerli hissedebilir. Diğer taraftan, başka insanların gözü önünde, başkalarına fayda sağlamak için yapılan ve sosyal boyutu olan kamusal prososyal davranış kapsamında seyirci etkisi (bystander effect) bireysel boyutta irdelenebilir (Myers, 2015), birey bu zahmete katlanacağına (fayda-maliyet analizi yapılarak) başkalarından bu davranışı göstermesini bekleyebilir, başkaları yapsın diye düşünebilir. İtaatkar 
(compliant) prososyal davranış ise, yardıma ihtiyacı olan bireyin sözlü veya sözsüz isteğine karşı bir cevap niteliğinde olan spontane bir yardım davranışıdır (Eisenberg vd., 1981). Bu durumda yardım ihtiyacının geri çevrilmesinin verdiği rahatsızlık veya yardım etmenin verdiği bir duygusal tatmin nedeniyle bireyler prososyal bir şekilde davranmış olabilir. Prososyal davranışın bireyin stresini azaltmak, kendini iyi hissetmek ve değerli görmek gibi bireysel boyutu söz konusudur.

Birey davranışlarını bireysel çıkar ve tatmin temelinde açıklayan bir diğer kavram örgüt düzeyindeki yardım etme (helping behavior) davranışıdır. Yardım etme davranış1, "bireyler arası uyumun teşviki için sergilenen ve iş arkadaşlarının iş ile ilgili sorunları çözmesine yardımcı olacak gönüllü davranışlar olarak tanımlanır" (Podsakoff vd., 2000). Tanımdan da anlaşılacağ1 üzere birey bu davranış1, kendi isteğiyle diğer bireylerin yararına sergilemektedir. Ancak yardım etme davranışı gösteren kişiyi bu davranışa iten motivasyonu çok iyi analiz etmek gerekir. Bu davranış her ne kadar gönüllü olarak sergilenen bir davranış olarak görülse de, özellikle örgüt düzeyinde sergilendiği için, bireyin yardım etmesinin altında yatan nedenleri irdelemekte fayda vardır. Tanımda bahsedilen 'bireyler arası ilişkilerinin geliştirilmesi' amaçlanan bu davranışta; birey sosyal bağlamda parmakla gösterilen biri olmak, ya da bilgisinin yeterliliğini göstermek veya birilerinin gözüne girmek amacıyla başkalarına yardım ediyor olabilir. Diğer taraftan örgütte çalışma arkadaşlarına yardımcı olan birinin elde ettikleri ve yardım etmeyenlerin kaybettiklerini değerlendirerek de örgütte kendi çıkarını düşünerek de yardım etme davranışını sergileyebilir. Hangi durumlarda yardım edeceği hangi durumlarda etmeyeceğini önceki tecrübelerinden de öğrenmiş olabilir. Birey önceki tecrübe edilen olayda yardım etmenin faydası, etmemenin ise maliyetini veya hissetiği rahatsızlığ1 (Myers, 2015) defalarca tecrübe etmesi ile, benzer durumlar karşısında kişilere yardım etme/etmemeyi alışkanlık haline getirmiş de olabilir. Ya da yardım etmemenin kendisine neye mal olacağını değerlendirip ona göre yardım etme davranışında bulunabilir. Diğer taraftan, Aristo bireyin doğasından gelen bir iyilik halinin olduğundan bahseder ve yardım eden kişilerin, edilenlerden daha çok pozitif duygular hissettiğini iddia eder ${ }^{10}$. Bu bakış açısına göre, birey yardım etmekten bireysel bir haz duyduğu veya duygusal bir tatmin hissettiği için yardım etmeyi tercih edebilir.

İlk olarak Hirschman (1970) tarafindan ortaya atılan fikrini açıkça söyleme davranış1, organizasyon bünyesinde iyi işlemeyen herhangi bir konuyu kabul etmek yerine her türlü baskıya rağmen bu konuda fikrini beyan etmek anlamına gelir (Parker, Collins ve Grant, 2008). Birey fikrini söylediğinde kendini mutlu hissediyorsa, bu davranışı kişisel/ duygusal tatmin sağladığından ötürü sergilediği için bireysel fayda temelinde değerlendirilebilecek bir davranıştır. Birey fikrini söylediğinde bir takım menfaatler elde edeceğini düşünüyorsa ya da kendini ispat etmek, önemli

10 https://psychology.iresearchnet.com/social-psychology/prosocial-behavior/helping-behavior/ 
göstermek istiyorsa fikrini söyleme davranışı bireysel boyutu olan bir davranış olarak nitelendirilebilir.

Hem bireysel (organizational citizenship behavior for individual-OCBI) hem de örgüt (organizational citizenship behavior for organization-OCBO) boyutlarında değerlendirilen örgütsel vatandaşlık davranışı (organizational citizenship behavior) da incelememize dahil edilebilir. Çalışanların birey veya örgüt yararına, iş tanımda bulunmayan pozitif davranışlarda bulunması şeklinde Organ (1990) tarafından tanımlanan örgütsel vatandaşlık davranışı özgecilik, centilmenlik, sivil erdem, vicdanlılık ve nezaket boyutlarıyla açıklanmıştır. Centilmenlik, örgütte karşılaşılan güçlükler ve sıkıntılar karşısında şikayet etmeden ve olumlu bir tutum içerisinde çalışmaya istekli olmayı ifade eder. Bu boyutta, sorunları problem etmeme anlayışı vardır (Allison, Voss ve Dryer, 2001; Schnake ve Dumler, 2003). Sivil erdem ise, örgütün çıkarlarını en üst düzeyde gözeterek, mesleki ve sosyal anlamda örgütün işlevlerini destekleme, örgüte gönüllü olarak katılma gibi örgütle ilgili olan davranışları içermektedir (Allison vd., 2001). Sivil erdem boyutu, örgütün politik yaşamına katılım göstermeye dönük etkinlikleri içerir (Deluga, 1994). Nezaket, örgütte diğer işgörenlerin işlerini etkileyecek problemlerden sakınmalarına yardımcı olacak davranışları anlatır (Podsakoff ve MacKenzie, 1994). Ayrıca, bu boyut, bireylere işlerini etkileyecek davranışlarda bulunmadan önce düşünceli davranmaları ve kontrollü hareket etmeleri için yardımcı olmayı içermektedir (Allison vd., 2001). Örgütsel vatandaşlık davranışı her ne kadar örgüt yararına ve isteğe bağlı bir davranış olarak değerlendirilse de; birey bu davranışları öne çıkmak, kendini göstermek amacıyla gerçekleştiriyorsa, örgüt yararına gibi görünen bu davranışlar, bireyin kendi çıkarlarına hizmet etmesi nedeniyle bireysel düzeyde değerlendirilebilir. Örgütün politik yaşamına katılım göstermeye dönük faaliyetler (Deluga, 1994) (sadece örgütün yararını düşünmek), kimi zaman etik kuralların ihlali veya çevresel duyarlılığın ikinci plana atılması gibi sonuçlar doğurabilmesine rağmen, kişisel fayda maliyet analizi yapıldığında bireysel bir boyut içerdiği düşünülmektedir. İşe devam etme, çalışma zamanını etkili kullanma ve iş ortamında belirlenen çeşitli kurallara bağlllık gibi davranışlara öncelik vermek ise; örgütün biçimsel kurallarına uygun davranmak olup aksi halde bireyin çıkarlarının zedeleneceği düşüncesiyle bireysel düzeyde incelenmesi uygun görülmüştür. Diğer taraftan daha önce prososyal davranışta açıklandığı gibi, örgütsel vatandaşlık davranışının özgecilik tarafı da birey yönelimli olarak açıklanabilir. Her ne kadar özgecilik kavramı hiçbir karşılık beklemeden yardımı içeriyorsa da, birey çalışma arkadaşlarına yardım etmesinden duyduğu duygusal bir tatmin hissiyle bu davranışı sergiliyor olabilir. Başka bir bakış açısı ile; birey yardım etme davranışını önceki deneyimlerinden öğrenmiş ve belirli durumlar için bunu alışkanlık haline getirmiş olabilir. Diğer taraftan, birey, örgüt içinde her şeyi sorun edinen biri olarak görünmek istemeyebilir, örgütün faaliyetlerinin destekleyerek örgüt içinde geleceğini teminat altına almayı düşünebilir. Bu yönleriyle 
değelendirildiğinde, örgütsel vatandaşlık davranışının bireysel boyutundan söz etmek mümkün görünmektedir.

Daha sonra örgütsel vatandaşl1k davranışı, çevreci örgütsel vatandaşlık davranışı (çevreci ÖDV) kapsamında Boiral (2009) tarafından değerlendirilmiştir. Çevreci örgütsel vatandaşlık davranışı (Organizational citizenship behavior for environment) ise "biçimsel görev tanımlarında belirtilmeyen, çalışanların örgütü ve/veya toplumu daha sürdürülebilir hale getirmek için sergiledikleri bireysel çabaların ve gönüllü davranışların toplamı" şeklinde tanımlanan bir kavramdır (Lamm, Tosti-Kharas ve Williams, 2013). Boiral (2009), Organ'ın (1990) ortaya koyduğu örgütsel vatandaşlık davranışı boyutlarını çevreci perspektifte ele alarak çevreci örgütsel vatandaşlık kavramını tanımlamış ve çevreci örgütsel vatandaşlık davranışının boyutlarını tekrar belirlemiştir. Buna göre çevreci örgütsel vatandaşlık davranışı eko-girişim, eko-sivil katlım ve eko-yardım olmak üzere 3 boyut ile açıklanmıştır. Çevreci ÖVD’nın, bireyi çevreci davranış sergilediğinde duygusal olarak tatmin ettiği bir gerçektir. Çünkü birey insanlık ve doğa için iyi davranışta bulunmuştur ki bu da bireyin kendisini iyi hisedeceği bir davranıştır. Diğer taraftan, Ones ve Dilchert (2012) ise, çalışanların tüm çevreci davranışlarının (pro-environmental behavior) isteğe bağlı olmadığını \%13-29 luk kısmının kendi yerine getirdiği görevin yükümlülüğü olduğunu iddia etmektedir. Bu sonuç, çevreci vatandaşlık davranışının bireylerin kendi görevlerini yerine getirmediklerinde o işe devam edemeyeceği kaygısıyla da sergilenebileceğini göstermektedir. Başka bir açıdan da, bireylerin çevre duyarlılıkları önceden öğrendikleri ile oldukça ilişkilidir. Sürekli kağıtları geri dönüşüm kutusuna atan bir kişi bu davranışı rutin ve alışkanlıkları doğrultusunda gerçekleştirmiş olabilir. Hem görev yükümlülükleri hem de alışkanlıklar açıdan bakıldığında çevreci örgütsel vatandaşlık davranışı bireysel düzeyde incelenebilir.

Etik davranışın da bireysel düzeyde incelenebilecek yönleri mevcuttur. Örneğin makyavelist kişilikli bireyler etiğin mutlak değil durumsal yönünün olduğunu savunur (Leary, Knight ve Barnes, 1986). Yani bireyler kendi çıkarları ile uyumlu durumlarda etik davranabilirler. Ayrıca bireyin etik davrandığında kendini iyi hissetmesi veya önceki öğrendiklerinden etik dışı davranışın uzun dönemli fayda getirdiği vb düşünceler, bireyi kendini düşünerek etik davranmaya itebilir. Çünkü bireyin kişiliği ve geçmişteki öğrendikleri kendi etik felsefesini ve modellerini oluşturmasına olanak tanımaktadır (Stead, Worrell ve Stead, 1990). Bu durumda etik davranmamayı birey kendisine yakıştıramaz ve etik davranmakla da gurur duyar.

Bireylerin kendi çıkarlarını düşünerek belirli fayda-maliyet analizleri sonucu davranışlarını düzenlemeleri, bu çalışma kapsamında, davranışın bireysel boyutta ele alınıp değerlendirilmesine olanak tanımıştır. Özellikle rasyonel seçim teorisinde belirtilen çıkarcı ekonomik insan modeli davranışın birey temelli boyutunu 
oluşturmuştur. Diğer taraftan rasyonellik karşıtı bazı teoriler, bireyin her zaman belirli analizlerle davranışlarını belirlemediği, çoğu zaman alışkın ve rutin olan davranışları tercih ettiğini veya duygularıyla hareket ettiğini savunmaktadır. Ancak bu alışkanlıkların da bireyin sergilediği önceki davranışlar ile ilintili olması, daha önce bilişsel süreçten geçirilerek sergilenen davranışların alışkanlığa dönüşmesi nedeniyle, birey temelinde açıklanabilecek davranışlardır. Bireyin duygularıyla hareket etmesinde ise bireyin mevcut davranışında duygusal bir tatmin hissetmesi nedeniyle ilgili davranışı göstermesi söz konusudur. Bu noktada birey kendini görmek istediği yere göre geliştirdiği kişisel norm ve değerler çerçevesinde de hareket edebilir. Benzer şekilde burada da bireyin duygusal bir tatmini bulunmaktadır. Kısaca çalı̧̧mamızda davranışın bireysel boyutu; bireyin maddi veya manevi çıkar elde etmek için kimi zaman bireysel düzeyde fayda maliyet analizi sonucu sergilediği, kimi zaman haz aldiğl, yapmaktan mutlu olduğu veya rahatsızlık ve huzursuzluk duymamak için ya da kendini iyi ve değerli hissettiği için yaptı̆̆l, kimi zaman ise önceden öğrendiği hatta alışkanlık veya rutin haline getirdiği davranışlar olarak tanımlanmışıtı.

\section{Davranışın Sosyal Boyutu}

Herhangi bir davranışın bireyin kendisine bağlı olarak değişeceği, önceki kısımda literatürdekibelirliçalışmalarlaaçıklanmıştır.Diğertaraftan, literatürdeilgilidavranışın belirli bir yerde sergilenmesinin kişiye bağlı olduğu kadar bulunulan ortama da bağlı olduğunu belirten birçok çalışma bulunmaktadır (Ajzen ve Fishbein, 1980; Cialdini vd., 1990; Ajzen, 1991; Cialdini vd., 1991). Bu düşüncenin temeli sosyal psikoloji alanının temelini oluşturan sosyal bilişsel teoriye dayanmaktadır. Sosyal psikoloji "insanların birbiri hakkında neler düşündüğü, birbirini nasll etkilediği ve birbiri ile nasıl ilişki kurduğunu inceleyen bilim dalıdır" (Myers, 2015:4) Benzer şekilde, Bandura sosyal bilişsel teori ile bireylerin koşullama veya önceki tecrübelerinden öğrendiği gibi, başkalarının tecrübelerinde de öğrenerek davranışlarını buna göre düzenlediğini savunmaktadır. Blau (1964) ise, ortaya attı̆̆ sosyal mübadele teorisi ile bireylerin belirli davranışları karşıdakilerden aynı/benzer davranışı beklediğinden dolayı sergilediğini iddia etmektedir. (Burada bireyin bulunduğu topluluk tarafindan onaylanmak veya dişlanmamak istemesi söz konusudur. Çoğu zaman bulunulan topluma uyum sağlamayı temel alan bu davranışların temelinde bireyin gözettiği bir sosyal çıkar vardır ve birey sosyal düzeyde bir fayda-maliyet analizi sonucunda hangi davranışın sergilemesi gerektiğine karar vermektedir. İzlendiğini, gözlendiğini düşünen ya da farkında olan birey sosyal ortama uyum sağlayacak, sosyal normlara uygun davranmaya çalışacaktır. Sonuç olarak, bireylerin içinde bulundukları topluluklar kişinin davranışlarını belirlemede etkili olacağı söylenebilir. Aşağıda ele alınan teori, yaklaşım ve modellerde davranışın sosyal boyutu bu kapsamda incelenip değerlendirilmiştir. 
Bandura'dan sonra daha birçok çalışma bireylerin bulunduğu sosyal ortamın davranışa yansımasını araştırmıştır. Örneğin, sosyal bağlam (social context) ve toplumun (bireye karşı olan) (society-against individual), rasyonel olmayan seçimler yapmada etkili olduğu, rasyonel seçim teorisi çerçevesinde incelenmiştir (Homans, 1961; Elster, 1986).

Yukarıda değinildiği gibi, rasyonel seçim teorisinde; bireyin kendi fayda ve maliyetlerini değerlendirerek yaptığı seçimlerden bahsedilmiş, davranış sadece birey analiz biriminde incelenmiştir. Birey davranışlarını açıklamada birey analiz biriminin yetersizliği, bireyin bulunduğu sosyal ortamın da analiz çerçevesine alınması gerektiği eleştirisi, Tablo 1'de rasyonel seçim teorisinin ikinci varsayımına eleştiri olarak gösterilmiştir. Bu teorinin birey analiz birimi varsayımı Elster (1986), Gronovetter (1985), Zey (1992), Tajfel (1982) ve Giddens (1984) gibi yazarlar tarafindan eleştirilmiştir. Jackson (2005), birey analiz birimi varsayımını, "klasikyönetim yaklaşımı çerçevesinde yalnızca birey ele alınarak sonuçların değerlendirilmesine” benzeterek eleştirmektedir. Zey (1992) zihinsel alışkanlıklar (habits of mind) ve davranışların sosyal kültürel bağlamda ortaya çıktığını iddia etmiştir. Ayrıca bireyin sosyal psikolojik bir kimliğinin olduğunu ve bireylerin kendi (self) kavramını şekillendirirken kendini sosyal olarak konumlandırdığını belirtmiştir. Birey analiz birimi varsayımına ikinci bir eleştiri, bireylerin karar verme süreçlerinde, bulundukları sosyal ortamın belirleyici olduğu iddiası oluşmuştur (Tajfel, 1982). Bireyler kendi içinde bulundukları ortama göre farklı sosyal roller ve kimlikler edinmektedir. Aynı şekilde grup kimliği de grup davranışlarını belirleme ve grup içindeki varlığı devam ettirme sürecinde önemlidir. Dolayısıyla bu grup içi ve gruplar arası süreçler bireysel rasyonellik ihtimalini azaltan süreçler olarak değerlendirilebilir. Rasyonel seçim teorisinin birey analiz birimi varsayımı bir de sosyolojik yaklaşım - sosyal hareketler, sosyal yapılar - temelinde eleştirilmektedir. Bu eleştirilerden biri de, "Sosyal yapılar insanların davranışlarına indirgenebilseydi, ancak o zaman birey analiz birimi davranışı açıklamada yeterli olabilirdi" şeklindedir (Giddens, 1984). Sosyolojistler sosyal yapının var olmasına odaklanır ve bu yapının bireyin davranışlarını etkileyeceğini iddia eder, bireyin sosyal yapıyı etkileyeceği ile daha az ilgilenir (Polanyi, 1944; Bourdieu, 1990; Reckwitz, 2002). Sosyolojik yaklaşım, birey hareketlerine aşırı sosyallik (over-socializing) getirdiği, rasyonel seçim teorisi ise bireylerin seçimlerinde sosyalliği elimine ettiğinden (under-socializing) dolayı eleştirilmektedir.

Birçok sosyal psikolojik model insan davranışlarına bireysel bir şekilde yaklaşmıştır. Oysa deneyimler diğerlerinin ne düşündüğü, söylediği ve yaptığ́ ile bireyin kendini sınırlandırdığını göstermektedir. Bazı sosyal teoriler birey davranışlarının sosyal olarak yapılandırıldığını, dolayısıyla bireylerin davranışlarının bireysel çerçevenin ötesinde sosyal boyutu ile değerlendirilmesi gerektiğini savunmaktadır (Jackson, 2005). Bu teorilerden bazılarına aşağıda yer verilecektir. 
Şekil 3'te görülen Nedenli Eylem Teorisi (Theory of Reasoned Action) (Ajzen ve Fishbein, 1980) bireyin, diğer bireylerin ne düşündüğü konusundaki inançları ile ilgili bir değerlendirme yaparak, kendilerine özgü bir (subjektif) norm oluşturacakları ve böylece sosyal süzgeçten geçmiş bir davranış geliştireceklerinden bahsetmiştir. Bireyin kendine özgü bu normları içinde bulunduğu sosyal topluluk tarafından onay almak veya dışlanmamak için geliştirdiği söylenebilir. Nedenli Eylem Teorisinin biraz daha geliştirilmiş versiyonu olan Planlanmış Davranış Teorisinde ise; subjektif normlar sadece bireyin etrafındaki diğer kişilerin ne düşündüğü konusundaki inancı tarafından belirlenmemektedir (Madden, Ellen ve Ajzen, 1992). Subjektif normlarla birlikte, bireyin öz yeterliliğinin (bireyin herhangi bir şeyi yapabileceği konusunda kendine inanc1) sonucu davranışsal kontrolüne (bireyin bir davranışı sergileme konusundaki yeteneğini değerlendirmesi, bireyin gerekli firsat ve kaynaklara ulaşabileceği algısı) yansımasıyla, bireyin niyetini belirleyeceği ve bunun da davranışa dönüşeceği, bu teoride iddia edilmektedir (Ajzen, 1991). Yani birey herhangi bir davranış1 sergilemede, hem diğer kişilerin düşünceleri konusundaki inancı, hem de o davranış1 sergileyebileceğine (kendine) inancı etkilidir (Şekil 12). Dolayısıyla nedenli eylem teorisi ve planlanmış davranış teorisinin, birey davranışlarını bireysel perspektifte açıklamasının yanında, sosyal perspektifte de değerlendirdiği söylenebilir.

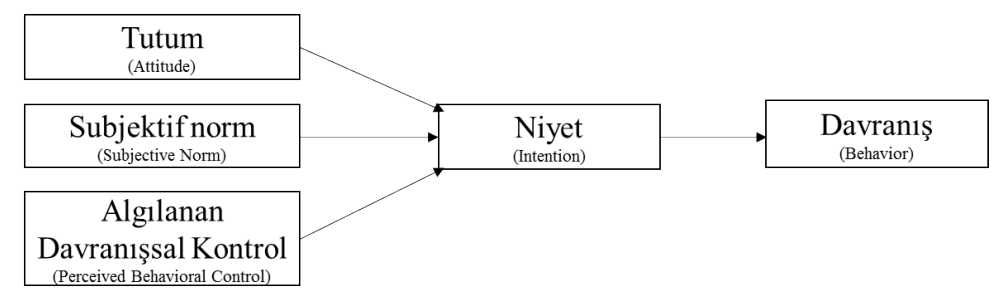

Şekil 12: Planlanmış Davranış Teorisi (Ajzen, 1991)

Bireylerin soysal bağlama (context) göre davranışlarını düzenlediğini savunan bir diğer teori Ciladi $(1990 ; 1991)$ tarafindan ortaya atılan Normatif Davranışa Odaklanma teorisidir (Focus Theory of Normative Conduct). Bu teoride, sosyal normlar, davranışları algılanan sosyal fayda ve maliyetlerine göre değerlendirmektedir. Cialdini vd. (1990), sosyal normların bireylerin geri dönüşüm konusundaki niyetleri üzerine etkisini araştırdığı çalışmasında, sosyal normları tanımlayıcı ve önleyici normlar olmak üzere iki ayrı kavram olarak ele almıştır. Tanımlayıcı normlar (descriptive norms), spesifik bir durumda, diğer bireylerin genel olarak göstereceği davranışlar konusunda bireylerin kendi algısıdır. Bu algı doğrultusunda birey; olduğu sosyal ortamdan dışlanmamak veya diğer bireylerden kabul görmek için diğerlerinin davranışlarıyla uyumlu davranışlar geliştirecektir. Bu spesifik durumlarda, hangi davranışların daha etkin ve duruma uyarlanabilir olduğunu göstermesi vasıtasıyla tanımlayıcı normlar davranışları etkiler. Önleyici normlar (Injunctive Norms) ise, herhangi bir davranışın bireyin kendi etrafındaki bireyler tarafından onaylanması veya 
onaylanmaması konusundaki algısı ile ilgilidir. Önleyici normlar, hangi davranışların sosyal ödül veya yaptırım davranışları ile karşılanacağına göre davranışlarda etki yaratır. Buradaki sosyal ödül diğer bireylerden kabul görmek, övgü almak şeklinde, sosyal yaptırım ise dışlanmak veya eleştirilmek şeklinde örneklendirilebilir. Cialdini vd. (1990) bu çalışma sonucunda; her iki normun da bireylerin geri dönüşüm niyetleri üzerine pozitif etkide bulunduğunu bulmuştur. Örneğin organizasyonda herkesin görebileceği bir yerde işyerinden ayrılırken çalışanların \%75'inin 1şıkları söndürüp gittiği ile ilgili bir afiş asılması, geri kalan \%25'in çevreci tanımlayıcı normlarını değiştirmede etkili olacaktır (Ruepert, Steg ve Keizer, 2015). Enerji kısıtlama politikası güden bir organizasyonda, çalışanların önleyici normlara uyum sağlaması ihtimali, bir çalışma arkadaşını enerji tasarrufu odaklı bir davranışı yaparken görmesiyle artacaktır (Cialdini, 2003).

Sosyal sembolik benlik (social sybolic self) teorisi, bireylerin davranışlarını sosyal kapsamda değerlendiren teorilerdendir. Şekil 13'de Jackson(2005) tarafından şematize edilen bu teori, Mead'in (1934) "her bir hareket sosyal bir duruma verilen yanıttır ve bu hareketler birleştiğinde iletişim ortaya çıkar" savı üzerine kurgulanmıştır. İletişim sosyal diyalog (social conversation) olarak adlandırılmıştır. Sosyal diyalog ise; sosyal grupların değer, tutum ve inançlarının müzakere edilmesi veya içselleştirilmesiyle bir mekanizma yaratır. Kültürel normlar da bireylerin müzakere ettiği veya içselleştirdiği diyaloglar yoluyla oluşur. Diğer taraftan birey sosyal çevresindeki sembolik anlamlar (symbolic meanings) ile diğer kişilerle etkileşim (social interaction) sağlayabilecektir. Burada kişi sembolik anlamları yorumlayarak bu anlamlar ile kendi davranışları konusunda bir mutabakat (negotiation) oluşturacaktır. Sonuç olarak birey sosyal diyaloglarla topluluktan dişlanmamak ve sembolik anlamları yorumlayarak toplum tarafından kabul görecek davranışları sergileme konusunda sosyal sembolik bir benlik oluşturacaktır. Bu benlik de, bireyin sembolik anlamları yorumlaması süreci boyunca davranışlarını etkileyecektir.

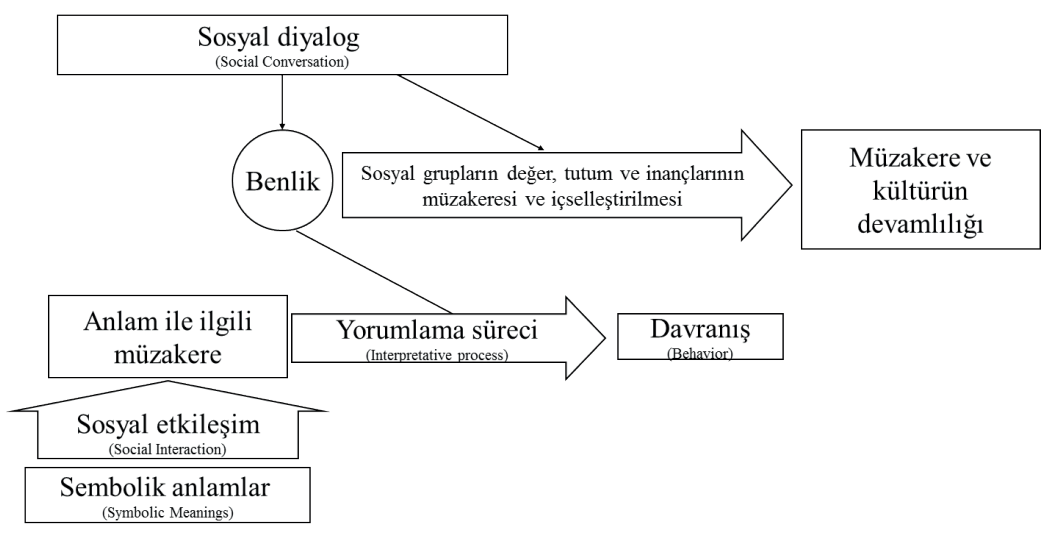

Şekil 13: Sosyal Sembolik Benlik Teorisi (Jackson, 2005) 
Bireylerin davranışlarının sosyal bağlamda açıklandığı diğer bir teori Elliott ve Wattanasuwan'ın (1998) ortaya attığı Sembolik Benlik Tamamlama teorisidir (Symbolic Self Completion). Bu teori bireyin kendisi (self) ile kimliği (identity) arasındaki müzakerenin kavramsallaştırılmasından bahsetmektedir. Literatürde bireylerin kendi kimliklerini maddi (material) ve sembolik (symbolic) kaynakları birleştirerek oluşturduğu iddia edilmektedir ${ }^{11^{*}}$. Mead'e (1934) göre kimlik oluşumu sosyal bir süreçtir ve sosyal diyaloglar ile oluşur. Elliott ve Wattanasuwan (1998) ise maddi ve sembolik olmak üzere iki tür kaynağın bireysel ve sosyal olmak üzere iki tür süreçte rol alarak kimlik oluşumunun gerçekleştiğini savunmaktadır (Şekil 8). Dolayısıyla çalışmamızda sosyal sembolik benlik teorisi davranışın hem bireysel hem de sosyal boyutu olarak ele alınmıştır. Sembolik benlik tamamlama teorisi'sine göre, sosyal ve kültürel olarak kişi, bazı maddi kaynaklara (material resources) ulaşabiliyorsa kendini başarılı olarak algılamaktadır (Wicklund ve Gollwitzer, 1982; Elliott ve Wattanasuwan, 1998). Maddi kaynaklara ulaşan birey kişisel kimliğini bu maddi kaynaklar üzerine kurduğundan davranışın bireysel boyutunda bahsedilmiştir. Diğer taraftan, bireyler belirli maddi kaynakları elde edemediklerinde, bu kaynakların sembolik olarak onlarda olduğunu gösterecek sembolik kaynaklar (symbolic resources) aracılığıyla yaşadığı deneyimler (mediated experinence) temelinde kendi kimliklerini oluşturur. Kişi kendi hayatının sosyal sembollerini kendini tanımlamada kullanır (İş yerinde güçlü bir yönetici olmadığı ancak güçlü olduğunu göstermesi için, bir yöneticinin araba seçiminde ortalamadan büyük, çok çabuk hızlanan, yüksek hacimli silindirli araba tercih etmesi). Bu teorideki kimlik oluşumu bakış açısı, sosyal sembolik diyalog yoluyla kişinin kendini irdelediği, izlediği ve onayladığını varsayar. $\mathrm{Bu}$ durum maddi malların sembolik anlam oluşmasındaki gücü ve bunun kimlik oluşumdaki rolünü açıklamakta olduğu davranışın bireysel düzeyinde bahsedilmiştir. Sembolik anlam tartışması süreci ise sosyal bir süreçtir. Kişi kendini, sadece gördüğü gibi değil aynı zamanda diğer kişilerle girdiği sosyal diyaloglar yoluyla ve diğer kişilerden onay alması temelinde tanımlar. Bu sosyal etkileşimdeki en önemli kısım ise bireyin kimliğinin kaynaklar aracılığı ile oluşmasıdır (Jackson, 2005).

Bem'in (1972) ortaya attığı benlik algısı teorisi (Self-Perception Theory) birey davranışlarını bireysel bakış yanında sosyal çerçevede de açıklayan bir bakış sunmaktadır. Bu yönüyle bu teoride bireyin kendi hareketlerini diğerlerinin hareketlerini yorumladığı gibi yorumlayacağını savunulmaktadır. Yani birey hareketlerini beklenildiği gibi kendisinin özgürce seçtiği doğrultuda değil, sosyal olarak etkilendiği doğrultuda düzenleyecektir (Bem, 1972).

Daha önce bireysel boyutta değerlendirilen bilişsel uyumsuzluk teorisinin (Cognitive Dissonance Theory) (Festinger (1957), kişilerin kendileri konusunda

11 Tüketim psikolojisi ve sosyolojisine göre maddi mallar (material goods) kimlik oluşumunda çok ciddi rol oynamaktadır. 
çelişen tutum ve davranışlarını uyumlaştırma çalışmaları konusu sosyal boyutta da irdelenebilir. Daha önce bahsedilen vida deneyi ve polis hakkındaki tutum deneyinde; birey tutumlarına ters bir hareketi, başkası istediği için yapması (sıkıcı bir iş yaptıktan sonra bu işin sıkıcı olmadığını belirtmeleri, polise karşı olumsuz tutumları varken polisin lehine konuşmaları) nedeniyle tutum ve davranışları arasında farklılık oluşuyordu. Birey kendi tutumlarına aykırı bu davranışı, başkasının isteği ile ve karşılığında hiçbirşey almayarak gerçekleştirdiği (para almayan denek) için tutum-davranış farklılığını ortadan kaldırmak amacıyla tutumlarını değiştiriyordu. Dolayısıyla tutum-davranış değişiminin nedeni dışarıdaki bir etkinin olması bilişsel uyumsuzluk teorisinin sosyal boyutta ele alınmasını sağlamaktadır.

Şekil 4'teki gösterilen Higgins'in (1987) benlik farklılı̆̆ teorisi (self-discrepancy theory), birey davranışını bireysel boyut yanında, sosyal boyuttaki içsel farklılıklar ile de açıklayan bir teoridir. Bu teori, bir bireyin başkasının gözünden gerçekte nasıl olduğu, nasıl olması gerektiği ve idealde nasıl olması gerektiği konusunda da tahminler yürüterek davranışlarını düzenlediğini savunmaktadır.

Sosyal kimlik teorisi (social identity theory), bireylerin kimliklerini bireysel bilişsel rasyonalite ile sosyal ve sembolik yaklaşımlar çerçevesinde diğer kişilerden etkilenerek oluşturduklarını iddia eder. Dolayısıyla oluşan bu sosyal kimlik birey davranışlarını etkileyecektir. Sosyal kimlik bireyin belirli bir sosyal gruba mensubiyeti konusundaki bilgisidir. Bireyin bazı duygular ve değerler bakımından, bir grubun üyesi olmaktan dolayı kendini memnun hissetmesi olarak da sosyal kimlik tanımlanmaktadır (Tajfel ve Turner, 1979). Bu teori, bireyin içinde bulunduğu grubun dayanışmasını arttıracak, gruplar arası rekabeti güçlendirecek davranışların ortaya çıkmasına neden olduğunu iddia etmektedir (Şekil 7). Sosyal kimlik teorisi bu yönüyle birey davranışının bireysel boyutu yanında sosyal boyutunu da değerlendirmektedir.

Douglas’ın (1997) ortaya attığı kültürel teori (Cultural Theory), (Şekil 5) bireyin içinde bulunduğu kültürün, birey davranışlarını belirleyeceği görüşünü savunmaktadır. Birey davranışlarını sosyal boyutta değerlendiren bu teori; belirli kültürlerdeki bireylerin bireylerarası ilişkileri ve sınırlanmalarına göre 4 çeşit kültür tipi ortaya koymaktadır. Bu dört düzeyin keşimi ile birlikte ortaya çıkan kültür türlerinden bireyci (individualist) ve kaderci (fatalist) kültür davranışın bireysel düzeyinde ele alınıp değerlendirilmiştir. Hiyerarşist (hierarchist) ve eşitlikçi (egalitarian) kültür türleri ise davranışın sosyal düzeyinde değerlendirilmesi uygun görülmüştür. $\mathrm{Bu}$ bağlamda hiyerarşist kültür geleneklere bağlılığın çok önemli olduğu, bir aile veya network içindeki tanımlanmış sosyal ilişkilerin bulunduğu, bireylerin bu sosyal yapının dişına çıkmasının zor olduğu ve bu doğrultuda sosyal değişime direncin çok yüksek olduğu bir kültürdür (Douglas, 1997; Offermans, 2010). Bireyler arası ilişkinin serbest olduğu ve bireyler arası uzlaşmanın yüksek olduğu kültür olan eşitlikçi kültür 
ise; bireyleri içinde bulundukları topluluk içinde eşit bir şekilde değerlendiren, bu topluluk içerisinde bireylere basit, görünür ve samimi arkadaşlık kurmalarına olanak tanıyan, ilham verici değerler temelinde oluşmuş bu topluluğun diğer topluluklardan ayrılmasını sağlayan (erdem duvarı ile içerdekileri dışarıdakilerden ayıran) bir kültürdür. Burada eşitlik evrensel değerler ışığında tüm bireylere tanınan eşitlikten çok bir topluluğa mensup olan bireylere tanına bir eşitlik olduğundan dolayı bu tipteki kültürün sosyal boyutta değerlendirilmesi uygun görülmüştür (Douglas, 1997; Thompson, 2018). Dolayısıyla Douglas'ın (1997) ortaya attı̆g bu teoride; bahsi geçen hiyerarşit ve eşitlikçi kültür tipleri, bireyin içinde bulunduğu kültürün, birey davranışlarını belirleyeceği göstermesi açısından davranışın sosyal boyutunda ele alınması gereken teorilerdendir.

Giddens $(1979,1984)$ yapilandırma teorisi ile temsilci (birey nasil hareket eder) ve yapı (sosyal/ kurumsal bağlam) arasında bir model sunmaktadır. Şekil 14'de Jackson (2005) tarafından da gösterildiği gibi, modeldeki sosyal etkileşim (social interaction) bireylerin dil, subjektif yorum, anlam ve bilgiye ulaşımı olarak tanımlanmaktadır. Sosyal etkileşimin doğası ise 3 temel anlayış temelinde açıklanır. Bunlardan ilki süregelen sosyal yaşamın gözlenen özellikleri olarak tanımlanan yansıtma (reflexivity), ikincisi sosyal aktörlerin içinde bulunduğu sosyal uygulamaların tekrar tekrar üretilmesi olarak tanımlanan yinelenme (recursiveness) ve sonuncusu sosyal yaşama giden sosyal süreçteki zaman/mekan farklılığı olarak tanımlanan bölgeselliktir (reginalization). Dolayısıyla bir sosyal etkileşim ne kadar sosyal yaşamın etkilerini yansitıyor, soysal uygulamaların sürekli yinelenmesini sağlıyor ve zaman/mekana göre değişiyorsa o kadar bireysel subjektifliğe (individual subjectivity) etki edecektir. Bireylerin subjektifliği ise bilinç düzeylerini etkileyecektir. Dolayısıyla birey, sosyal etkileşim, sosyal yaşam ve sosyal uygulamaların etkisinde davranacaktır. Giddens pratik/günlük (practical) ve düzensiz (discursive) bilinç temelinde yapılandırma teorisini açıklamaktadır. Pratik bilinç davranışın bireysel kapsamında değerlendirilip açılanmıştır. Düzensiz bilinç (discursive consciousness) ise, aktör kendi hareketlerinin sosyal durumları hakkında fikir beyan edebilir. Sosyal aktörün hareketin farkında olduğunu ve bu farkındalığın belirsiz bir biçimde gerçekleştiğini varsayar. Bireyin hareketi ile ilgili devam eden rasyonel düşünme süreci bu şekil bilinç için gerekli değildir. Bu iki bilinç düzeyi sosyal etkileşimi etkileyecek bu da sosyal kurumların işleyişine yön verecektir (Giddens, 1979; 1984). 


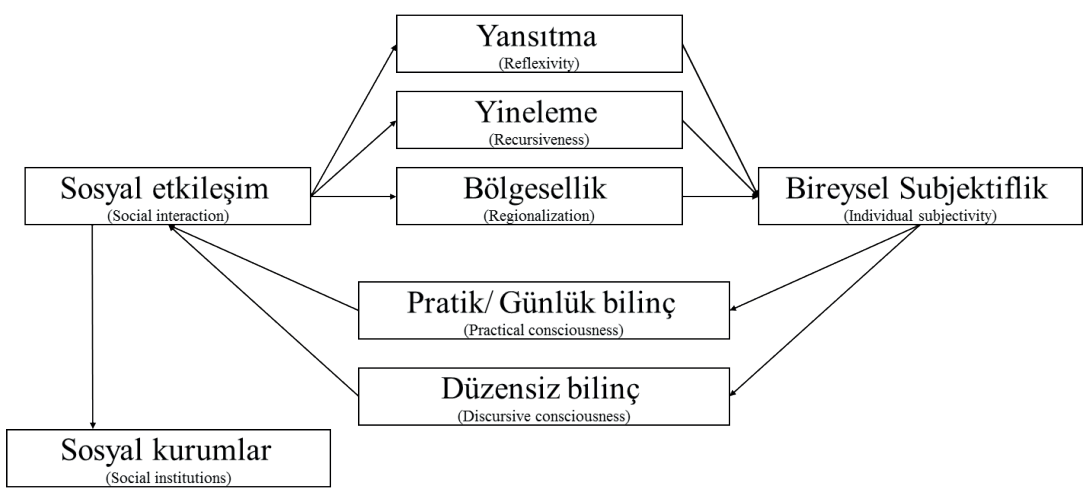

Şekil 14: Yapılandırma Teorisi (Jackson, 2005)

Şekil 9'da görülen Triandis (1977)'in Bireylerarası Davranış Teorisi (Theory of Interpersonal Behavior), birey davranışlarını bireysel unsurların yanında, sosyal kapsamda inceleyen boyutlar içermektedir. Bireylerin niyetlerini belirleyen sosyal faktörler altında roller (roles), normlar (norms) ve bireyin kendisi hakkındaki algisı (self-concept) bulunmaktadır. Triandis'in (1977) modelinde, bireylerin bulundukları sosyal grupların beklentisini karşılayacak sosyal rolleri (social roles) benimseyerek, içinde bulunduğu grup tarafindan oluşmuş normlara uyarak ve kendini grubun ondan beklediği yönde tanımlayacak (self-concept) bir kimlik geliştirerek davranışlarına yön vereceği iddia edilmektedir.

Daha önce içerisinde bireysel unsurların varlığı nedeniyle bahsi geçen Motivasyon Firsat Yetenek Modeli (Ölander ve Thogersen, 1995), bireylerin niyetlerini sosyal normların da belirlediğini iddia etmektedir. Bu çerçevede sosyal bağlamda daha önceden var olan normlara uyum için birey kendi davranışlarını düzenleyecektir. Daha sonra bu niyetler belirli yetenek ve firsatlar ile birlikte davranışa dönüşecektir (Şekil 10). Teori bu yönüyle birey davranışının bireysel boyutu yanında sosyal boyutuyla da ele alınabilir.

Prososyal davranış bireysel boyutta olduğu kadar sosyal boyutta da birey davranışlarını açıklamaya yardımcı olmaktadır. Fabes ve Eisenberg (1998)'in çalışmalarında, bireylerin diğer bireylere karşı olan pozitif davranışlarını; belirli içsel (kişisel normlar, prensipler veya sempati duyulanlar) ve dişsal (diğer insanlardan onay almak vb.) motivasyonlarla yaptıklarını vurgulamaktadır. $\mathrm{Bu}$ açıklamaya göre, başkalarına gösterilen bu pozitif davranışların kaynağ 1 dışsal motivasyon ise, başkalarından onay görmek ise, bu durumda prososyal davranış, davranışın sosyal boyutı olarak ele alınabilir. Örgüt düzeyinde prososyal davranış (prosocial organizational behavior); örgütteki bir üye tarafından, örgütteki rolünü gerçekleştirirken etkileşim içerisinde olduğu birey, grup ve organizasyona karşı ve bu birey, grup veya organizasyonun refahını desteklemek amaçlı sergilenen davranış 
şeklinde tanımlanmaktadır (Brief ve Motowidlo, 1986). Kamusal (public) prososyal davranış; başka bireyler önünde, yardıma ihtiyacı olan birine yardım etmedeki motivasyonu açıklar. Burada yardım eden bireyin amacı; etrafındakilerin onayını veya saygısını kazanarak, değerli biri olarak görülmesini sağlamak ise, bu durumda bu davranışı sosyal boyutta değerlendirmek mümkündür. Özellikle yardım eden bireyin benzer durumdaki yardım vakalarına, bir topluluğun önündeyken veya yalnız başınayken tabi tutulması şeklinde yapılan deneyler, yardım eden bireyin iki ayrı durumdaki davranışlarında farklılıklar olduğunu göstermiştir (Buhrmester, Goldfarb ve Cantrell, 1992). İzlendiğini bilen bireyin davranış1 genellikle olumlu olacaktır. Başkalarının gözü önünde, başkalarına fayda sağlamak için yapılan ve sosyal boyutu olan kamusal prososyal davranış kapsamında bireysel boyutta farklı bir açıdan değerlendirdiğimiz seyirci etkisi (bystander effect) (Myers, 2015) ile, özellikle kalabalık ortamda yardıma ihtiyacı olan birine daha çok yardım edebilecek kişi olduğu varsayımı ile bireyler yardım etme konusunda daha çekingen davranabilir ya da toplum içinde kendini gösterme ya da yardım etmedi dedirttirmemek için yardım etmek isteyebilir. İtaatkar (compliant) prososyal davranış, yardım isteyen birine yardım etmek olarak tanımlanmış ve davranışın bireysel boyutunda incelenmiştir ancak bu davranışın bir de sosyal boyutu bulunmaktadır. Carlo ve Randal (2002), yardım isteme ve buna cevap verme davranışının çocukluk yaşlarında oldukça sık görülen bir davranış olmasına rağmen, ilerleyen yaşlarda itaatkar prososyal davranışın gerçekleşmesi konusunda ayrıntılı araştırmalar yapılmasına ihtiyaç bulunduğundan bahsetmektedir. Ayrıca ileriki yaşlardaki itaatkar prososyal davranışın daha çok onaylanma temelindeki bir tavır (approval-oriented modes) nedeniyle sergilendiği belirtilmektedir. Örgütte de rica edilen yardım isteğini geri çevirmemek yine sosyal ortamın bir sonucudur. Örgütte acil bir durumda ya da kriz anında duruma müdahale ederek sorunun çözümüne katkıda bulunmak ve diğerleri gözünde kişiyi değerli kılmak ve onamak yine prossoyal davranışın sosyal boyutunu göstermektedir. Myers (2015), karşılık beklentisiyle ve koşulsuz yardımseverlik ile sergilenen olmak üzere prososyal davranışı iki şekilde sınıflandırmasından hareketle, prososyal davranış tartış1lırken, burada hatırlanılması gereken bir konu da, bunun sosyal mübadele unsuru olarak da değerlendirilebileciğidir. Bu durum, yardım edenin bir karşıllk beklemesi veya yardımı kabul edenin kendini borçlu hissetmesi gibi bir sonuç doğurabilmektedir.

Prososyal değerlerin birey davranışlarında etkili olduğunu iddia eden ekolojik değerler teorisinin (Jackson, 2005) de bireyin davranışı açısından, sosyal bir yönü bulunmaktadır. Bireyin değer sistemi içerisinde bulunan prososyal (prosocial), ahlaki (moral) ve biyosferik (biospheric) değerlerin, özellikle bireyin davranışlarına yansıyacağı ekolojik değer teorisinin temelini oluşturmaktadır. Bu değer sistemine göre, bireyler diğer bireyleri, gelecek nesilleri veya doğadaki tüm canlıları göz önünde bulundurarak davranışlarını düzenlemektedir. $\mathrm{Bu}$ doğrultuda, bireylerin 
başkalarını, diğer canlıları ve doğayı gözeterek davranmalarının sosyal çevrede kabul görmeyi/sayg1 görmeyi kolaylaştırması gibi sosyal fayda temelinde ele alındığında, ekolojik değerler teorisi kapsamında birey davranışının sosyal yönünden söz etmek mümkündür.

Birey davranışını bireysel fayda-maliyet temelinde değerlendirdiği gibi, sosyal fayda maliyet analizi ile de değerlendiren davranış şekillerinden biri de örgüt düzeyindeki yardım etme davranışıdır. Örgüt düzeyinde yardım etme davranışı, "bireyler arası uyumun teşviki için sergilenen ve iş arkadaşlarının iş ile ilgili sorunları çözmesine yardımcı olacak gönüllü davranışlar olarak tanımlanır" (Podsakoff vd., 2000). Diğer çalışanlar yararına gösterilen bir davranış biçimi olan yardım etme davranışı, bireyler arasındaki ilişkilerin gelişimini sağlayarak organizasyon yararına sergilenen davranışlar kapsamında incelenmektedir (Wolfson, 1981; Van Dyne ve LePine, 1998). Yardım etme davranışının bir diğer sosyal düzeydeki açıklaması da, bireyin kendisi de yardım beklediğinden dolayı yardım etmesidir. Sosyal mübadele teorisi temelinde bahsi geçen karşılıklılık normları (norms of reciprocity) bireyin bir davranışı karşıdakilerden de beklediğinden dolayı göstermesinden bahseder (Thibaut ve Kelley, 1959). Birçok çerçeveden bireyin örgütteki arkadaşlarına kendi isteğiyle yardım etme davranışı sosyal kapsamda değerlendirilecek bir davranıştır.

Daha önce bireysel boyutta ele alınıp değerlendirilen fikrini açıkça söyleme davranışının bir de sosyal boyutu bulunmaktadır. Fikrini açıkça söyleme davranışı değişen çevre koşullarında sürekli gelişimi sağlayıp organizasyon içinde açık bir iletişime olanak tanıyacak bir ortam yaratır (Gorden, 1988; Van Dyne, Cummings ve Parks, 1995). Organizasyon çerçevesindeki bu tip bir davranış; bireyin kendisini sosyal ortamda kabul ettirmek, veya övgü almak amaciyla sergilenebildiği için sosyal boyut temelinde irdelenebilir.

Davranışı sosyal boyutta inceleyen teoriler kapsamında Organ (1990) tarafından ortaya atılan örgütsel vatandaşlık davranışı (organizational citizenship behavior) sosyal boyutta da değerlendirilebilir. Çalışanların birey veya örgüt yararına iş tanımında bulunmayan pozitif davranışlarda bulunması olarak bilinen örgütsel vatandaşlık davranışı, örgütte karşılaşılan güçlükler ve sıkıntılar karşısında şikayet etmeden ve olumlu bir tutum içerisinde çalışmaya istekli olmayı da içinde barındırır. Ayrıca çalışanların düşünceli davranmaları ve kontrollü hareket etmeleri için diğerlerine yardımcı olmayı içermektedir (Allison vd., 2001). Bireyin olumlu tutum içinde olması veya şikayet etmemesinin nedeni; örgütte uyumlu bir birey olarak görünmek istemesi, dolayısıyla örgüt tarafindan kabul görmesi ve dışlanmaması sonucuna ulaşmak istemesi olabilir. Yine örgütsel vatandaşlık davranışının kapsamında, bireyin kendi çıarlarından öte, örgüt çıkarlarını ön planda tutmaları vardır. Sosyal çıkar temelinde açıklayabileceğimiz bu davranış biçimi, bireyin sosyal 
olarak kabul görmesi veya övgü alması nedeniyle sergileniyor olabilir. Diğer taraftan örgütün politik yaşamına katılım göstermeye dönük etkinlikler içeren (Deluga, 1994) bu kapsam (sadece örgütün yararını düşünmek), kimi zaman etik kuralların ihlali veya çevresel duyarlılığın ikinci plana atılmasına rağmen bu davranışları sergilemek, kişisel fayda maliyet analizi ile hem bireysel hem sosyal baskı nedeniyle sosyal boyut içermektedir. Örgütsel vatandaşlık davranışının bir de iş arkadaşlarına işle ilgili yardım etmeyi içeren bir tarafı bulunmaktadır. Ancak örgüt düzeyinde sergilenen bu yardımın, (sosyal mübadele teorisi çerçevesinde açıklanan) ona da yardım edilmesini beklediğinden ötürü sergileniyor olması da muhtemeldir.

Çevreci örgütsel vatandaşlık davranış1 (Boiral, 2009) bireysel boyutta incelendiği kadar, sosyal boyutta da değerlendirilmesi gereken bir davranıştır. Burada çalışanlar, doğal çevrenin yararına davranışlar sergileyerek, kendi çalıştıkları işletme ve o işletmenin üyeleri ile işbirliği içerisinde olma konusunda gönüllü davranırlar. Dolayısıyla çevreci bir işletmede çalışmak, bireyi çevreci davranışa itecektir.

Etik davranış bireysel boyutta değerlendirilebileceği gibi sosyal boyutta da ele alınabilecek bir davranıştır. Bandura'nın ortaya koyduğu sosyal öğrenme teorisinde; bireylerin uygun davranışları önemli olduğunu düşündüğü kişileri modellenmesi sonucu öğrendiğini vurgulamaktadır (Jones, 1989; Luthans ve Kreitner, 1985). Yöneticilerin etik davranış göstermeleri bu yöneticiye bağlı çalışanların da etik davranış göstermelerini sağlayacaktır (Stead, Worrell ve Stead, 1990). Etik davranışın örgüt kültürü haline geldiği bir organizasyonda bireyin etik davranmaması dışlanmasına ve eleştirilmesine neden olabilecektir. Özellikle sosyal normlar bireyin etik davranış göstermesinde etkilidir. Bireylerin bu normları ne zaman ve nasıl uygulayacakları bulundukları ortama bağlı olarak değişir. Dolayısıyla, bireylerin etik davranışı onaylanma, kabul görme veya dışlanmamak için sergilemeleri nedeniyle bu çalışmamızda etik davranışın sosyal boyutu da olduğu şeklinde değerlendirilmiştir.

Bireylerin sadece kendi çıkarları doğrultusunda davranışlarını düzenleyeceklerini savunan rasyonel seçim teorisine karşı geliştirilen teoriler, bireyin davranışlarının bireysel çerçevenin ötesinde değerlendirilmesi gerektiğini savunmaktadır. Birey, içindeki bulunduğu toplumdan dışlanmamak, onay almak veya kabul görmek, sosyal ortamla uyumlu olmak için belirli davranışlar sergilendiğine yönelik bu kısımda anlatılan çalışmalar, davranışın sosyal boyutta incelenmesine olanak tanımıştır. Belirli zamanlarda toplumda oluşmuş sosyal normlara uyum sağlamak veya toplumdan dışlanmamak için ya da daha sonra karşl1ık verileceği düşünülerek sergilenen bu davranışlar, bireyin davranışlarını sosyal ortamın yönlendirilebildiğinin kanıtıdır. $\mathrm{Bu}$ açıklamalardan hareketle, çalışmamızda davranışın soysal boyutu; başkaları tarafindan değer görme, onaylanma, kabul görme, dışlanmama, sosyal ortama uyum sağlama, karşıllk bekleme veya sosyal bir çıkar elde etme için bireyin sosyal 


\section{dïzeyde yaptığı bir fayda maliyet analizi sonucu ortaya çıkan davranışlar olarak tanımlanmıştır.}

\section{Davranışın Normatif Boyutu}

Birey davranışları belirli yer ve zaman için doğru kabul edilen kural, normlar vb. gibi normatif unsurların etkisiyle farklılıklar göstermektedir. Çünkü birey, doğru ve iyiye yönelme konusunda geliştirdiği kişisel norm ve değer yargıları ile benzer tutumdadır ve bu tutumlar bireyin davranışlarını yönlendirmektedir. Dolayısıyla daha önce belirtilen bireysel ve sosyal değerlendirmeler yanında, bireyler davranışlarını normatif bir fayda ve maliyet değerlendirmesi yaparak da düzenlerler. $\mathrm{Bu}$ aslında davranışlara ahlaki çerçeveden yaklaşımı da içine alan bir bakış açısıdır. (Ruepert, vd. 2005). Diğer taraftan normatif boyutta idealizmin de etkisi bulunmaktadır. İdealizimde bireylerin, diğer bireylerin refahına yönelik bir eğilimi söz konusudur (Forsyth, 1992) ve doğru davranış biçiminin her zaman herkes için istenilen sonuçlar getireceğine olan inançları vardır (Kleiser vd., 2003). Ayrıca bu bireyler, diğer bireylere zarar vermekten kaçınır ve tüm paydaşların sonuçlardan tatmin olması gerekliliğini savunur. Aşağıda ele alınan teori, yaklaşım ve modellerde davranışın normatif boyutu bu kapsamda incelenip değerlendirilmiştir.

Bireyin davranışının bireysel ve sosyal ortam boyutları açısında değerlendirirken de söz edildiği gibi, rasyonel seçim teorisi varsayımlarından bir tanesi bireyin kişisel çıkarlarını izler şekilde seçim yaptığı veya davranışlarını düzenlediği varsayımıdır. $\mathrm{Bu}$ varsayım, ekonomik insanın kişisel çıkarlarını, birey davranışlarının ahlaki boyutu ve bireylerin sosyal yapı içerisindeki bu ahlaki boyutları kabulü açısından eleştirilmektedir (Bakınız Tablo 1, rasyonel seçim teorisinin üçüncü varsayımına eleştiri). Yani insan hem davranışlarının ahlaki boyutuna hem de insanların sosyal yapının ahlaki boyutlarını kabulüne odaklanarak davranışlarını düzenler. $\mathrm{Bu}$ iki durum bireyin sadece kendi çıkarlarına göre hareket etmesini engelleyecektir. $\mathrm{Bu}$ bakış açısıyla, birey hareketlerinde davranışın ahlaki boyutunu ele almak mümkündür. Bir diğer rasyonel bakış açısı da, yardım etme davranışının (altruistic behavior) kendini değerli hissetme veya diğerlerinden de aynı şekilde yardım görme amaciyla yapıldığını iddia ederek fayda-maliyet dengesinden bahsetmektedir (Jackson, 2005). Ancak her ne kadar bu girişimler ahlaki kapsamda subjektif beklenen fayda ${ }^{12}$ sınırını genişletse de, rasyonel seçim teorisi tarafından sürekli irdelenir. Uygulamada açıkça tanımlanmış ve ölçülebilen prososyal ve çevreci (pro-environmental) davranışların varlığı, bireylerin kendi çıkarları ötesindeki değerlere sahip olmaları ile ilişkilendirilir ve her ahlaki davranışın rasyonel seçim teorisinin kapsamında olmayacağını gösterir

12 Subjektif beklenen fayda(subjective expected utility), belirli çıktılar konusunda farklı bireylerin farklı inançlara sahip olduğu ve bu çıktıların fayda fonksiyonlarını farklı değerlendirdiklerine yönelik bir yaklaşımdır. 
(Schwartz, 1977; Stern ve Dietz 1994; Schultz, 2001).

Yukarıda da değinildiği gibi, rasyonel seçim teorisi bireysel çıkar bakış açısını yansıttığı gerekçesiyle davranışın ahlakive normatifboyutunu değerlendirmemektedir. Hatta bireylerin bazı ahlaki davranışlarını tamamen bireye hizmet etmesinden dolayı sergilediklerini iddia etmektedir (Jackson, 2005). Örneğin kişi normatif bir davranış olarak değerlendirilen çevreci davranışı (pro-environmental behavior) temiz bir çevrede yaşamakiçin sergilediğinde, dolaylı olarak diğer insanların da temiz birçevrede yaşamasına olanak tanımaktadır, dolayısıyla bazı davranışların bireysel çıkarlar için mi yoksa toplumun uzun vadeli refahı için mi sergilendiği belirlenemeyebilir. Kişi çıkarları için olsa bile, hatta bunun çalışmamızda sosyal boyutu olduğu da kabul edilse, toplumun uzun vadede yararına bir davranış sergilemesi durumunda davranışın bir de normatif veya ahlaki bir boyutunun olduğunu göstermektedir.

Davranışı normatif boyutta inceleyen bir diğer teori Jackson'ın (2005), Schwarz'ın (1973; 1977; 1994) evrensel değerler (universal values) çalışmasını temel alarak geliştirdiği ekolojik değerler (ecological values) teorisidir (Şekil 15). Evrensel değerlerden özellikle prososyal (prosocial), ahlaki (moral) ve biyosferik (biospheric) değerlerin normatif davranışların ortaya çıkmasında etkili olduğu bu teoriler kapsamında irdelenmektedir. Prososyal değerler, tüm düzeydeki tüm insanların refahını gözeten değerlerdir. Ahlaki değerler ise her zaman tüm insanlar için doğru ve iyi olanı yapma konusundaki değerlerdir. Nihayet biyosferik değerler ise tüm canlıları ve doğayı koruma ve gözetme ile ilgili değerlerdir. Bireyin değer sistemi içerisinde bulunan bu üç değerin, bireylerin davranışlarına yansıyacağı ekolojik değer teorisinin temel savını oluşturmaktadır. Bu değer sistemindeki bireylerin diğer bireyleri, gelecek nesilleri veya doğadaki tüm canlıları göz önünde bulundurarak uzun dönemli ve geniş çaplı bir normatif fayda maliyet analizi sonrasında kendi davranışlarını düzenlediği söylenebilir.

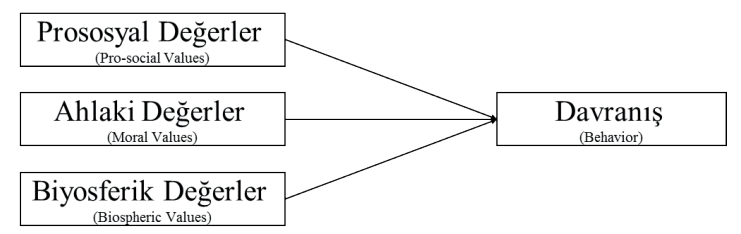

Şekil 15: Ekolojik Değer Teorisi (Jackson, 2005)

Şekil 4'te gösterilen benlik farkl1lığı teorisi (self-discrepancy theory), birey davranışını normatif boyuttaki içsel farklılıklar ile açıklayan bir teoridir. Bu teori bir bireyin gerçekte nasıl olduğu ile idealde nasıl olması gerektiği konusunda tahminler yürüterek davranışlarını düzenlediğini savunmaktadır. Burada ideal bireyin kendine veya başkalarına göre doğru ve iyi olan konusundaki algısını göstermektedir. 
Bazı yazarlar ahlaki ve pro-sosyal davranış boyutlarını ve öncüllerini anlamak için araştırmalar yapmışlardır. Örneğin Schwartz ve Howard (1984) önerdikleri norm aksiyon modelinde; ahlaki davranışların (moral behaviors) belirli yollarla kişisel normların sonuçları şeklinde ortaya çıktığını iddia etmektedir. Kişisel normlar (personal norms) ise bir kişinin hareketleri sonucu elde edecekleri sonuçlar hakkındaki farkındalığı (awareness of concequences) ve bu sonuçlar konusundaki sorumluluğu (ascription of responsibility) ile ortaya çıkar. Modelin ilerleyen kısmında bu kişisel normların davranışa direkt etkisi gösterilmiştir (Şekil 6). Herhangi bir problem/ durumun farkında olan ve bu problem/durumla ilgili kendini sorumlu hisseden bireyler, mevcut konudaki yapması doğru olanlar hakkında normlar geliştirecekler, bu normlar da davranışlarına yansıyacaktır. Davranışın bireysel yönü olan bu teori, çevreci davranış bakış açısıyla değerlendirildiğinde; bireyler kendi davranışlarının sebep olduğu çevre problemlerinin ne kadar çok farkındaysa, kendilerini o kadar çok bu konuda sorumlu hissedecekler ve kendi davranışlarının bu problemleri azaltmak için o kadar çok dikkate değer olduğuna inanacaklardır. Bu durum, kişisel normların ortaya çıkmasını sağlayacak, dolayısıyla çevreci davranış ihtimalini arttıracak ve kişileri harekete geçirecektir (Steg ve De Groot, 2010).

Bireylerin ahlaki ve normatif davranışları (moral and normative conduct) değer-inanç norm teorisi (value belief norm theory) ile açıklanabilir. Norm aksiyon modelinden sonra, Stern vd. (1999) 'sonuçların farkındalığı' boyutunun sabit kişisel değişkenler (değerler ve ekolojik dünya görüşü) tarafından etkilendiğini iddia ederek, norm aksiyon modelini genişletmiş ve değer-inanç- norm teorisini ortaya atmışlardır. Aslında değer-inanç- norm teorisi; değerlerin yeni çevre paradigmasının (new environmental paradigm) bir yansıması olan ekolojik dünya görüşünü güçlendirme yoluyla, sonuçların farkındalığını (awareness of consequences) etkilediğini iddia etmektedir. Burada yeni çevre paradigması; insan ve doğa arasındaki ilişkiyi ve insanın varoluşunun doğanın bir parçası olması fikrini temel alan bir inanıştır. Sonuçların farkındalığı boyutu önceki norm aksiyon modelinde belirtildiği gibi bireylerin kendi isteğiyle sorumluluğu yüklenmesini (ascription of responsibility) etkileyecek bu da kişisel normlara (personal norms) yansıyacaktır. Oluşan bu normlar ise çevreci vatandaşlık davranışı (environmental citizenship behavior) veya isteğe bağlı çevreci davranışı (pro-environmental behavior) belirleyecektir. Stern vd.'nin (1999) değer inanç norm teorisinde asıl odaklandıkları kısım, kişinin değer yargılarına bağlı olarak yeni çevre paradigmasının bireyler tarafından kabulünün değiştiğidir (Dunlap vd., 2000). Yüksek düzeyde özgecil ve biyosferik değerlere sahip olan bireyler; diğer bireyler ile bitki ve hayvanları kendi değerleri çerçevesinde tanımladıklarından, yeni çevre paradigmasını destekleme ihtimalleri çok yüksektir (Schultz, 2001). Stern ve diğerleri (1999) değerinanç-norm teorisini sistematik olarak organizasyonlarda test etmemiştir. Ancak, Scherbaum, Popovich ve Finlinson (2008), değer-inanç-norm teorisini temel alarak iş yerindeki bireylerin enerji tasarrufu davranışlarını araştırmıştır. Bireysel normlar ve 
dünya görüşlerinin enerji tasarrufu davranışına olan etkisinin anlamlı bulunduğu bu çalışmada, yeni çevre paradigmasi ${ }^{13}$ ne kadar güçlü desteklenirse, işyerindeki enerji tasarrufu davranışının o kadar artacağı sonucuna ulaşılmıştır (Şekil 16).

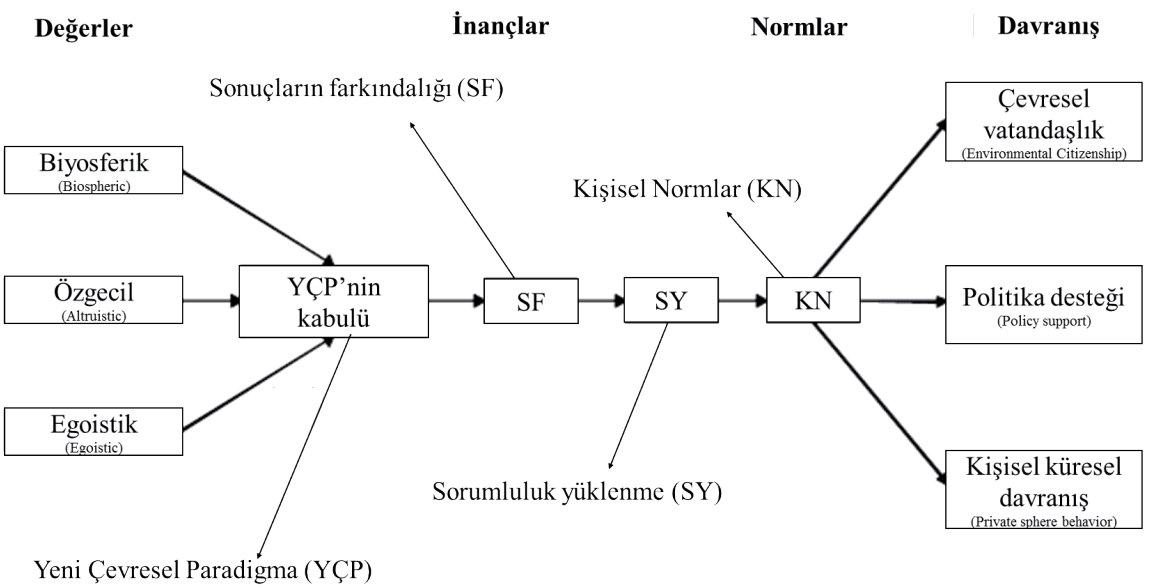

Şekil 16: Değer-inanç norm teorisi (Stern vd., 1999; 2000)

Normatif bakış açısının en genel şekli ve kapsamlısı niyet ve davranışları açıklamaya yardımcı olan çevreci kimlik teorisidir (environmental self-identity). Çevreci kimlik "bireylerin kendilerini çevreye duyarl şekilde hareket eden biri olarak görmeleri" şeklinde tanımlanır (Van der Werff vd., 2013). Güçlü çevreci kimliğe sahip olan bireyler, kendilerini çevreye duyarlı bir birey olarak görür ve gönüllü olarak çevre yararına davranışlar sergiler (Manetti, Pierro ve Livi, 2004).

Boiral ve Paille (2012:431), çevreci örgütsel vatandaşlik davranışını "biçimsel ödüllendirme sistemi tarafindan açık bir şekilde tanımlanmamış ancak organizasyonların daha etkin çevre yönetimine katkı sağlayan bireyin isteğe bağlı davranışları" şeklinde bir tanımlama getirmiştir. Ones ve Dilchert (2012), çalışanların tüm çevreci davranışlarının (pro-environmental behavior) isteğe bağlı olmadığını belirtmiştir. Ancak bunlardan yaklaşık \%70-85'in isteğe bağlı çevreci örgütsel vatandaşlık davranışından kaynaklandığı sonucu oldukça dikkat çekicidir. Bu örnek de bireylerin aslında gelecek nesillere yaşam hakkı sunmak veya çevreyi korumak amacıyla çevreci örgütsel vatandaşlık davranışında bulunduğunu göstermektedir. Sonuç olarak Çevreci ÖVD’nın bireysel ve sosyal boyutta değerlendirilmeği gibi bir de normatif boyutta ele alınması gerekmektedir.

13 'İnsanın dünya üzerindeki diğer tüm yaratıklardan köklü bir biçimde farklı ve diğerleri üzerinde egemen olduğu’ görüşü “İnsanın İstisnalığı Paradigmasının "(Human Exceptionalism Paradigm)” temel düşüncesidir. 1970'lerden itibaren bu paradigma yerini "Yeni Çevre Paradigmasına “(New Ecological Paradigm)” bırakmıştır. Yeni çevre paradigmasının anafikri ise; 'kültür ve teknoloji gibi ayırıcı özellikleri olmakla birlikte, küresel eko sistem içinde insanoğlu, diğer türlerle bağımlılık içindedir ve ekolojik yasalar hiçbir zaman yok farz edilemez' şeklindedir. Bu bağlamda yeni çevresel paradigma bireylerin ekolojik dünya görüşlerini göstermektedir. 
Myers (2015)'in, karşılık beklentisiyle ve koşulsuz yardımseverlik ile sergilenen olmak üzere prososyal davranışı iki şekilde sınıflandırması doğrultusunda, karşılık beklentisi ile sosyal boyutta ele aldığımız prososyal davranışı, koşulsuz yardım etmek ve bundan manevi haz almak açısından bireysel boyutta incelediğimiz gibi, bu teori, yine koşulsuz yardım etme yönüyle normatif boyutta da değerlendirilebilir. Walster ve Piliavin'in (1972) prososyal davranışı, karşılığında herhangi bir maddi veya sosyal ödül beklemeden tamamen gönüllü olarak sergilenen davranış olarak tanımlaması doğrultusunda yine prosoyal davranışın normatif yönünün olduğunu söylemek mümkündür. Carlo ve Randal'ın (2002) orataya koyduğu prososyal davranış tiplerinden özgecil ve gizli olanlar normatif düzeyde ele alınıp değerlendirilebilir. Özgecil prososyal davranış; diğerlerine yardımın kişisel norm ve prensiplerle tutarlı olduğu veya yardım etmeye karşı sempati duyan bireylerin, öncelikli olarak diğerlerinin ihtiyaç ve refahlarını düşünerek sergiledikleri gönüllü yardım etme davranışıdır (Fabes ve Eisenberg, 1998). Özgecil prososyal davranışın ortaya çıkmasındaki iki temel motivasyon sempati (sympathy) ve içsel normlar/ prensiplerdir (internalized norms/ principles). Sempati diğerlerinin duygusal durumlarını algılamak ve anlamak temelinde diğerlerini düşünmek ve onlar için endişelenmek anlamına gelir. Burada asıl düşünülen kişi yardım edilendir (Fabes ve Eisenberg, 1998). Özgecil davranışın ortaya çıkmasındaki diğer bir motivasyon yardım ile ilgili içsel norm ve prensiplerdir. Birçok çalışma içsel norm ve prensiplerin bireyin ahlaki düzeyde bir sorgulaması (moral reasoning) sonucu oluştuğundan bahsetmektedir (Blasi, 1980; Colby ve Kohlberg, 1987; Rest, 1983). $\mathrm{Bu}$ prensipler üst düzeyde içselleştirildiği için (bireyin kendi hakkındaki alg1 ve inançları), yardım konusunda prensip sahibi bireyler, bu davranışı öncelikli olarak yardıma ihtiyacı olan diğer bireyleri düşündükleri için sergileyeceklerdir. Ayrıca üst düzey bir ahlaki sorgulama yapan bireyler, kendi prensiplerine uyum konusunda sorumluluk duydukları için, yüksek ihtimal kendi sorgulamaları ile tutarlı davranışlar sergileyecekler (Kohlberg ve Candee, 1984) ve dişsal motivasyon unsurlarından daha az etkileneceklerdir (Rholes ve Bailey, 1983). Birçok araştırmacı üst düzey ahlaki sorgulamanın (içsel normlar, prensipler ve empati temelinde sorgulama), prososyal davranışın içerisinde var olduğunu göstermektedir (Blasi, 1980; Colby ve Kohlberg, 1987; Eisenberg vd., 1981). Özellikle ahlaki sorgulamalar içermesi özgecil prososyal davranışın normatif boyutta incelenmesine olanak sağlamıştır. Gizli (anonymous) prososyal davranış, yardım edenin kime yardım ettiğini bilmediği, yardım edilenin de ona kimin yardım ettiğini bilmediği yardımdır (Carlo vd., 2003). Bu davranışta taraflar birbirlerini bilmedikleri için, yardım edenin bir karşılık beklemesi veya yardımı kabul edenin kendini borçlu hissetmesi gibi bir durum söz konusu değildir. Bu durumda, gizli prososyal davranışın; herhangi bir maddi, manevi veya sosyal bir ödül beklemeden sergilenen ahlaki ve normatif boyutta incelenebilecek bir davranış olduğu söylenebilir. 
Organizasyonda içerindeki problemleri kabul etmek yerine, her türlü aksi fikir ve güce rağmen bu problemin çözümü konusunda fikrini beyan etmek anlamına gelen, fikrini açıkça söyleme davranışı (Parker vd., 2008) bireysel ve sosyal boyutta analiz edildiği gibi, normatif boyutta da değerlendirilebilecek bir davranıştır. Bu davranış tamamen organizasyonun iyiliği düşünülerek sergilenen bir davranıştır. Dolayısıyla bireyin dışlanma, hatta organizasyondan ayrılmak zorunda kalma gibi risklere rağmen, hala organizasyonun ya da dünya ve toplumun iyiliğini düşünereksergilediği bu davranış normatif boyutta değerlendirilebilecek bir davranıştır. Çünkü birey bu bağlamda bireysel ve sosyal çıkarları aksine olması gereken, doğru olan şeyi yapmakta, idealist bir davranış sergilemektedir.

Etik "ahlaki temelde doğal bir sorgu" (Taylor, 1975:1) olarak tanımlanır ve buradaki ahlaki kelimesi "ahlaki yargllama, ahlaki standartlar ve ahlaki davranış kuralları" (Ferrell ve Skinner, 1988: 103) olarak açıklanır. Trevino, Weaver ve Reynolds (2006) etik davranışı bazı minimum düzeydeki ahlaki standartlara ulaşacak şekilde davranış göstermek, etik dışı davranışı ise dürüst olmamak ve kanunlara uymamak olarak tanımlamıştır. Monin, Pizarro ve Beer (2007) etik olmanın; yanlışın değil doğru olanın arkasından koşmak ve ahlaki olarak doğru olmayan cezbedici birçok şey karşısında kendini sınırlandıracak içsel bir dayanıklılığa sahip olmak olduğunu belirtmektedir. Davranışların ahlaki bir süzgeçten geçirilerek, doğru olanın yapılmasını vurgulayan etik davranışın -önceki kısımlarda içerisine bireysel ve sosyal amaçlar karıştığından dolayı bireysel ve sosyal çerçevelerde incelense de- aslında saf halinin normatif çerçevede incelenmesinin uygun olduğu bir davranıştır.

$\mathrm{Bu}$ kısımda incelenen teorilerden de görüldüğü üzere, bireylerin herkes için en iyi ve en doğru olanın ne olduğu konusundaki normatif düzeyde yaptığı fayda maliyet analizi sonucu davranışlarını düzenlediği söylenebilir. Bu normatif analiz kimi zaman kişinin kendi geliştirdiği bireysel normlar ve değer yargıları temelinde, kimi zaman ise bellirli yer ve zaman için doğru kabul edilen kurallar ve normlar temelinde yapılmaktadır. Burada, bireylerin kendi geliştirdikleri kişisel normları idealizm bakış açısıyla (bireylerin diğer bireylerin refahını da düşünme meyili ve doğru davranış biçiminin her zaman herkes için istenilen sonuçlar getireceği inanc1) değerlendirilp geliştirilmesi söz konusu olabilir. Belirli yer ve zaman için doğru kabul edilen kural ve normlar çerçevesinde hareket ise, davranışın ahlaki çerçevede değerlendirilmesine de olanak sağlamaktadır. Bu kapsam çerçevesinde araştırmamızda davranışın normatif boyutu; bireyin doğru olduğunu düşündü̆ğ̈̈ prensip ve normları doğrultusunda, dünyadaki tüm canlıların iyilik ve refahını düşünerek, ahlaki bir çerçevedeki değerlendirmeleri ve hatta uzun dönemli normatif düzeydeki fayda maliyet analizleri sonucu sergilediği gönüllü, idealist davranışlar olarak tanımlanmıştır. 
Tablo 2 .

Davranış Teorileri Taksonomisi

\begin{tabular}{|c|c|c|}
\hline Bireysel & Sosyal & Normatif \\
\hline $\begin{array}{l}\text { Basit Beklenti Değer Tutum Teorisi } \\
\text { (Fishbein, 1973) }\end{array}$ & $\begin{array}{l}\text { Nedenli Eylem Teo (Ajzen ve Fishbein, } \\
\text { 1980) }\end{array}$ & $\begin{array}{l}\text { Ekolojik Değerler Teorisi (Jackson, } \\
\text { 2005) }\end{array}$ \\
\hline $\begin{array}{l}\text { Nedenli Eylem Teorisi (Ajzen ve } \\
\text { Fishbein, 1980) }\end{array}$ & Planlanmış Davranış Teo (Ajzen 1991) & $\begin{array}{l}\text { Benlik Farklılığı Teorisi (Higgins, } \\
\text { 1987) }\end{array}$ \\
\hline $\begin{array}{l}\text { Planlanmış Davranış Teorisi (Ajzen } \\
\text { 1991) }\end{array}$ & $\begin{array}{l}\text { Normatif Davranışa Odak Teo(Cialdini } \\
\text { vd. 1990; 1992) }\end{array}$ & $\begin{array}{l}\text { Norm Aksiyon Modeli(Schwarz 1977, } \\
\text { 1992) }\end{array}$ \\
\hline Benlik Alg1s1 Teorisi (Bem, 1972) & Sosyal Sembolik Benlik (Mead, 1934) & $\begin{array}{l}\text { Değer İnanç Norm Teorisi (Stern vd., } \\
\text { 1990; Stern 2000) }\end{array}$ \\
\hline $\begin{array}{l}\text { Bilişsel Uyumsuzluk Teorisi (Festinger, } \\
\text { 1957) }\end{array}$ & $\begin{array}{l}\text { Sembolik Benlik Tamamlama } \\
\text { (Wicklund ve Gollwitzer, 1982; Elliott } \\
\text { ve Wattanasuwan, } 1998\end{array}$ & $\begin{array}{l}\text { Çevreci Kimlik Teorisi (Van der Werff } \\
\text { vd., 2013) }\end{array}$ \\
\hline $\begin{array}{l}\text { Benlik Farklılığı Teorisi (Higgins, } \\
\text { 1987) }\end{array}$ & Benlik Algısı Teorisi (Bem, 1972) & $\begin{array}{l}\text { Çevreci Örg. Vatandaşlık Davranışı } \\
\text { (Boiral) }\end{array}$ \\
\hline $\begin{array}{l}\text { Kültürel Teori (Thompson vd., 1990; } \\
\text { Douglas, 1997) }\end{array}$ & $\begin{array}{l}\text { Bilişsel Uyumsuzluk Teorisi (Festinger, } \\
\text { 1957) }\end{array}$ & $\begin{array}{l}\text { Prososyal Davranış (Berkowitz, 1972; } \\
\text { Krebs, 1982; Eisenberg vd., 1981) }\end{array}$ \\
\hline \multicolumn{3}{|l|}{$\begin{array}{l}\text { Değer İnanç Norm Teorisi (Stern vd., } \\
\text { 1990; Stern 2000) }\end{array}$} \\
\hline - Egoistic değerler & $\begin{array}{l}\text { Benlik Farklılığ Teorisi (Higgins, } \\
\text { 1987) }\end{array}$ & $\begin{array}{l}\text { Fikrini Açıça Söyleme Davranışı } \\
\text { (Hirschman, 1970) }\end{array}$ \\
\hline $\begin{array}{l}\text { Ekolojik Değerler Teorisi (Jackson, } \\
\text { 2005) }\end{array}$ & $\begin{array}{l}\text { Sosyal Kimlik Teorisi (Tajfel ve } \\
\text { Turner, 1979) }\end{array}$ & $\begin{array}{l}\text { Etik davranış (Taylor, 1975; Ferrel ve } \\
\text { Skinner, 1988) }\end{array}$ \\
\hline $\begin{array}{l}\text { NormAksiyon Modeli (Steg ve De } \\
\text { Groot }(2010)\end{array}$ & $\begin{array}{l}\text { Kültürel Teori (Thompson vd., 1990; } \\
\text { Douglas, 1997) }\end{array}$ & \\
\hline $\begin{array}{l}\text { Sosyal Kimlik Teorisi (Tajfel ve } \\
\text { Turner,1979) }\end{array}$ & $\begin{array}{l}\text { Yapılandırma Teorisi (Giddens, } \\
\text { 1979;1984) }\end{array}$ & \\
\hline $\begin{array}{l}\text { Çevreci Kimlik Teorisi (Van der Werff } \\
\text { vd., 2013) }\end{array}$ & $\begin{array}{l}\text { Bireylerarası Davranış Teorisi } \\
\text { (Triandis, 1977) }\end{array}$ & \\
\hline $\begin{array}{l}\text { Sembolik Benlik Tamamlama } \\
\text { (Wicklund ve Gollwitzer, 1982; Elliott } \\
\text { ve Wattanasuwan, } 1998\end{array}$ & $\begin{array}{l}\text { Motivasyon Firsat Yetenek Modeli } \\
\text { (Ölander ve Thogersen 1995) }\end{array}$ & \\
\hline $\begin{array}{l}\text { Bireylerarası Davranış Teorisi } \\
\text { (Triandis, 1977) }\end{array}$ & $\begin{array}{l}\text { Prososyal Davranış (Berkowitz, 1972; } \\
\text { Krebs, 1982; Eisenberg vd., 1981) }\end{array}$ & \\
\hline $\begin{array}{l}\text { Motivasyon Firsat Yetenek Modeli } \\
\text { (Ölander ve Thogersen 1995) }\end{array}$ & $\begin{array}{l}\text { Ekolojik Değerler Teorisi (Jackson, } \\
\text { 2005) }\end{array}$ & \\
\hline $\begin{array}{l}\text { Bilişsel Çaba - Kontrol, Otomatikleşme } \\
\text { ve Sezgisel Yaklaşım (Jager, 2003) }\end{array}$ & $\begin{array}{l}\text { Yardım Etme Davranışı (Podsakoff, } \\
\text { vd., 2000) }\end{array}$ & \\
\hline $\begin{array}{l}\text { Çerçeveleme, Önceliklendirme ve } \\
\text { Yanlılık Yaklaşımı (Tversky ve } \\
\text { Kahneman, 1974) }\end{array}$ & $\begin{array}{l}\text { Fikrini Açıça Söyleme Davranışı } \\
\text { (Hirschman, 1970) }\end{array}$ & \\
\hline $\begin{array}{l}\text { Yapilandırma Teorisi (Giddens, } \\
\text { 1979;1984), }\end{array}$ & $\begin{array}{l}\text { Örg. Vatandaşlık Davranışı (Organ, } \\
\text { 1990) }\end{array}$ & \\
\hline $\begin{array}{l}\text { Prososyal Davranıș (Berkowitz, 1972; } \\
\text { Krebs, 1982; Eisenberg vd., 1981) }\end{array}$ & $\begin{array}{l}\text { Çevreci Örg. Vatandaşlık Davranışı } \\
\text { (Boiral, 2009) }\end{array}$ & \\
\hline $\begin{array}{l}\text { Yardım Etme Davranışı (Podsakoff } \\
\text { vd., 2000) }\end{array}$ & $\begin{array}{l}\text { Etik Davranış (Taylor, 1975; Ferrel ve } \\
\text { Skinner, 1988) }\end{array}$ & \\
\hline \multicolumn{3}{|l|}{$\begin{array}{l}\text { Fikrini Açıça Söyleme Davranışı } \\
\text { (Hirschman, 1970) }\end{array}$} \\
\hline \multicolumn{3}{|l|}{ Örg. Vatandaşlık Davranışı } \\
\hline \multicolumn{3}{|l|}{$\begin{array}{l}\text { Çevreci Örg. Vatandaşlık Davranışı } \\
\text { (Boiral, 2009) }\end{array}$} \\
\hline $\begin{array}{l}\text { Etik Davranış (Taylor, 1975; Ferrel ve } \\
\text { Skinner, 1988) }\end{array}$ & & \\
\hline
\end{tabular}


Özetle, araştırmamızın ikinci aşamasında incelenen 26 davranış teori, yaklaşım ve modeli sonucunda, bireyin kendi maddi ve manevi çıkarları, duyguları, alışkanlıkları ve kişisel norm ve değer yargıları doğrultusunda bireysel, toplumun beklentilerine uyum sağlama, onaylanma, kabul görme ve sosyal normlara uyma konusunda sosyal bağlamda davranışlarını düzenlendiği, diğer taraftan doğru ve iyiye yönelme konusundaki kişisel norm/değer yargıları ve tutumu ile davranışlarını normatif ve ahlaki bir süzgeçten geçirerek düzenlediği ve idealistçe davrandığı söylenebilir. Bu aslında davranışlara ahlaki çerçeveden yaklaşımı da içine alan bir bakış açısıdır. $\mathrm{Bu}$ doğrultuda normatif davranışın, bireyin kendi isteği ile karşılık beklemeden idealist bir bakış açısıyla diğer birey, canlılar ve doğayı düşünerek ortaya çıktığı ifade edilebilir.

\section{Bireysel, Sosyal ve Normatif Davranış (BSN Davranış) Modeli Önerisi}

Yukarıdaaçıklananteoriveyaklaşımlarfarklıkapsam/bağlamlarda, belirliyönleriyle birbiriyle örtüşen, belirli yönleriyle birbirinden ayrılan modeller sunmuşlardır. Farklı zamanlarda farklı kişilerin görüşlerini yansıtan bu teori, yaklaşım ve modelleri ortak bir çatı/yapı etrafında toplamak ve bir modele ulaşmak mümkün mü düşüncesiyle yola çıktığımız bu çalışmamızda, araştırmalarımız bize bunun mümkün olabileceğini göstermiştir. Üç aşamalı gerçekleğitirdiğimiz çalışmamızın birinci aşamasında; 12 temel davranış teori ve yaklaşımının analizi sonucunda birey davranışları bireysel, sosyal ve normatif açıdan gruplanabileği kanaatine varılmıştır. İkinci aşamasında, literatürde kabul görmüş 26 davranış teori, yaklaşım ve modeli incelenerek, birey davranışları üç majör kategoride bireysel, sosyal ve normatif açıdan gruplandırılmış ve bu üç boyutun tanımları yapılmıştır. Çalışmamızın üçüncü aşamasında da teorik çalışmalar ve modeller ışı̆̆ıında bu üç birey davranışını açıklayan kavramsal bir model ortaya konulmuştur (Şekil 17).

Literatürdeki bazı teori ve yaklaşımlar davranışı birey odak noktası ile, bireysel fayda maliyet analizi sonucu gerçekleşen bir hareket olarak tanımlamışlardır. Rasyonel seçim teorisinin (Elster, 1986; Homans 1961) öncülüğünü yaptığı bu bakış, bireyin tamamen kendi kişisel çıkarları doğrultusunda davranışlarını düzenlediğini iddia etmektedir. Yani burada birey maddi (ödül, ceza, terfi vb.) veya manevi (kendi mutlu, iyi, değerli hissettiren) çıkarının maksimum olduğu noktaya ulaşmak için çaba sarfetmektedir. Ancak bireyin sinırlı rasyonel olduğu, her zaman fayda maliyet analizi yapabilecek kadar basit durumlarla karşılaşmadığ 1 da bir gerçektir. Bu durumlarda birey yine kendi çıkarları odak noktasında sezgileri veya duygularıyla hareket etmektedir. Diğer taraftan, birey fayda maliyet analizi yapmaya gerek duymayacak kadar alışıldık bir durumla da karşılaşabilir. Bu tip durumlarda ise, bireyler önceden öğrendikleri, alışanlık veya rutin haline getirdikleri davranışlar herneyse o şekilde davranmaktadır. Davranışı birey odak noktasıyla inceleyen bu 
bakış açısı, davranışın bireysel düzeyde incelenmesine olanak tanımaktadır. $\mathrm{Bu}$ noktadan hareketle çalışmamızda analiz edilen 26 teoriden 24'ü (Tablo 2) davranışın bireysel boyutta ele alınabileceğini ve tanımlanabileceğini bize göstermiştir. $\mathrm{Bu}$ doğrultuda davranışın bireysel boyutu tarafımızdan 'bireyin maddi veya manevi çıar elde etmek için kimi zaman bireysel düzeyde fayda maliyet analizi sonucu sergilediği, kimi zaman haz aldı̆̆ı, yapmaktan mutlu olduğu veya rahatsızlı ve huzursuzluk duymamak için ya da kendini iyi ve değerli hissettiği için yaptı̆̆l, kimi zaman ise önceden öğrendiği hatta alışkanlık veya rutin haline getirdiği davranışlar' olarak tanımlanmıştır. Bu tanıma göre, birey maddi/manevi çıkarları doğrultusunda veya kendini görmek istediği şekilde, kendini mutlu, iyi hissetmek veya huzursuzluk duymamak için, bazen önceden öğrenerek alışkanlık ya da rutin haline getirdiği, bazen de duygularıyla hareket ettiği için o şekilde davranmaktadır. Tanımdan hareketle, davranışın bireysel boyutu "bireysel fayda-maliyet (bireysel çıkar)", “duygusal tamin" ve "alışkanlık/ rutin" olmak üzere üç alt boyuttan oluştuğu ortaya konulmuştur.

Davranışın bireysel düzeyde ele alındığı şekliyle birey, her zaman kendi maddi ya da manevi çıkarları ya da alışkanlıkları veya duyguları doğrultusunda hareket etmemektedir. Özelikle bireyin bulunduğu sosyal ortam/ bağlam bireyin davranışlarını düzenlemesinde etkili olmaktadır. Bu kapsamda çalışmamızda analiz edilen 26 teoriden 21'i (Tablo 2) davranışın sosyal boyutu ile açıklanabileceğini göstermiştir. $\mathrm{Bu}$ incelemeler sonucunda, davranışın sosyal boyutu tarafimızdan 'başkaları tarafindan değer görme, onaylanma, kabul görme, dışlanmama, sosyal ortama uyum săglama, karşılık bekleme veya sosyal bir çıkar elde etme için bireyin sosyal düzeyde yaptığı bir fayda maliyet analizi sonucu ortaya çıkan davranışlar' olarak tanımlanmıştır. Bu tanıma göre birey, davranışlarını içerisinde bulunduğu sosyal ortama uyum sağlamak veya oluşmuş sosyal normlara uymak, diğer bireyler tarafından kabul görmek veya dışlanmamak için kendi davranışlarını sosyal bir fayda maliyet analizine tabi tutarak düzenlemektedir. Ya da davranışları sonucunda karşı taraftan bir karşılık veya sosyal bir çıkar beklemektedir. Bu açıklama 1şığında çalışmamızda davranışın sosyal boyutu; "sosyal fayda-maliyet (sosyal çıar)", "karşılık bekleme", "kabul görme" ve "uyum sağlama" olmak üzere dört alt boyuttan oluşmaktadır.

Son olarak, bu çalışma kapsamında davranışın bireysel ve sosyal boyutları ile birlikte normatif boyutu da teoriler bazında incelenmiştir. 26 teoriden 9 davranış teorisinin (Tablo 2) normatif kapsam dahilinde incelenebileceğinden hareketle, davranışın normatif boyutu tarafımızdan 'bireyin doğru olduğunu düşündüğ̈̈ prensip ve normları doğrultusunda, dünyadaki tüm canlıların iyilik ve refahını düşünerek, ahlaki bir çerçevedeki değerlendirmeleri ve hatta uzun dönemli normatif düzeydeki fayda maliyet analizleri sonucu sergilediği gönüllü, idealist davranışlar' olarak 
tanımlanmıştır. $\mathrm{Bu}$ davranışlar, bireyin uzun dönemli normatif bir fayda-maliyet analizi ile, doğru ve ahlaki olanın ne olduğu sorgusu sonrası geliştirilmiş, idealist, kişisel prensip ve normlar ışığında, tüm canlıların refahı ve iyiliğini düşünerek sergilediği gönüllü davranışlardır. Normatif davranış tanımından da görüleceği üzere davranışın normatif boyutu "normatif fayda-maliyet/ uzun dönemli çıkar", "tüm canlıların refahı", "karşılıksız yardım”, "gönüllı̈ davranış” ve "idealism” olmak üzere beş alt boyuttan oluşmaktadır.

Davranış teori, yaklaşım ve modellerinin bireysel, sosyal ve normatif boyutlar temelinde ayrıştırılmasından sonra, çalışmamızın üçüncü aşamamızda; literatürdeki ilgili teoriler bünyesinde geliştirilmiş modeller de dikkate alınarak söz konusu bireysel, sosyal ve normatif boyutta ele aldığımız birey davranışların nedenlerinin açıklanması arayışı, çalışmamızın nihayetinde bir kavramsal model önerisine dönüştürülmesini sağlamıştır. Davranışın tanımında da nedenli, güdümlü ve amaca yönelik olduğu belirtilmektedir (Kolasa, 1979). Önerdiğimiz bu modelde tutumların davranışlara yansıdığını gösteren örgütsel davranış literatüründeki birçok çalışmanın (Ajzen ve Fishbein, 1980; Triandis,1977; Ölander ve Thogersen 1995; Ajzen 1991) sonucuna göre kabul görmüş bir nedensellik bulunmaktadır. Bu nedensellikte, bireyin tutumlarının amaçlar tarafından nasıl aracı edildiği ve durum ile koşullar tarafından nasıl düzenlendiği gösterilmiştir (Stern vd., 2000; Ölander ve Thogersen 1995; McShane ve Von Glinow, 2016). Buna göre birey her zaman kendi tutumları doğrultusunda hareket etmemekte, özellikle ulaşmak istediği amaçlar tutumun davranışa dönüşümünde etkili olmaktadır (Triandis,1977; Ölander ve Thogersen 1995; Ajzen 1991). Diğer taraftan bulunulan durum ve koşullar da bireyin her zaman tutumları doğrultusunda davranışlarını düzenlemelerine izin vermemektedir (Stern vd., 2000). Yine de bireyin tutum ve davranışları arasında bir uyum sağlama isteği daha önce Benlik algısı teorisinde (Festinger, 1957) de açıklanmıştır.

Örgütsel davranış çalışmalarının birçoğu, birey davranışlarının bireylerin sahip olduğu değer yargıları ile yakından ilgili olduğunu idda etmektedir (Lancaster, 1966; Ajzen, 2005; Rokeach 1973; Schwartz, 1977; Swartz, 1994). Bireyin kendi değerleri çerçevesinde davranması ise, her koşul ve durumda meydana gelen bir durum olmamaktadır. Bazen birey belirli amaçlara ulaşmak için (Gutman, 1982; Reynolds ve Gutman 1988) kendi değerlerinden çok aksi bir yönde davranabildiği gibi, bazı durumlarda kendi değerlerine uyumlu, bazı durum ve koşullarda ise kendi değerleriyle çelişen davranışlar gösterebilmektedir (Schwartz, 1973; 1977). Diğer taraftan, Lindenberg ve Steg'in (2007) ortaya koyduğu amaç çerçeveleme teorisinde; bireylerin sahip olduğu değerlerin yanında, ulaşmak istedikleri amaçların da davranışı belirlediğini iddia edilmiştir. Hiç şüphesiz ki bireyleri bu amaçlara ulaşmak konusunda davranmaya iten belirli motivasyonları söz konusudur (Tabernero ve Hernández, 2011; McShane ve Von Glinow, 2016). Amaç çerçeveleme teorisi 
bireylerin amaçlarının haz (hedonic), kazanç (gain) ve normatif (normative) temelde farklılıaştığından bahsetmektedir (Lindenberg ve Steg, 2007). Örneğin Lindenberg (2001) çevreye duyarlı davranışın bazı bireylerde gereklilik ve zorunluluklara uymak amacıyla, bazılarında ise çevreye yararlı bir davranış sergilenmesinin verdiği hazı hissetmek amacıyla sergilendiği, dolayısıyla bireyden bireye amaçlara ulaşmadaki motivasyonun değiştiğine değinmektedir. Bu çerçevede bazı amaçların dişsal, bazı amaçların ise içsel motivasyon unsurlarıyla desteklendiği söylenebilir.

Çalışmamızın bütün aşamalarında literatürün bize sağladığı bu tespit, çalışmamızın araştırma modelini resmetmekte olup, modelin ortaya çıkışını özetlemektedir. Özetle, araştırmamızın üçüncü ve son aşamasında, araştırmanın birinci ve ikinci aşamalarının sonucunda ortaya koyduğumuz bireyin bireysel, sosyal ve normatif boyuttaki 3 davranışını açıklayan BSN Davranış Modeli (Bireysel, Sosyal ve Normatif Davranış Modeli) önerilmektedir (Şekil 17).

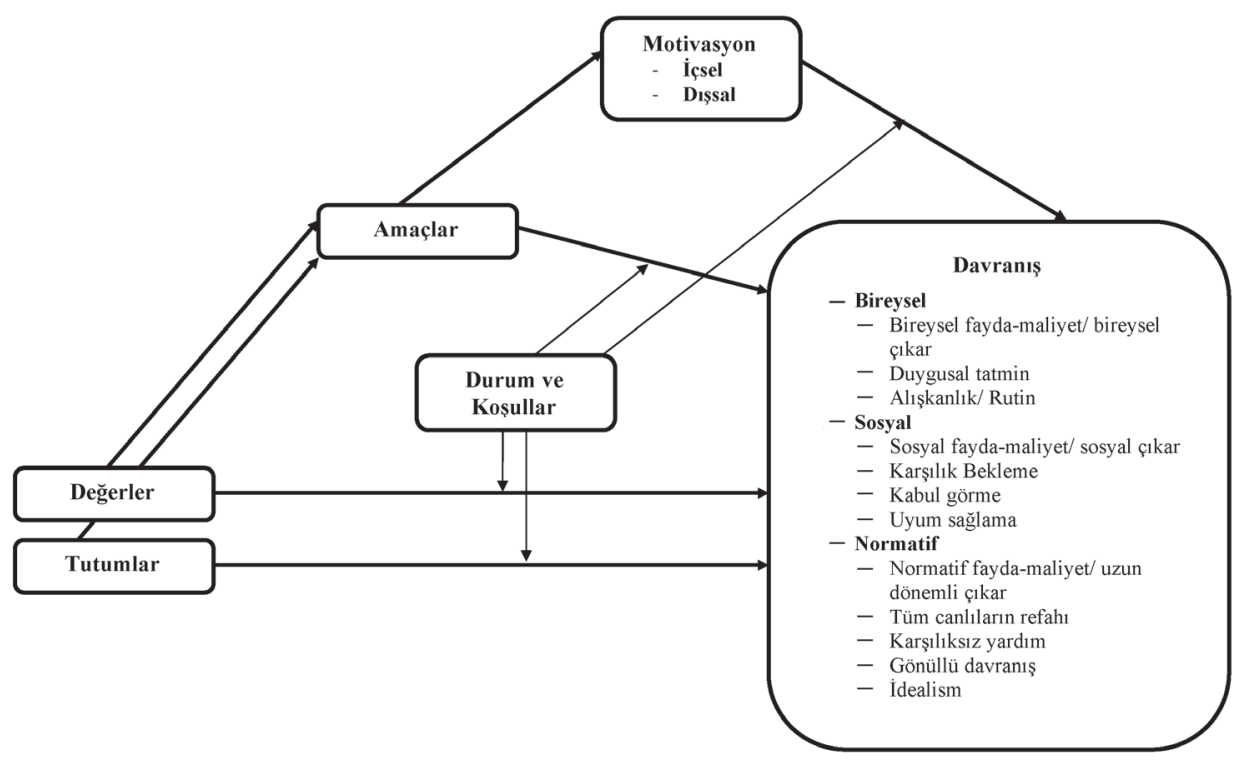

Şekil 17: BSN DAVRANIŞ MODELİ (Bireysel, Sosyal ve Normatif Davranış Modeli)

\section{Sonuç}

Birey davranışlarının irdelenmesi ve açıklanmaya çalışılması milattan önceki yıllara dayanacak kadar eskidir. MÖ 300'lü yıllarda yaşadığı bilinen Aristo ve Platon gibi filazofların birey ve toplum davranışlarını açıklamaya yönelik düşünceleri günümüze kadar ulaşmıştır. Her ne kadar Aristo'nun mantık çerçevesinde nesnelerin nedenselliği ile ilgili fikirleri bir temel teşkil etse de, psikoloji alanının bir bilim olarak kabul edilmesi, davranışla ilgili çalışmaların daha sistematik olarak değerlendirilmesine ve pozitif bilimler çerçevesinde incelenmesine olanak tanımıştır. Psikoloji ve sosyoloji 
bilminin örgüt çerçevesinde değerlendirilmesi ise, bireyin çalıştığ örgüt içinde hem bireysel hem de topluluk olarak davranışlarının incelenmesine olanak tanımıştır.

Örgütsel davranış displini bireyin kendisi, gruplar ve yapı olmak üzere birey davranışlarını etkileyen üç öğe temelinde gelişmiştir (Robbins ve Judge, 2013). Burada amaç bu öğelerin bireylerin davranışlarına yansıması ile birlikte, örgütün etkinlik ve verimliliğinin nasıl değiştiğinin tespitidir. $\mathrm{Bu}$ ana amaç çerçevesinde; psikoloji, sosyoloji ve sosyal psikoloji alanında geliştirilmiş birçok teori, örgüt düzeyindeki bireylerin davranışlarını açıklamada kullanılmıştır, hatta bu düzeyde yeni davranış teorileri de geliştirilmiştir. Bu teoriler altı görmeyen adamın fili tasviri metaforunda ${ }^{14}$ olduğu gibi, her bir araştırmacının birey davranışlarının belirli bir bölümünü alıp incelediği çalışmalardır.

Ayrı ayrı kapsam ve bağlamlarda ortaya atılmış görüşler doğrultusunda, literatürde kabul görmüş 26 davranış teori, yaklaşım ve modelleri tek bir çatı/yapı altında toplamaya ve model oluşturmaya yönelik 3 aşamalı araştırmamızın ilk iki aşaması kapsamında bu görüş, teori, yaklaşım ve modellerin ayrıntılı olarak incelenmesi sonucunda birey davranışlarını ele alış şekline göre davranışların belirli çerçevelerde gruplandırılabileceği tespit edilmiştir. Bu gruplandırma; bireyin bireysel, sosyal ve normatif düzeydeki davranışları şeklindedir. Bireyin bireysel boyutta ele alınan davranışları; bireysel düzeyde bir fayda maliyet analizi sonucu ortaya çıkan, bireyin kendi çıkarını düşünerek, maddi ve manevi kazanç sağlayacağı düşüncesiyle ya da duyguları doğrultusunda sergilediği davranışlar veya alışkanlıklardır. Buradaki kazanç ile elle tutulur bir getiri, duygusal bir tatmin veya haz hissedilmesi kastedilmektedir. Bireyin sosyal boyutta ele alınan davranışları; sosyal bir topluluk içerisinde o topluluk tarafından kabul görmek için sergilenen, o topluluğun bir üyesi olmanın getirdiği kurallara veya normlara uymak amacıyla, sosyal düzeydeki bir fayda-maliyet analizi sonucu ya da karşılık bekleyerek sergilediği davranışlarıdır. Bireyin normatif boyuttaki davranışları ise, normatif bir fayda maliyet analizi ile tüm canlıların refahını düşünerek, neyin en doğru davranış olduğu sorgulaması ile, karşılık beklemeden sergilediği idealist bir tarafı bulunan davranışlarıdır.

Çalışmamızın birinci aşamasında bireyin davranışlarının bireysel, sosyal ve normatif boyutta gruplandırılabileceği kaanatinden sonra ikinci aşamasında literatürde ele alınan 26 davranış teori, yaklaşım ve modelleri bu üç ayrı boyutta değerlendirildiğinde, bu teorilerilerin daha çok bireysel ve sosyal boyutta birey davranışlarını açıkladığı gözlenmiştir İncelenen 26 davranış teori, yaklaşım ve

14 Altı görmeyen adamın fili tasviri metaforu: Altı görmeyen adam filin farklı bir tarafına getirilir ve kendi taraflarındaki dokundukları alanlara göre fili tarif etmeleri istenir. Hepsi oldukları yerin özelliklerine göre fili tarif etmelerine rağmen, yerel olarak doğru olsada filin bütününü hiçbiri tasvir edememektedir. Bu bütüncül bakış açısını (holism) açıklamak amaçlı kullanılan bir metafordur. Burada birey daranışlarının açıklamasında her bir teorinin davranışın bir kısmını açıklayabileceği ancak bütünü açıklamakta eksik kalacağına atıf bulunmaktadır. 
modelinden 24'ünün bireysel boyutu, 20'sinin sosyal boyutu ve 9'unun normatif boyutu ele almış oldukları tespit edilmiştir. Bu durum, araştırmacıların bireylerin daha çok kendi çıkarlarını göz önünde bulundurarak veya sosyal açıdan bulunulan ortamın değerlendirmesi sonucu davranışlarını düzenlediklerini ortaya koyma çabasını göstermektedir. Diğer taraftan birey davranışını normatif boyutta ele alan teorilerin azınlıkta olmasının bir nedeni, ilgili davranış teorilerinin örgüt çerçevesinde incelenmesi olabilir. Sosyolojik düzlemde (sosyal hayatta) bir davranış normatif kapsamda ele alınabiliyorken, örgüt düzleminde aynı davranışın (örgütte çalışmaya devam etmek, çıkarlarını dikkate almak, kendini göstermek, öne çıkmak uyum sağlamak, kabul görmek ve uyum sağlamak gibi) bireysel veya sosyal formdaki davranışlara dönüşebileceği öngörülmektedir.

Davranışının sosyal boyutu da olsa normatif boyutu da olsa aslında insan kendini düşünen bir varlıktır. Ya maddi ve manevi çıkarları, duyguları, alışkanlıkları ile hareket eden ya da başkalarına kendini kanıtlamak, dışlanmamak, onay görmek, uyum içinde yaşayamak ya da bir gün davranışının karşılığını görmek için hareket ediyor ya da uzun vadede temiz bir dünyada yaşamak, nesline ve canlılara ve doğaya zarar vermemek ve toplumun uzun vadede yararı için davranıyor olabilir, davranışlarının ahlaki ve idealist bir yönü de bulunabilir. Bireyin bu bireysel, sosyal ve normatif düzeydeki davranışlarının ortaya çıkmasında; kimi zaman bireyin tavır ve tutumları kimi zaman ise geçmişten beri var olan değer yargıları etkili olabilmektedir. Ancak bazı değer ve tutumlar her durum ve koşulda davranışa yansımayabilir. Bu bağlamda, kişilerin ulaşmak istedikleri amaçları ve bu amaca ulaşmak için onları motive eden unsurlar yine davranışı belirlemede oldukça önemlidir. Birey davranışlarını açıklamada değerler, amaçlar, tutum, durum ve koşullar ile motivasyon öğeleri farklı roller üstlense de, bu öğelerin birbirini etkileyecek şekilde davranışı açıkladığı bu çalışmada ulaşılan sonuçlardandır. Bu çerçevede bireyin niçin bu şekilde davrandığını, davranışlarının bireysel, sosyal ve normatif boyutunu açıklamak üzere bu çalışmada bir model önerilmiştir.

Davranışın yapısını açıklamak ve bir model geliştirmek arayışı ile tasarlanan bu çalışmada, taranan literatür ve değerlendirilen davranış teori, yaklaşım ve modelleri sonunda önerilen, BSN Davranış Modeli (Bireysel, Sosyal ve Normatif Davranış Modeli) sadece bu çalışma kapsamında analiz edilen teoriler ile sınırlı olup bu çalışmanın kısıtını oluşturmaktadır. Ayrıca teorik olarak önerilen bu modelin doğruluğunun ampirik olarak sınanması gerekmektedir.

\section{Kaynakça/References}

Ajzen, I. (2005). Attitudes, personality, and behavior. Poland: Open University Press.

Ajzen, I. (1991). The theory of planned behavior. Organizational behavior and human decision processes, 50(2), 179-211. 
Ajzen, I., ve Fishbein, M. (1980). Understanding attitudes and predicting social behavior, Prentice Hall.

Allison, B. J., Voss, R. S., ve Dryer, S. (2001). Student classroom and career success: The role of organizational citizenship behavior. Journal of Education for Business, 76(5), 282-288.

Ayyıldız-Ünnü, N. A. (2014). Rasyonel Perspektif Işı̆̆ında Karar Verme Eylemi: Nitel Bir Analiz. Journal of Management and Economics Research (Yönetim ve Ekonomi Araştırmaları Dergisi), 24, 91-116.

Bandura, A. (1989). Human agency in social cognitive theory. American Psychologist, 44(9), 1175.

Bargh, J (1994). The Four Horsemen of Automaticity: awareness, intention, efficiency, and control in social cognition. In Wyer R and T Skrull (eds) Handbook of Social Cognition (2nd edition) Vol 1: Basic Processes. Hillsdale, NJ: Lawrence Erlbaum.

Batson, C. D., ve Shaw, L. L. (1991). Evidence for altruism: Toward a pluralism of prosocial motives. Psychological Inquiry, 2(2), 107-122.

Bem, D. (1972) Self-perception Theory. In Berkowitz, L (ed) Advances in Experimental Social Psychology 6, London: Academic Press, 1-62.

Berkowitz, L. (1972) Social norms, feelings and other factors affecting helping and altruism. In L. Berkowitz, Advances in Experimental Social Psychology 6, New York: Academic Press.

Blasi, A. (1980). Bridging moral cognition and moral action: A critical review of the literature. Psychological bulletin, 88(1), 1-45.

Blau, P. M. (1964). Justice in social exchange. Sociological Inquiry, 34(2), 193-206.

Boiral, O. (2009). Greening the corporation through organizational citizenship behaviors. Journal of Business Ethics, 87, 221-236.

Boiral, O. ve Paillé, P. (2012). Organizational citizenship behaviour for the environment: Measurement and validation. Journal of Business Ethics, 109, 431-445.

Bourdieu, P. (1990). In other words: Essays towards a reflexive sociology. California: Stanford University Press.

Brief, A. P., ve Motowidlo, S. J. (1986). Prosocial organizational behaviors. Academy of management Review, 11(4), 710-725.

Buhrmester, D., Goldfarb, J., ve Cantrell, D. (1992). Self-presentation when sharing with friends and nonfriends. The Journal of Early Adolescence, 12(1), 61-79.

Carlo, G., Eisenberg, N., Troyer, D., Switzer, G., ve Speer, A. L. (1991). The altruistic personality: In what contexts is it apparent?. Journal of Personality and Social Psychology, 61(3), 450-458

Carlo, G., Hausmann, A., Christiansen, S., ve Randall, B. A. (2003). Sociocognitive and behavioral correlates of a measure of prosocial tendencies for adolescents. The Journal of Early Adolescence, 23(1), 107-134.

Carlo, G., ve Randall, B. A. (2002). The development of a measure of prosocial behaviors for late adolescents. Journal of Youth and Adolescence, 31(1), 31-44.

Cialdini, R. B. (2003). Crafting normative messages to protect the environment. Current Directions in Psychological Science, 12, 105-109.

Cialdini, R. B., Kallgren, C. A., ve Reno, R. R. (1991). A focus theory of normative conduct: A theoretical refinement and reevaluation of the role of norms in human behavior. In Advances in experimental social psychology (Vol. 24, pp. 201-234). Academic Press. 
Cialdini, R. B., Reno, R. R., ve Kallgren, C. A. (1990). A focus theory of normative conduct: Recycling the concept of norms to reduce littering in public places. Journal of Personality and Social Psychology, 58(6), 1015.

Colby, A., ve Kohlberg, L. (1987). The measurement of moral judgement: Theoretical foundations and research validation. Vol:1, New York: CambridgeUniversity Press.

Çalışkan, K. (2016). Siyasal kültür: Yeni yaklaşımlara genel bir bakış, Marmara Üniversitesi Siyasal Bilimler Dergisi, 4(2), pp 23-46.

Deluga, R. J. (1994). Supervisor trust building, leader $\square$ member exchange and organizational citizenship behaviour. Journal of occupational and Organizational Psychology, 67(4), 315-326.

Doran, R., ve Larsen, S. (2016). The relative importance of social and personal norms in explaining intentions to choose eco $\square$ friendly travel options. International Journal of Tourism Research, 18(2), 159-166.

Douglas, Mary 1997. In Defence of Shopping, In Falk, Pasi and Colin Campbell (eds) The Shopping Experience, London: Sage, 15-30.

Dunlap, R. E., Van Liere, K. D., Mertig, A. G., ve Jones, R. E. (2000). New trends in measuring environmental attitudes: measuring endorsement of the new ecological paradigm: A revised NEP scale. Journal of Social Issues, 56(3), 425-442.

Eisenberg B.N., Cameron, E., Tryon, K., ve Dodez, R. (1981). Socialization of prosocial behavior in the preschool classroom. Developmental Psychology, 17(6), 773.

Elliott, R., ve Wattanasuwan, K. (1998). Consumption and the Symbolic Project of the Self. ACR European Advances.

Elster, J. (Ed.). (1986). Rational choice. Chicago: NYU Press.

Eroğlu, Feyzullah. Davranış bilimleri. İstanbul: Beta Basım Yayım Dağıtım.

Etzioni, A. (1999). Normative-affective factors: Toward a new decision-making model. In A Etzioni (eds) Essays in Socio-Economics (pp. 91-119). Berlin Heidelberg: Springer.

Etzioni, A. (2010). Moral dimension: Toward a new economics. Cambridge: Simon and Schuster Press (1988 yılında yayınlanan kitabın tekrar basılmış şeklidir).

Fabes, R. A., ve Eisenberg, N. (1998). Meta-analyses of age and sex differences in children's and adolescents' prosocial behavior. Handbook of Child Psychology, 3, 1-29.

Ferrell, O. C., ve Skinner, S. J. (1988). Ethical behavior and bureaucratic structure in marketing research organizations. Journal of Marketing Research, 103-109.

Festinger, L 1957. A Theory of Cognitive Dissonance, California: Stanford University Press.

Fishbein, Martin 1973. The prediction of behaviour from attitudinal variables. In Mortensen, C and K Sereno (eds) Advances in Communications Research. New York: Harper and Row, 3-31.

Forsyth, D. R. (1992). Judging the morality of business practices: The influence of personal moral philosophies. Journal of Business Ethics, 11(5-6), 461-470.

Franzoi, S. L., Davis, M. H., ve Vasquez-Suson, K. A. (1994). Two social worlds: Social correlates and stability of adolescent status groups. Journal of Personality and Social Psychology, 67(3), 462-473.

Giddens, A 1979. Central Problems in Social Theory. Cambridge: Polity Press.

Giddens, A 1984. The Constitution of Society - outline of the theory of structuration. Berkeley and Los Angeles: University of California Press. 
Gollwitzer, P. M., Wicklund, R. A., ve Hilton, J. L. (1982). Admission of failure and symbolic selfcompletion: Extending Lewinian theory. Journal of Personality and Social Psychology, 43(2), 358-371.

Gorden, W. I. (1988). Range of employee voice. Employee Responsibilities and Rights Journal, 1(4), 283-299.

Gronovetter,M.(1985).Economic action and social structure: theproblemofembeddedness.American Sociological Review, 91, 481-510.

Gutman, J. (1982). A means-end chain model based on consumer categorization processes. The Journal of Marketing, 46(2), 60-72.

Hamilton, C. (2003). Growth Fetish. London and Melbourne: Berg Publishers.

Higgins, T. (1987). Self-discrepancy: A theory relating self to affect. Psychological Review 94, 319-340.

Hirschman, A. O. (1970). Exit, voice, and loyalty: Responses to decline in firms, organizations, and states (Vol. 25). Cambridge: Harvard University Press.

Hoffman, M. L. (1991). Empathy, social cognition, and moral action. In William L. Kurtines, Jack L. Gewirtz: Handbook of moral behavior and development, New York :Psychology Press, 275-301.

Homans G.C. (1961) Social Behavior: Its Elementary Forms, New York: Harcourt

Jackson, T. (2005). Motivating sustainable consumption. Sustainable Development Research Network, 29, 1-135.

Jager, W. (2003) Breaking Bad Habits: A dynamical perspective on habit formation and change, in L Hendrick, Wander Jager, L Steg (eds), Human Decision- Making and Environmental Perception - Understanding and Assisting Human Decision-Making in Real Life Settings. Libor Amicorum for Charles Vlek, Groningen: University of Groningen.

Johnson, M. ve Hasher L. (1987). Human learning and memory. Annual Review of Psychology, 38, 631-668.

Jones, J. W. (1989). Personality and epistemology: Cognitive social learning theory as a philosophy of science. Zygon, 24(1), 23-38.

Kahneman, D. ve Treisman A. (1984) Changing views of attention and automaticity. In R Parasuraman (ed) Varieties of Attention. New York: Academic Press.

Kleiser, S. B., Sivadas, E., Kellaris, J. J., ve Dahlstrom, R. F. (2003). Ethical ideologies: Efficient assessment and influence on ethical judgments of marketing practices. Psychology \& Marketing, $20(1), 1-21$.

Koçel, T. (2010). İşletme Yöneticiliği, İstanbul: Beta Basım..

Krebs, D. (1982). Prosocial behavior, equity, and justice. In J. Greenberg ve R.L. Cohen (eds) Equity and Justice in Social Behavior (pp. 261-308), New York: Academic Press.

Lamm, E., Tosti-Kharas, J., ve Williams, E.G. (2013). Read this article, but don't print it: Organizational citizenship behavior toward the environment. Group \& Organization Management, 38(2), 163-197.

Lancaster, K. J. (1966). A new approach to consumer theory. Journal of Political Economy, 74(2), $132-157$.

Leary, M. R., Knight, P.D., veBarnes, B. D. (1986)Ethical ideologies of the Machiavellian.Personality and Social Psychology Bulletin, 12(1), 75-80. 
Lewin, K. (1951). Field theory in social science, in D.Cartwright(eds) Selected theoretical papers. New York: Harper \& Row.

Lindenberg, S. (2001). Social rationality versus rational egoism. In J. Turner (Ed.), Handbook of Sociological Theory (pp. 635-668). New York: Kluwer Academic/Plenum.

Lindenberg, S., ve Steg, L. (2007). Normative, gain and hedonic goal frames guiding environmental behavior. Journal of Social Issues, 63(1), 117-137.

Logan, G. ve Cowan W. (1984) On the Ability to Inhibit Thought and Action: a theory of an act of control. Psychological Review 91, 295-327.

Luthans, F., ve Kreitner, R. (1985). Organizational Behaviour Modification and Beyond: An Operant and Social Learning Approach. Glenview, IL: Scott, Foresman.

Madden, T. J., Ellen, P. S., ve Ajzen, I. (1992). A comparison of the theory of planned behavior and the theory of reasoned action. Personality and Social Psychology Bulletin, 18(1), 3-9.

Manetti, L., Pierro, A., ve Livi, S. (2004). Recycling: Planned and self-expressive behaviour. Journal of Environmental Psychology, 24, 227-236.

Matthews, K. A., Batson, C. D., Horn, J., ve Rosenman, R. H. (1981). Principles in his nature which interest him in the fortune of others: The heritability of empathic concern for others. Journal of Personality, 49(3), 237-247.

McShane S.L. and Van Glinov M.A. (2016) Örgütsel Davranış (Çeviren: Ayşe Günsel and Serdar Bozkurt - 2. Basımdan Çeviri), İstanbul: Nobel Yayınevi.

Mead, G. (1934) Mind Self and Society. Chicago: University of Chicago Press.

Mendeş-Pekdemir, I., ve Turan, A. (2014). The mediating role of organizational identity complexity/ congruence on the relationship between perceived organizational prestige and in-role/extra-role performance. International Journal of Business and Social Science, 5(9-1), 119-131.

Monin, B., Pizarro, D.A., ve Beer, J.S. (2007). Deciding versus reacting: Conceptions of moral judgment and the reason-affect debate. Review of General Psychology, 11(2), 99-111.

Myers D.G. (2015) Sosyal Psikoloji (Social Psychology'den çeviren: Serap Akfirat), İstanbul: Nobel Yayınevi

Offermans, A. G. E. (2010). History of Cultural Theory; A summary of historical developments regarding Cultural Theory. Maastricht, ICIS Report.

Ones, D. S., and Dilchert, S. (2012). Employee green behaviors. In S. E. Jackson, D. S. Ones, and S. Dilchert (Eds.), Managing HR for environmental sustainability (pp. 155-186). San Francisco: Jossey-Bass/Wiley.

Onwezen, M. C., Antonides, G., ve Bartels, J. (2013). The Norm Activation Model: An exploration of the functions of anticipated pride and guilt in pro-environmental behaviour. Journal of Economic Psychology, 39, 141-153.

Organ, D. W. (1990). The motivational basis of organizational citizenship behavior. Research in Organizational Behavior, 12(1), 43-72.

Öcal H. ve Sarnıç, A. (2017). Dönüştürücü Liderliğin Prososyal Örgütsel Davraniş Üzerindeki Etkileri ve İmalat Endüstrisinde Bir Araştirma. Afyon Kocatepe Üniversitesi İktisadi ve İdari Bilimler Fakültesi Dergisi, 19(2), 107-125.

Ölander, F. and Thøgersen J. (1995) Understanding Consumer Behaviour as Prerequisite for Environmental Protection. Journal of Consumer Policy 18, 345-385. 
Parker, S. K., Collins, C. G., ve Grant, A. M. (2008). The role of positive affect in making things happen. In Annual SIOP Conference, San Francisco, USA.

Pavlov, I. P. (1941). Lectures on Conditioned Reflexes. Vol. II. Conditioned reflexes and psychiatry, New York: International Publishers (http://psycnet.apa.org/record/1941-04246-000)

Pavlov, P. I. (2010). Conditioned reflexes: an investigation of the physiological activity of the cerebral cortex. Annals of Neurosciences, 17(3), 136. (1927 yazılan makalenin çevirisidir.)

Podsakoff, P.M., ve MacKenzie, S.B. (1994). An examination of the psychometric properties and nomological validity of some revised and reduced substitutes for leadership scales. Journal of Applied Psychology, 79(5), 702.

Podsakoff, P. M., MacKenzie, S. B., Paine, J. B., ve Bachrach, D. G. (2000). Organizational citizenship behaviors: A critical review of the theoretical and empirical literature and suggestions for future research. Journal of Management, 26(3), 513-563.

Polanyi, K., ve MacIver, R. M. (1944). The great transformation(Vol. 2). Boston: Beacon Press.

Reckwitz, A. (2002). The status of the "material" in theories of culture: From "social structure" to "artefacts". Journal for the theory of social Behaviour, 32(2), 195-217.

Rest, J. R. (1983). Morality. Handbook of child psychology, 3, 556-629.

Reynolds, T. J., ve Gutman, J. (1988). Laddering theory, method, analysis, and interpretation. Journal of Advertising Research, 28(1), 11-31.

Robbins S.P. and Judge T.A. (2013) Örgütsel Davranış - Organizational Behavior (Çeviren: İnci Erdem, 14.Basımdan çeviri), İstanbul: Nobel Yayınevi.

Roccas, S., ve Brewer, M. B. (2002). Social identity complexity. Personality and Social Psychology Review, 6(2), 88-106.

Rokeach, M. (1973). The nature of human values. New York: Free press.

Ruepert A.M., Steg L. ve Keizer K. (2015) The Nature an Umbrella and Multifacet Concept, In J.L. Robertson ve J. Barling (Eds) The Psychology of Green Organizational Behavior, New York: Oxford Press, s. 12-32.

Russell, B. (2000) A History of Western Philosophy, London: Routledge.

Scherbaum, C. A., Popovich, P. M., ve Finlinson, S. (2008). Exploring individual-level factors related to employee energy-conservation behaviors at work. Journal of Applied Social Psychology, 38, 818-835.

Schnake, M. E., ve Dumler, M. P. (2003). Levels of measurement and analysis issues in organizational citizenship behaviour research. Journal of occupational and organizational psychology, 76(3), 283-301.

Schultz, W. P. (2001). The structure of environmental concern: concern for self, other people, and the biosphere. Journal of Environmental Psychology, 21, 327-339.

Schultz, D. P., ve Schultz, S. E. (2001). Modern Psikoloji Tarihi, çev. Yasemin Aslay, Kaknüs Yayınları, İstanbul.

Schwartz, S. H. (1973). Normative explanations of helping behavior: A critique, proposal, and empirical test. Journal of Experimental Social Psychology, 9(4), 349-364.

Schwartz, S. H. (1977). Normative influences on altruism. In L. Berkowitz (eds) Advances in experimental social psychology (Vol. 10, pp. 221-279). Academic Press. 
Schwartz, S. H. (1992). Universals in the content and structure of values: Theoretical advances and empirical tests in 20 countries. In M.P. Zanna (eds) Advances in experimental social psychology (Vol. 25, pp. 1-65). Academic Press.

Schwartz, S. H. (1994). Are there universal aspects in the structure and contents of human values? Journal of social issues, 50(4), 19-45.

Schwartz, S. H., ve Howard, J. A. (1984). A Normative Decision-Making Model of Altruism. in JP Rushton,. \& RM Sorrentino (Ed.) Altruism and Helping Behavior Social, Personality, and Development a Perspective (p.189-211). Nilsdale: NJ:Erlbaum.

Sen, A. (1984) The Living Standard, Oxford Economic Papers 36, 74-90.

Simon, H. (1957). Models of Man, New York: JohnWiley.

Skinner, B. F. (1948). 'Superstition'in the pigeon. Journal of Experimental Psychology, 38(2), 168.

Sorrentino, R. M., ve Rushton, IJ. P. (1981) Altruism and helping behavior: Current perspectives and future possibilities. In J. P. Rushton ve R. M. Sorrentino (Eds.), Altruism and helping behavior: Social, personality, and developmental perspectives (pp. 425-439). Hillsdale, NJ: Erlbaum

Staub, E. (1978). Positive social behavior and morality: Social and personal influences, New York: Academic Press.

Stead, W. E., Worrell, D. L., ve Stead, J. G. (1990). An integrative model for understanding and managing ethical behavior in business organizations. Journal of Business Ethics, 9(3), 233-242.

Steg, L., Bolderdijk, J. W., Keizer, K., ve Perlaviciute, G. (2014). An integrated framework for encouraging pro-environmental behaviour: The role of values, situational factors and goals. Journal of Environmental Psychology, 38, 104-115.

Steg, L., ve De Groot, J. (2010). Explaining prosocial intentions: Testing causal relationships in the norm activation model. British Journal of Social Psychology, 49, 725-743

Stern, P. (2000). Toward a coherent theory of environmentally significant behavior. Journal of Social Issues, 56(3), 407-424.

Stern, P. C., ve Dietz, T. (1994). The value basis of environmental concern. Journal of social issues, 50(3), 65-84.

Stern, P. C., Dietz, T., Abel, T., Guagnano, G. A., ve Kalof, L. (1999). A value-belief-norm theory of support for social movements: The case of environmentalism. Human Ecology Review, 6(2), 81-97.

Şimşek M.Ş., Çelik A. ve Akgemci T. (2015) Davranış bilimlerine giriş ve örgütlerde davranış, Konya: Eğitim Yayınevi (9.Bask1).

Tabernero, C., ve Hernández, B. (2011). Self-efficacy and intrinsic motivation guiding environmental behavior. Environment and Behavior, 43(5), 658-675.

Tajfel, H. (1982) Social Identity and Intergroup Relations. Cambridge: Cambridge University Press.

Tajfel, H. ve Turner J. (1979) An Integrative Theory of Inter-Group Conflict. In Austin, W and S Worchel (eds) The Social Psychology of Intergroup Relations. Monterey,CA: Brooks/Cole, 3347.

Taylor, P. W. (1975). Principles of ethics: An introduction. (The Dickenson series in philosophy):Wadsworth Pub.

Thibaut, J. ve Kelley, H. H. (1959). The Social Psychology of Groups. New York: Wiley 
Thompson, M., Ellis, R., ve Wildavsky, A. (1990). Political cultures. Oxford:West View.

Thompson, M. (2018). Cultural theory. New York: Routledge.

Tolman, E. C. (1951). Purposive behavior in animals and men. California: Univ of California Press.

Tudor, T. L., Barr, S. W., ve Gilg, A. W. (2007). A tale of two locational settings: Is there a link between pro-environmental behavior at work and at home? Local Environment: The International Journal of Justice and Sustainability, 12, 409-421

Turan, A. (2015). Satisfaction with Organization and Intention to Retain: The Mediating Role of Organizational Identity Complexity/Congruence of Outsourcing Labors. The Anthropologist, 21(1-2), 300-310.

Treviño, L. K., Weaver, G. R., ve Reynolds, S. J. (2006). Behavioral ethics in organizations: A review. Journal of management, 32(6), 951-990.

Triandis, Harry 1977. Interpersonal Behaviour. Monterey, CA: Brooks/Cole.

Tversky, A., ve Kahneman, D. (1974). Judgment under uncertainty: Heuristics and biases. Science, 185(4157), 1124-1131.

Unsworth, K. L., Dmitrieva, A., and Adriasola, E. (2013). Changing behaviour: Increasing the effectiveness of workplace interventions in creating pro $\square$ environmental behaviour change. Journal of Organizational Behavior, 34(2), 211-229.

Walster, E. ve Piliavin, J.A. (1972) Equity and the Innocent Bystander1. Journal of Social Issues, 28(3), 165-189.

Watson,J.B. ve Meazzini,P. (1977) .John B. Watson (http://self.gutenberg.org/articles/john_b._ watson)

Wicklund, R. ve Gollwitzer P. (1982) Symbolic Self-Completion, Hillsdale, NJ: Erlbaum.

Wright, R. (1994) The Moral Animal - Why we are the way we are: The new science of evolutionary psychology. London: Abacus.

Wolfson, S. L. (1981). Effects of Machiavellianism and communication on helping behaviour during an emergency. British Journal of Social Psychology, 20(3), 189-195.

Van der Werff, E., Steg, L., ve Keizer, K. (2013). The value of environmental self-identity: The relationship between biospheric values, environmental self-identity and pro-environmental preferences, intentions and behaviour. Journal of Environmental Psychology, 34, 55-63.

Van Dyne, L., ve LePine, J. A. (1998). Helping and voice extra-role behaviors: Evidence of construct and predictive validity. Academy of Management journal, 41(1), 108-119.

Van Dyne, L., Cummings, L. L., ve Parks, J. M. (1995). Extra-role behaviors-in pursuit of construct and definitional clarity (a bridge over muddied waters). Research in Organizational Behavior: An Annual Series of Analytical Essays and Critical Reviews, 17, 215-285.

Zey, M. (1992). Criticisms of rational choice models. Thousand Oaks, CA: Sage Publications. 